IDAHO NATIONAL ENGINEERING LABORATORY

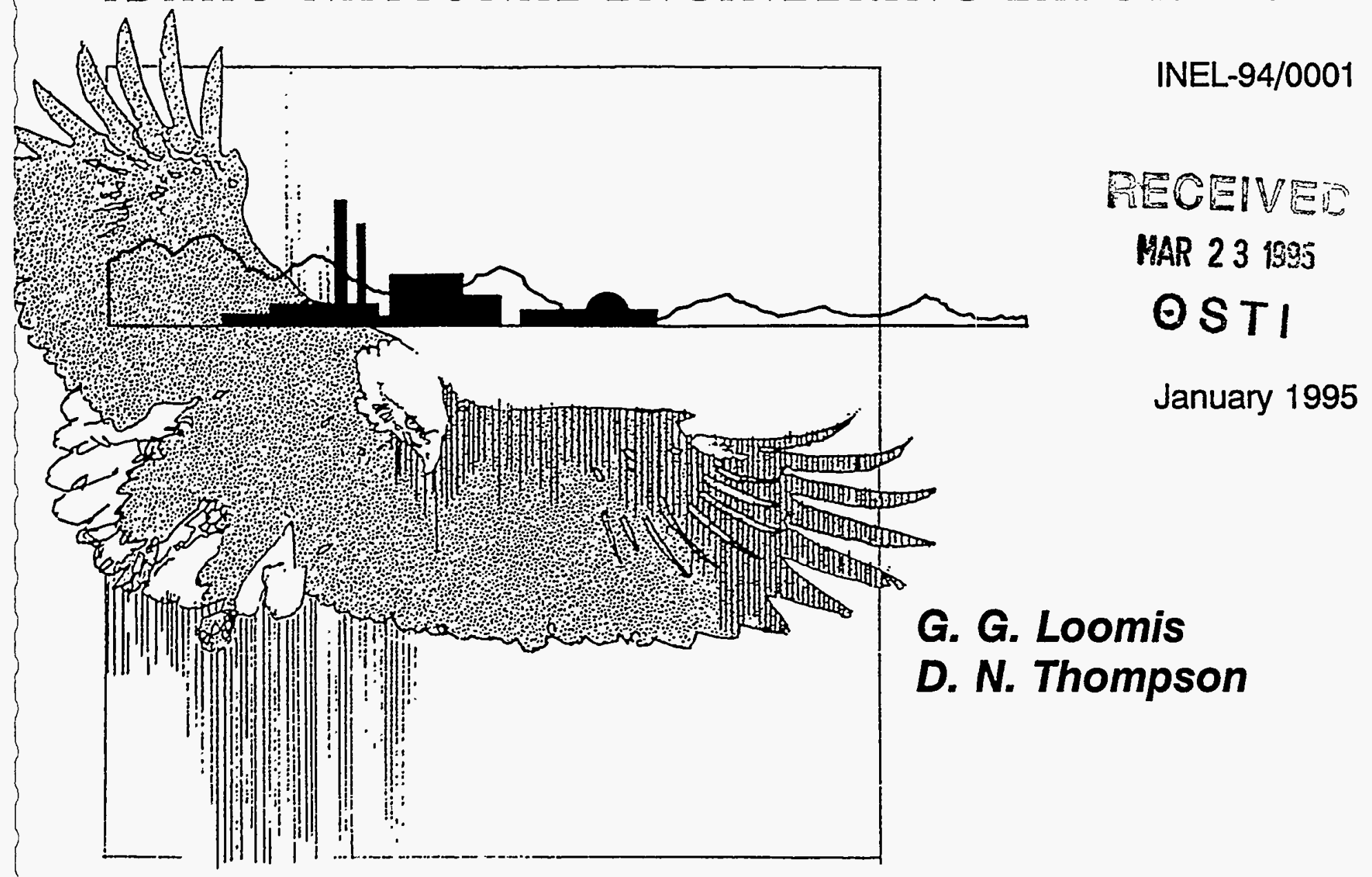

\title{
Innovative Grout/Retrieval Demonstration Final Report
}




\section{DISCLAIMER}

This report was prepared as an account of work sponsored by an agency of the United States Government. Neither the United States Government nor any agency thereof, nor any of their employees, makes any warranty, express or implied, or assumes any legal liability or responsibility for the accuracy, completeness, or usefulness of any infomation, apparatus, product or process disclosed, or represents that its use would not infringe privately owned rights. Peferences herein to any specific commercial product, process, or service by trade name, trademark, manufacturer, or otherwise, does not necessarily constitute or imply its endorsement, recommendation, or favoring by the United States Government or any agency thereof. The views and opinions of authors expressed herein do not necessarily state or reflect those of the United States Government or any agency thereof. 


\section{DISCLAIMER}

Portions of this document may be illegible in electronic image products. Images are produced from the best available original document. 


\title{
Innovative Grout/Retrieval Demonstration Final Report
}

\author{
G. G. Loomis \\ D. N. Thompson
}

Published January 1995

\section{Idaho National Engineering Laboratory Lockheed Idaho Technologies Company Idaho Falls, Idaho 83415}

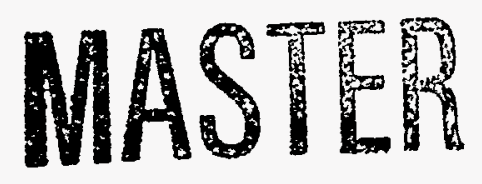

Prepared for the

U.S. Department of Energy

Office of Environmental Management

Under DOE Idaho Operatlons Office

Contract DE-AC07-941D13223 
Innovative Grout/Retrieval Demonstration Final Report

INEL-94/0001

Prepared by

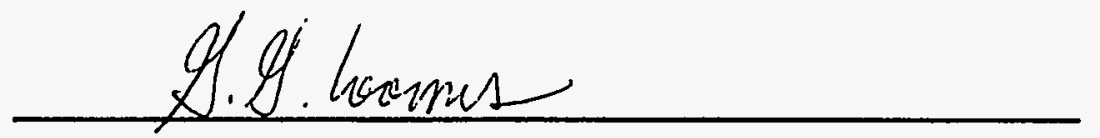

G. G. Loomis, S\&E Project Manager Buried Waste Integrated Demonstration

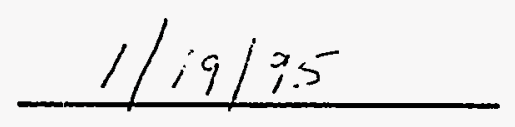

Date

Reviewed by

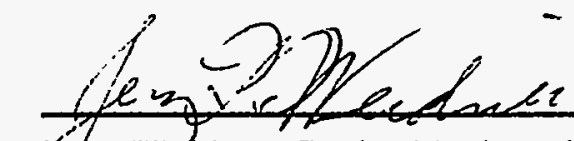

J.R. Weidner, Senior Engineering Specialist

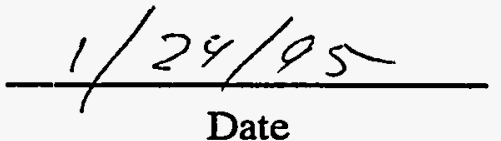

Approved by

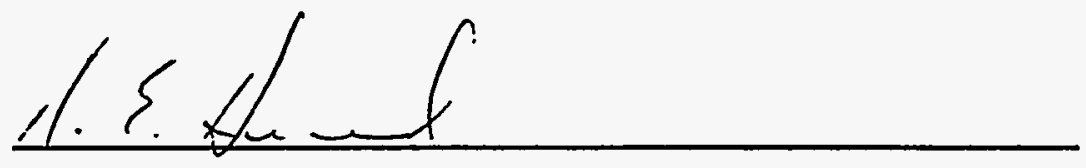

R. E. Heard, S\&E Project Manager

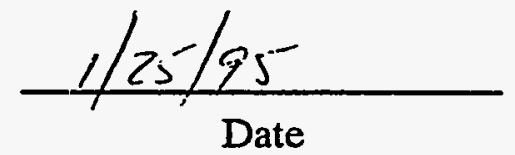

Buried Waste Integrated Demonstration 


\begin{abstract}
This report presents the results of an evaluation of an innovative retrieval technique for buried transuranic waste. Application of this retrieval technique was originally designed for full pit retrieval; however, it applies equally to a hot spot retrieval technology. The technique involves grouting the buried soil waste matrix with a jet grouting procedure, applying an expansive demolition grout to the matrix, and retrieving the debris. The grouted matrix provides an agglomeration of fine soil particles and contaminants resulting in an inherent contamination control during the dusty retrieval process. A full-scale field demonstration of this retrieval technique was performed on a simulated waste pit at the Idaho National Engineering Laboratory. Details are reported on all phases of this proof-of-concept demonstration including pit construction, jet grouting activities, application of the demolition grout, and actual retrieval of the grouted pit. A quantitative evaluation of aerosolized soils and rare earth tracer spread is given for all phases of the demonstration, and these results are compared to a baseline retrieval activity using conventional retrieval means.
\end{abstract}




\section{SUMMARY}

During the summer of 1994, a demonstration of an innovative retrieval technology was performed at the Idaho National Engineering Laboratory (INEL) by the Buried Waste Integrated Demonstration for the U.S. Department of Energy's Office of Technology Development. This report presents the results of that demonstration, makes conclusions, and offers recommendations on the proof of concept for the technology. The technology involves grouting the buried waste using a jet grouting technique. Following curing of the resulting monolith, a demolition grout is applied to fracture the waste into easily retrievable pieces. Finally, the fractured debris is retrieved using remotely controlled retrieval equipment. The technology offers an inherent contamination control in that the contaminants and soil particles are agglomerated into a soilcrete mixture that is not easily aerosolized. State-of-the art contamination control strategies presently use water sprays, fixant systems, and dust suppressants involving complicated deployment while this grouting/retrieval strategy offers enhanced contamination control. Results of the demonstration are provided below.

A simulated waste pit, $10 \times 10 \times 10 \mathrm{ft}$, was constructed using 55-gal cardboard and steel drums and $4 \times 4 \times 4$-ft cardboard boxes full of simulated waste. Each container had a random dump of $200 \mathrm{~g}$ of rare earth tracer to simulate a worst case loading of the transuranic contaminant. The pit was built prototypical of pits found in the INEL's Subsurface Disposal Area using backfilled lakebed soil. A large weather shield was erected over the site and air samplers were used for all major portions of the demonstration. The first phase involved the jet grouting using the CASA GRANDE jet grouting apparatus. The second phase involved application of demolition grout. The third phase involved using a standard backhoe with thumb attachment to retrieve the waste.

The jet grouting phase was accomplished with minimal dust spread and no rare earth tracer spread above background. A total of 36 grout holes emplaced $24 \mathrm{yd}^{3}$ of Portland cement into the pit in a jet grouting action (at nominally $6,000 \mathrm{psi}$ ). The jet grouting was accomplished by first driving the injection bit into the waste and withdrawing the bit in $5-\mathrm{cm}$ increments while applying a slow rotation of the bit. The withdrawal rate was nominally $5 \mathrm{~cm}$ per 6 seconds.

The hole spacing was 24 in. on a triangular basis and the process took about 40 minutes to drill and jet grout each hole. The hole spacing was based on a series of predemonstration field trials in compacted INEL soil in which up to 28-in. diameter soilcrete columns were created. After each jet grouting operation, a bottom sealed, 2-in. diameter spiral wrapped tube was placed into the drill hole and allowed to cure in place. During the jet grouting operation, soilcrete and some waste in the form of sludge came to the surface of the pit (in gallon quantities for some holes). Although this material contained the rare earth tracer, no airborne spread of the tracer was found above background on the air samplers spaced systematically around the pit.

The application of BRISTAR as a demolition grout failed to fracture the waste as planned. The reason the grout did not expand upon curing was due to a temperature gradient in the monolith with up to $60^{\circ} \mathrm{F}$ higher temperatures in the middle regions of the monolith than on the edges. This axial temperature gradient was caused by the heat of hydration as the Portland cement cured. The temperature was maintained by the surrounding insulating properties of the soil. As a result, it was difficult to match the correct BRISTAR product with the correct temperature to achieve fracturing. The grout appeared to expand at the near surface positions; however, these were the cooler positions. A separate application of the BRISTAR product in several holes drilled directly into the monolith 
produced fracturing. For this case, the temperature of the pit was more uniform and lower than the post grouting value. An alternative nondust producing technique to the demolition grout would have been to use a hydraulic rock splitter in the spiral wrapped tubes to fracture the monolith.

Although the monolith was not fractured by the demolition grout, the standard backhoe bucket with thumb attachment in the belowgrade orientation was successful in removing the monolith. The monolith was removed in just under 5 hours of retrieval time. Grouted boxes containing metal pipe, wire, and plate steel caused the most difficulty in retrieval, and a larger backhoe or front end loader would have greatly facilitated the process. The general soilcrete mix was easy to break off with the backhoe in $1 \times 2-\mathrm{ft}$ portions. One of the waste materials that caused the most tracer spread was computer paper (6-in. thick portions). Removal of computer paper resulted in tracer spread because the grout-encased paper easily disintegrated when retrieved, leaving the computer paper intact with visible tracer on the paper. Other waste forms such as pipes and wood also separated from the grout during retrieval; however, there was a layer of grout on the surface, and the pipes were completely filled. If the waste pit contained all intact metal drums, this process probably would result in completely grouted drums including the space between the drum and drum liner. One such specimen of a metal drum originally containing plastic pipe was completely full of grout and was sectioned for display purposes.

The retrieval was accomplished with both overburden in place and overburden removed, and it was found that leaving the overburden on promotes both dust and tracer spread during retrieval. Retrieval with the overburden in place resulted in dust removal over the baseline retrieval case of between 30 and $40 \%$, which compares unfavorably with conventional contamination control cases using misting and fixants where $70 \%$ dust removal was achieved. However, when performing retrieval with the overburden removed, a $90 \%$ dust removal was achieved. During retrieval with the overburden on, the airborne tracer concentration was 4,000 times background, and with the overburden removed, the tracer concentration was only 1.35 times background. The overburden fell into the pit displacing air, causing entrained particulate from the debris in the bottom of the pit to travel to the air monitors, which indicated contaminant spread.

An engineering estimate for applying this technology for radioactive applications was performed showing that the costs were not prohibitive. To perform grouting and retrieval on a 1-acre site would cost $\$ 12.4 \mathrm{M}$, excluding costs associated with containment and management of the project. To perform a hot spot removal on a $40 \times 60$-ft site would cost just over $\$ 3 \mathrm{M}$, again neglecting the costs associated with management and containment. For either of these estimates, there are no costs given for treatment and final disposal.

In summary, a positive proof-of-concept for a enhanced contamination control was shown during the demonstration. The technology could be applied to buried heterogeneous waste for hot spot retrieval or full pit retrieval and could also be applied to contaminated soil zones: It is recommended that the retrieval technology be further examined to obtain an efficient retrieval technique compatible with the grouting idea. For full-scale retrieval, this would involve a 40,000 pound mass class excavator or larger and a large Balderson thumb end effector with companion shears. For this large excavator approach, the abovegrade digging action would pull the waste into the bucket and keep the waste from falling into the pit causing spread of contaminants with dust. 


\section{CONTENTS}

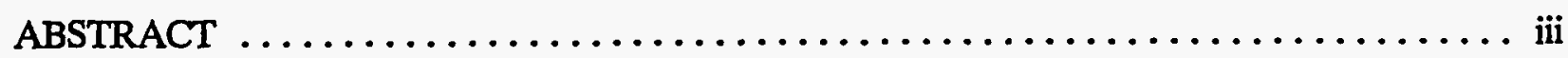

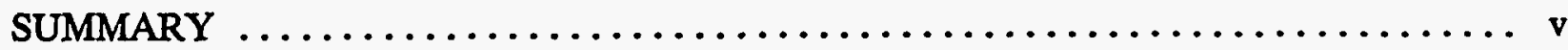

1. INTRODUCTION AND TECHNOLOGY DESCRIPTION $\ldots \ldots \ldots \ldots \ldots \ldots \ldots$

2. TEST OBJECTIVES $\ldots \ldots \ldots \ldots \ldots \ldots \ldots \ldots \ldots \ldots \ldots \ldots \ldots \ldots \ldots \ldots \ldots \ldots \ldots \ldots \ldots \ldots$

3. EXPERIMENTAL DESIGN AND PROCEDURES $\ldots \ldots \ldots \ldots \ldots \ldots \ldots \ldots$

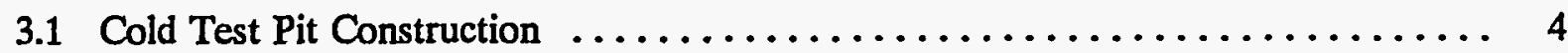

3.2 Weather Shield Construction $\ldots \ldots \ldots \ldots \ldots \ldots \ldots \ldots \ldots \ldots \ldots \ldots \ldots$

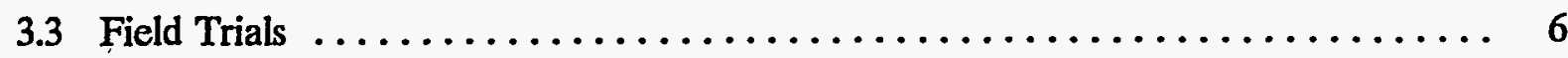

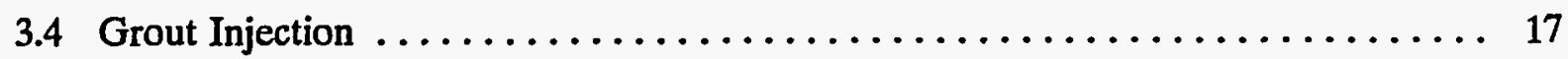

3.5 Demolition Grout Application $\ldots \ldots \ldots \ldots \ldots \ldots \ldots \ldots \ldots \ldots \ldots \ldots \ldots \ldots \ldots \ldots \ldots$

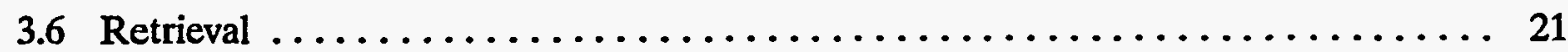

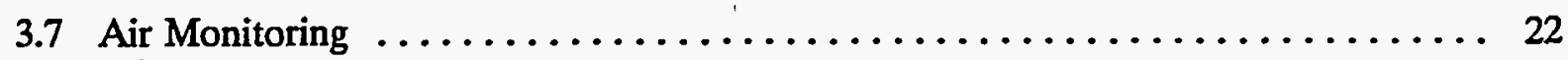

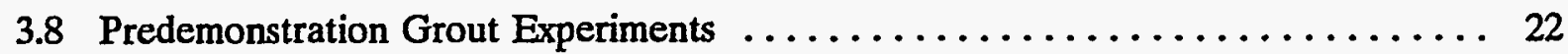

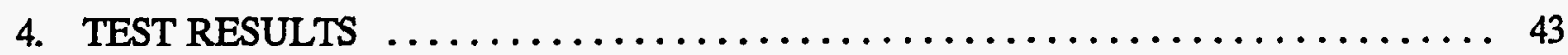

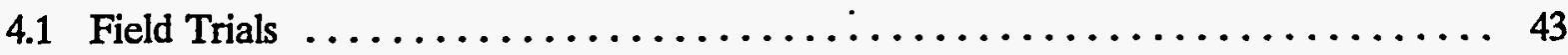

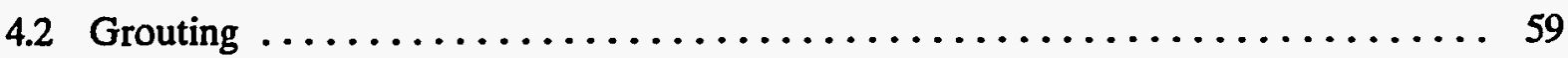

4.2.1 Grouting Efficiency $\ldots \ldots \ldots \ldots \ldots \ldots \ldots \ldots \ldots \ldots \ldots \ldots \ldots \ldots$

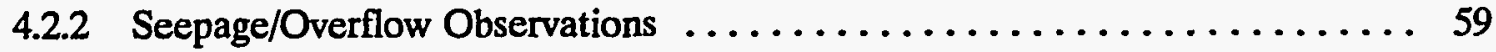

4.2.3 Volume Increase in the Pit During Grouting $\ldots \ldots \ldots \ldots \ldots \ldots \ldots 62$

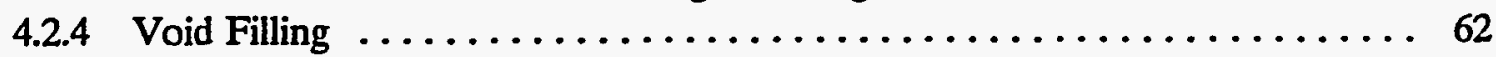

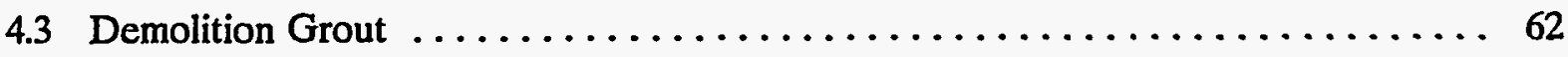

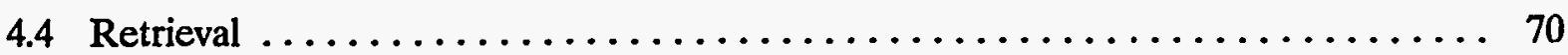

4.4.1 Monolith Characteristics .......................... 73

4.4.2 Efficiency of BRISTAR Demolition Grout ................ 87

4.4.3 Formation of "Shadows" and Incomplete Grouting $\ldots \ldots \ldots \ldots \ldots \ldots . . .88$ 
4.5 Dust Control/Contamination Control $\ldots \ldots \ldots \ldots \ldots \ldots \ldots \ldots \ldots \ldots$

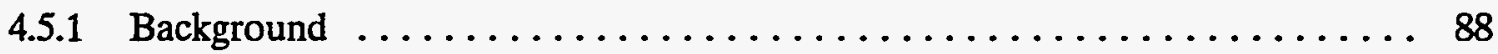

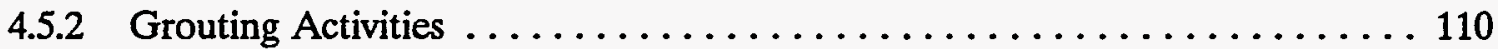

4.5.3 Retrieval ................................. 110

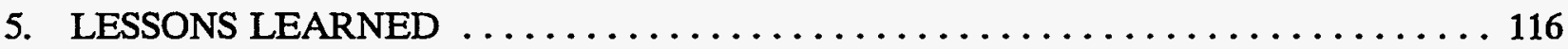

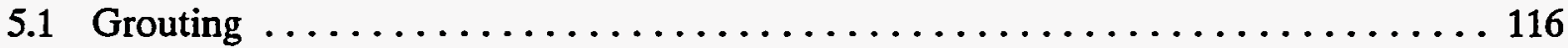

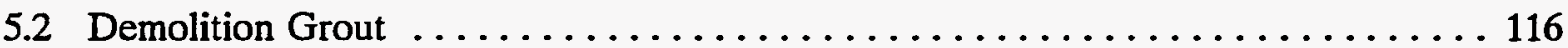

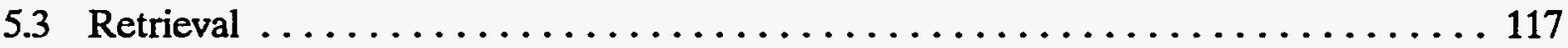

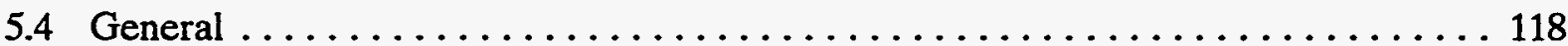

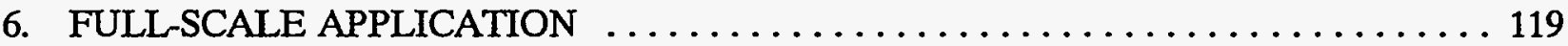

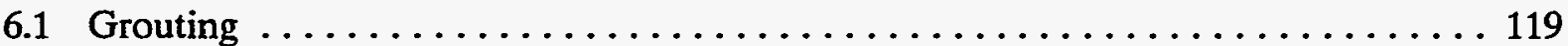

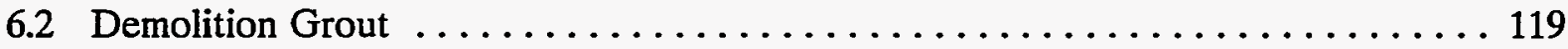

6.3 Retrieval ...................................... 119

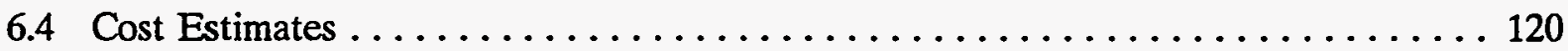

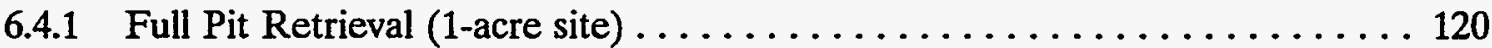

6.4 .2 Hot Spot Retrieval . . . . . . . . . . . . . . . . . . . . . 120

6.4.3 Alternative Hot Spot Retrieval ..................... 121

7. CONCLUSIONS AND RECOMMENDATIONS $\ldots \ldots \ldots \ldots \ldots \ldots \ldots \ldots \ldots \ldots \ldots$

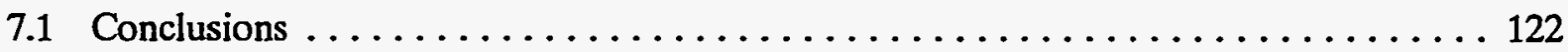

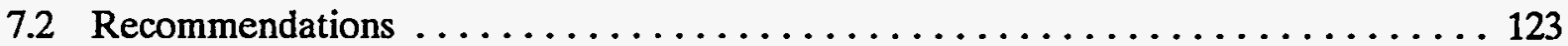

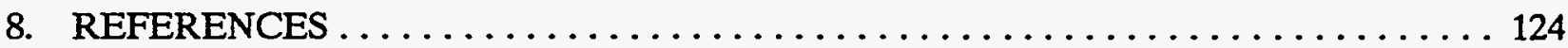

Appendix A-BRISTAR Grout Catalog $\ldots \ldots \ldots \ldots \ldots \ldots \ldots \ldots \ldots \ldots \ldots \ldots \ldots \ldots \ldots \ldots \ldots \ldots$

Appendix B-Results of Field Coring of In situ Grouted Samples $\ldots \ldots \ldots \ldots \ldots \ldots$ B-1

Appendix C-Data from Air Monitoring $\ldots \ldots \ldots \ldots \ldots \ldots \ldots \ldots \ldots \ldots \ldots \ldots \ldots \ldots \ldots \ldots \ldots$ 


\section{FIGURES}

1. Orientation of waste containers in the pit $\ldots \ldots \ldots \ldots \ldots \ldots \ldots \ldots \ldots \ldots \ldots \ldots$

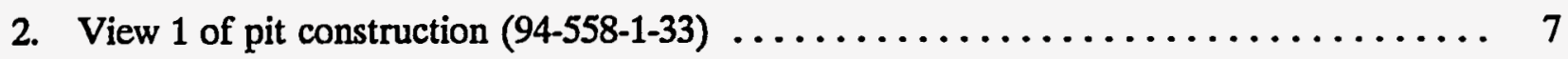

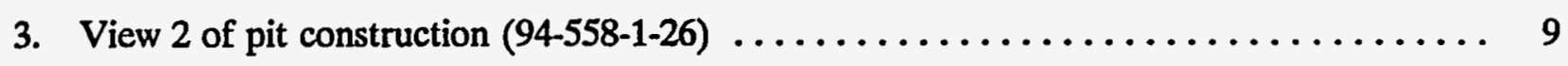

4. Weather shield for demonstration $(94-715-5-3) \ldots \ldots \ldots \ldots \ldots \ldots \ldots \ldots \ldots \ldots$

5. CASA GRANDE high pressure pump $(94-716-3-3) . \ldots \ldots \ldots \ldots \ldots \ldots \ldots \ldots$

6. CASA GRANDE drill system $(94-715-1-12) \ldots \ldots \ldots \ldots \ldots \ldots \ldots \ldots \ldots \ldots \ldots \ldots \ldots \ldots \ldots$

7. Final grid of grouted pit $\ldots \ldots \ldots \ldots \ldots \ldots \ldots \ldots \ldots \ldots \ldots \ldots \ldots \ldots \ldots \ldots \ldots \ldots \ldots \ldots \ldots$

8. Starting position for drilling into pit $(94-716-1-4) . \ldots \ldots \ldots \ldots \ldots \ldots \ldots \ldots \ldots$

9. Grouted pit with spiral wrapped tubes $(94-749-1-5) \ldots \ldots \ldots \ldots \ldots \ldots \ldots \ldots$

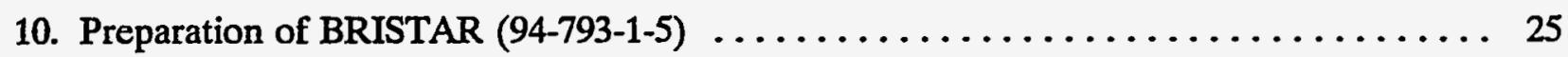

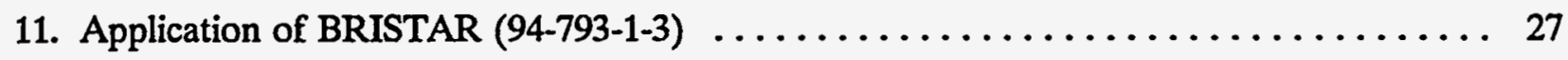

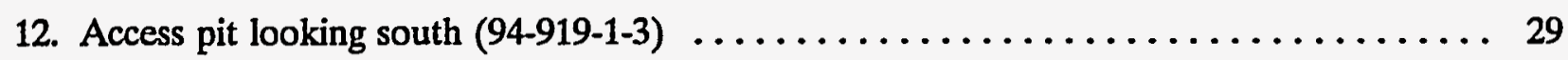

13. Access pit looking north $(94-919-1-5) \ldots \ldots \ldots \ldots \ldots \ldots \ldots \ldots \ldots \ldots \ldots \ldots \ldots \ldots$

14. Backhoe in digging position in access pit $(94-837-1-13) \ldots \ldots \ldots \ldots \ldots \ldots \ldots \ldots$

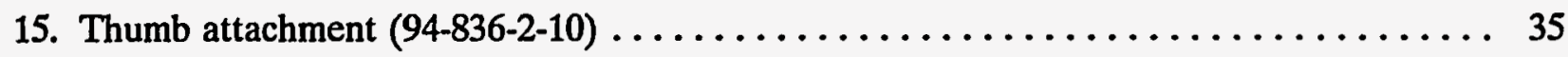

16. Technique for digging monolith $(94-836-1-4) \ldots \ldots \ldots \ldots \ldots \ldots \ldots \ldots \ldots \ldots$

17. High-volume air sampler $\ldots \ldots \ldots \ldots \ldots \ldots \ldots \ldots \ldots \ldots \ldots \ldots \ldots \ldots \ldots \ldots$

18. Orientation of samplers relative to pit $(94-714-1-13) \ldots \ldots \ldots \ldots \ldots \ldots \ldots \ldots \ldots$

19. Spacing and order of application for field trials $\ldots \ldots \ldots \ldots \ldots \ldots \ldots \ldots \ldots, 44$

20. Grout columns during field trials (scale is in inches) $(94-715-2-12) \ldots \ldots \ldots \ldots \ldots 45$

21. Detail of grout column 4 during field trials (scale is in inches) $(94-715-2-13) \ldots \ldots \ldots 47$

22. Drill stem hole in top of column 1 during field trials (scale is in inches) (94-715-4-5) . . . 49

23. Soilcrete column 5 during field trials (scale is in inches) $(94-715-5-9) \ldots \ldots \ldots \ldots \ldots 51$ 
24. Drill stem hole 3 with blocked injector during field trials (scale is in inches)

(94-715-2-1)

25. Fracture caused by BRISTAR in hole 3 during field trials (scale is in inches)

(94-715-2-5)

26. Expansion of BRISTAR tube during field trials (scale is in inches) (94-715-4-15) . . . . 57

27. Grout collection pit during grouting $(94-716-4-1) \ldots \ldots \ldots \ldots \ldots \ldots \ldots$

28. Grout/sludge emission from hole 6 during grouting of hole 2 (94-749-1-5) . . . . . . 65

29. Grout flowing through trenches to grout collection pit $(94-749-1-5) \ldots \ldots \ldots \ldots$

30. Blowout of BRISTAR during steam explosion $(94-793-2-3) \ldots \ldots \ldots \ldots \ldots \ldots \ldots$

31. Digging monolith (at top) $(94-786-2-14) \ldots \ldots \ldots \ldots \ldots \ldots \ldots \ldots \ldots$

32. Digging monolith (debris) $(94-836-1-3) \ldots \ldots \ldots \ldots \ldots \ldots \ldots \ldots \ldots$

33. Cross sectional view of grouted monolith and overburden $\ldots \ldots \ldots \ldots \ldots \ldots$

34. Grout hole/overburden/monolith during retrieval $(94-836-1-10) \ldots \ldots \ldots \ldots \ldots$

35. Piles of waste in access pit following backhoe operation on the monolith $(94-836-1-6) \ldots \ldots \ldots \ldots \ldots \ldots \ldots \ldots \ldots \ldots \ldots \ldots \ldots \ldots \ldots \ldots \ldots$

36. General view of exposed monolith $(94-836-1-1) \ldots \ldots \ldots \ldots \ldots \ldots \ldots$

37. View 1 of monolith in sunlight $(94-1180-1-22) \ldots \ldots \ldots \ldots \ldots \ldots \ldots \ldots$

38. View 2 of monolith in sunlight $(94-1180-1-4) \ldots \ldots \ldots \ldots \ldots \ldots \ldots \ldots \ldots$

39. View 3 of monolith in sunlight $(94-1180-1-6) \ldots \ldots \ldots \ldots \ldots \ldots \ldots \ldots \ldots$

40. Rim of drum locked into grouted monolith $(94-836-2-8) \ldots \ldots \ldots \ldots \ldots$

41. Drum just removed from monolith $(94-836-2-10) \ldots \ldots \ldots \ldots \ldots \ldots \ldots$

42. Gross sectional view of grouted drum (jet grouted $10-\mathrm{ft}$ below surface)

(94-913-2-28) . . . . . . . . . . . . . . . . . . . . . . . . . . 99

43. Detail of grouted drum showing spiral wrapped tube $(94-913-2-29) \ldots \ldots \ldots \ldots 1$

44. Several waste materials retrieved from monolith $(94-1180-1-14) \ldots \ldots \ldots \ldots \ldots$

45. View 1 of fracturing of monolith with BRISTAR (special) $(94-1180-1-2) \ldots \ldots \ldots$. . . 105 
46. View 2 of fracturing of monolith with BRISTAR (special) $(94-1180-1-9) \ldots \ldots \ldots \ldots 107$

47. Orientation of "small tent" for final retrieval $(\mathrm{R}-5) \ldots \ldots \ldots \ldots \ldots \ldots \ldots \ldots \ldots \ldots \ldots \ldots \ldots$

\section{TABLES}

1. Cold test pit waste materials $\ldots \ldots \ldots \ldots \ldots \ldots \ldots \ldots \ldots \ldots \ldots \ldots \ldots \ldots \ldots$

2. Field trail jet grouting data $\ldots \ldots \ldots \ldots \ldots \ldots \ldots \ldots \ldots \ldots \ldots \ldots \ldots \ldots \ldots \ldots \ldots$

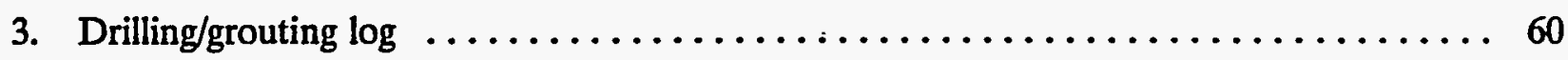

4. Contact temperature history of the bottom pit $\ldots \ldots \ldots \ldots \ldots \ldots \ldots \ldots \ldots \ldots$

5. Temperature of mid point on the monolith using a digital hanging thermocouple $\ldots \ldots$. 73

6. Retrieval operations for the innovative grout/retrieval demonstration $\ldots \ldots \ldots \ldots \ldots$. 74

7. Average tracer and dust concentration data $\ldots \ldots \ldots \ldots \ldots \ldots \ldots \ldots \ldots \ldots \ldots \ldots$

8. Cement-soil type and smear samples for praseodymium by ICP-MS $\ldots \ldots \ldots \ldots \ldots 111$

9. Summary of dust concentration during retrieval $\ldots \ldots \ldots \ldots \ldots \ldots \ldots \ldots \ldots \ldots \ldots$

10. Summary of tracer spread during retrieval $\ldots \ldots \ldots \ldots \ldots \ldots \ldots \ldots \ldots \ldots \ldots \ldots \ldots$ 


\section{Innovative Grout/Retrieval Demonstration Final Report}

\section{INTRODUCTION AND TECHNOLOGY DESCRIPTION}

This report presents the results of a field demonstration for an innovative buried transuranic retrieval technique. The Innovative Grout/Retrieval Demonstration evaluated an innovative and cost effective approach for full pit and hot spot retrieval in buried transuranic waste sites, involving grouting the waste and followed by retrieval. Grouting the waste provides an agglomeration of contaminants and fine soil particles that decreases the chance of contaminant spread during the inherently dusty retrieval operation. During fiscal year (FY) 1994 the Buried Waste Integrated Demonstration (BWID) performed a full-scale, proof-of-concept field demonstration of this technique in a simulated waste pit.

The innovative approach to hot spot retrieval is to first form a stabilized waste/soil matrix using jet grouting. Jet grouting is accomplished using the CASA GRANDE drill system and a highpressure positive displacement pump. The drill system drives through the soil/waste matrix and injects grout at the bottom of the drill stem as the drill stem is withdrawn from the drill hole. The contaminants are locked in a concrete-like mass by the jet grouting process. Immediately following jet grouting, thin-walled spiral wrapped tubes are inserted into the hole and allowed to set in place. The jet grouted pit is allowed to cure, and following curing, the demolition grout is introduced into the spiral wrapped tubes. As the demolition grout cures, it expands (through the thin-walled spiral wrapped tube) and fractures the soil/waste matrix in situ. Following stabilization with the grout and fracturing by expansion grout, retrieval equipment removes the debris. For the proof-of-concept experiment discussed in this report, a backhoe with a thumb attachment was used for the retrieval action.

The Idaho National Engineering Laboratory (INEL) has $2 \mathrm{M} \mathrm{ft}^{3}$ of transuranic waste buried in shallow land burial (commingled with at least $6 \mathrm{M} \mathrm{ft}^{3}$ of soil). Retrieval and disposal of this waste is one of the options being considered for this waste. The concept of removing selected hot spots and applying a cap to the buried waste is also a consideration. Conventional retrieval using off-theshelf remote excavators for either full pit or hot spot retrieval is expected to create considerable dust. The contamination control systems offered to control the dust spread, and therefore, contaminate spread are untested in radioactive environments. As a result, any technology that enhances the control over dust spread must be pursued.

There have been many studies and experimental retrieval/grout programs that have been performed at INEL including: the Initial Drum Retrieval (IDR) Program ${ }^{1}$ and the Early Waste Retrieval (EWR) Program ${ }^{2}$ during the 1970s, the In situ Grout Program in the late 1980s, ${ }^{3,4}$ and the Cryogenic Retrieval Program in 1992. ${ }^{5}$ During the EWR project, the importance of a strong contamination control system was stressed. This project involved removing soil/waste matrix using personnel wearing bubble suits and small excavation equipment. During one incident a bottle of unknown fluid was spilled in this largely archeological excavation and the project was shut down for weeks dealing with the contaminant spread. Retrieval of buried transuranic waste is expected to occur at a faster rate than during the EWR project, therefore, innovative contamination control strategies must be developed. During the in situ grout experiment, microfine particulate grout was injected using the Richland Hanford Operations process of dynamic compaction and injection of the 
grout using an I-beam supported by a crane. The I-beam had a tube along the length of the beam to inject the grout and the driving force was supplied by a vibrating hammer suspended from the crane. The grout was injected by gravity feed down the length of the tube as the vibrating hammer drove the I-beam into the waste. The results of this study showed that the process caused significant compaction; however, the microfine grout under gravity feed could not penetrate the fine silty-clay soil structure of the INEL soils. It was concluded that other grouting techniques are required. The Cryogenic Retrieval Program conducted during FY-92 was performed to examine the inherent contamination control aspects offered by first freezing the waste and then retrieving it. In the project, liquid nitrogen was introduced into 2-in. diameter schedule 40 freeze pipes that had been driven into the soil waste matrix. The frozen waste matrix was removed using a remotely controlled bridge crane arrangement with a grapple, shear, jackhammer, and special freeze tube break-out tool. The cryogenic retrieval process was successful in removing the soil/waste matrix with minimum dust spread; however, the complexity and costs associated with the liquid nitrogen were high. In fact, the idea to first grout the waste followed by application of the demolition grout were inspired by the cryogenic retrieval project.

For any retrieval option for transuranic waste, contamination control is mandatory to avoid personnel uptake and lengthy delay times for decontamination because retrieval operations could cost "hundreds of thousands of dollars per day" in controlling the spread of contaminants. 


\section{TEST OBJECTIVES}

The objective of this innovative retrieval approach is to demonstrate that retrieval of buried transuranic waste can be simplified and become more efficient by reducing the need for elaborate contamination control schemes such as directed air flow during dumping and continuous sprays. This will be assessed primarily by comparing dust generation and rare earth tracer spread for the innovative grout case and for other retrieval scenarios with various forms of contamination control applied. Another objective of this demonstration is to investigate the proof of principle for the innovative grout/retrieval scheme used by the Environmental Restoration Program in the Comprehensive Environmental Response, Compensation, and Liability Act (CERCLA) process. The data obtained will be used to fully assess the various options available for the retrieval of buried transuranic waste. As part of this demonstration, estimated costs and viability (including time to deploy, grout set-up time, and retrieval time) will be determined. Specific objectives are to (a) evaluate the spread of rare earth tracers as surrogates of plutonium during the injection of grout and during the retrieval phase, (b) determine the efficiency of grouting equipment on a soil/waste matrix as opposed to a soil matrix alone, (c) assess the effectiveness of applying demolition grout to fracture the soil/waste matrix into retrievable pieces, (d) assess the effectiveness of the grouted soil/waste matrix to provide a binder to soil particles so that contamination spread is controlled, and (e) assess the retrieval rates for the grouted soil/waste matrix.

Specific data quality objectives are stated in the test plan for this project. ${ }^{6}$ The demonstration was largely proof of concept in nature, and much of the data are qualitative involving observation of retrieved debris size, time of operation, and volumes of injected grout. However, data taken with high volume air samplers are quantitative and include (a) dust loadings in grams per liter of air measured with a total uncertainty of $\pm 20 \%$ and (b) rare earth tracer content on the filters measured with a detection limit of $1 \mathrm{ppm}$. 


\section{EXPERIMENTAL DESIGN AND PROCEDURES}

The Innovative Grout/Retrieval demonstration was a multiphase project. The first phase involved construction of a simulated full-scale test pit with typical waste containers and materials. Second, a large weather shield was constructed over the cold test pit. Third, field trials for the jet grouting process in the INEL silty-clay soils were performed to optimize the grout formulation and the jet grouting parameters including pressure and withdrawal rate. Forth, the cold test pit was jet grouted and access holes for the demolition grout were established. Fifth, the demolition grout was applied. In the sixth step, the grouted and fractured debris was retrieved. Additional substeps included obtaining a background air sample for dust loading and presence of the rare earth tracer, praseodymium oxide, and a baseline dust and tracer loading for a retrieval actions involving no active contamination control activities. An additional activity was a benchscale study of various soil/Portland cement soilcrete mixtures including compressive strength testing on small soilcrete blocks. The procedures and equipment used in each phase are discussed below.

\subsection{Cold Test Pit Construction}

The proof-of-concept demonstration was performed at the INEL's Cold Test Pit demonstration area located adjacent to the Radioactive Waste Management Complex (RWMC). A single "full-scale" cold test pit was constructed 10 wide $\times 10$ long $\times 10 \mathrm{ft}$ deep containing simulated waste commonly found in the actual transuranic waste pits at the RWMC. These waste containers were 55-gal drums and $4 \times 4 \times 4$-ft boxes containing typical waste materials such as sludge, cloth, wood, metal, plastic, paper, and concrete. The sludge material was a mixture of 40 -gal canola oil, 50 -lbm kitty litter on floor dry, and 33-lbm of Micro Cel-E, a synthetic silicate absorbent. This sludge material represents the absorbed cutting oils or sludges sent to INEL from the Rocky Flats Plant. A total of 25 drums and two boxes containing simulated waste was used for the demonstration. Each container was "spiked" by random distribution with the flour form (about $3 \mu \mathrm{m}$ ) of the rare earth oxide of praseodymium. This tracer has been shown to move like plutonium oxide in an aerosolized dust cloud. ${ }^{7}$ Table 1 summarizes the waste material and mass of the various waste containers. Basically, the containers were made of cardboard to simulate the deterioration process expected in metal drums and plywood boxes interned in shallow land burial for up to 40 years; however, two of the drums were metal drums used to assess the effects of potential shadowing or shielding of the surrounding soil from the jet grouting process. Drums were both randomly oriented and placed in upright or stacked positions as shown in Figure 1. A total of approximately $9,000 \mathrm{lbm}$ of simulated waste was placed in the pit. Figures 2 and 3 are photographs of the cold test pit during the construction phase. Following placement of the simulated waste material in the pit, the pit was backfilled with soil typical of that used in the adjacent Subsurface Disposal Area (SDA) of the RWMC for actual burial.

\subsection{Weather Shield Construction}

A large $(70 \times 80 \times 35$-ft high) weather shield (source: Diamond Party of Salt Lake City, Utah) was constructed over the cold test pit to remove extraneous wind currents when taking air sample data (see Figure 4). The doors of this tent, shown in Figure 4, are open to the north. The average wind direction is from the southwest. The INEL proved to be an extremely inhospitable environment 
Table 1. Cold test pit waste materials.

\begin{tabular}{|c|c|c|}
\hline Container & $\begin{array}{l}\text { Waste description } \\
\text { (container type) }\end{array}$ & $\begin{array}{l}\text { Weight (lbm) } \\
\text { (gross/net) }\end{array}$ \\
\hline $1-4$ & Sludge; drum (cardboard) & $1670 / 1572$ \\
\hline $5-8$ & Sludge; drum (cardboard) & $1652 / 1550$ \\
\hline 9 & Wood; drum (cardboard) & $90 / 85$ \\
\hline 10 & Wood; drum (cardboard) & $78 / 73$ \\
\hline 11 & Plastic; drum (cardboard) & $92 / 87$ \\
\hline 12 & Metal; drum (cardboard) & $296 / 291$ \\
\hline 13 & Concrete; drum (cardboard) & $230 / 225$ \\
\hline 14 & Cloth; drum (cardboard) & $94 / 89$ \\
\hline 15 & Wood; drum (metal) & $142 / 122$ \\
\hline 16 & Metal; drum (cardboard) & $198 / 193$ \\
\hline 17 & Metal; drum (cardboard) & $278 / 273$ \\
\hline 18 & Paper; drum (cardboard) & $32 / 27$ \\
\hline 19 & Paper; drum (cardboard) & $176 / 171$ \\
\hline 20 & Plastic; drum (cardboard) & $50 / 46$ \\
\hline 21 & Metal; drum (cardboard) & $124 / 119$ \\
\hline 22 & $\begin{array}{l}\text { Plastic/wood; drum } \\
\text { (cardboard) }\end{array}$ & $84 / 79$ \\
\hline 23 & Plastic; drum (cardboard) & $202 / 197$ \\
\hline 24 & Concrete; drum (cardboard) & $208 / 203$ \\
\hline 25 & Plastic; drum (metal) & $172 / 152$ \\
\hline 26 & Metal; box (cardboard) & $1348 / 1300$ \\
\hline 27 & Metal; box (cardboard) & $1480 / 1430$ \\
\hline
\end{tabular}

for constructing large fabric structures, and because of high winds (20 to $40 \mathrm{mph}$ ), construction of the tent took about 2 weeks. Normal construction time is 2 days. Future researchers at the cold test pit would be advised to allow a 2-week time period for delays due to wind. A large "micro burst" of wind clocked at $85 \mathrm{mph}$ eventually destroyed 20 weather shields in the later stages of retrieval (July 24, 1994). A smaller $(40 \times 40 \times 12 \mathrm{ft}$ high) "tent" structure (source: Clear Span Tent, Las Vegas, Nevada) was erected over the retrieval site on August 23, 1994, and the retrieval demonstration was completed. 


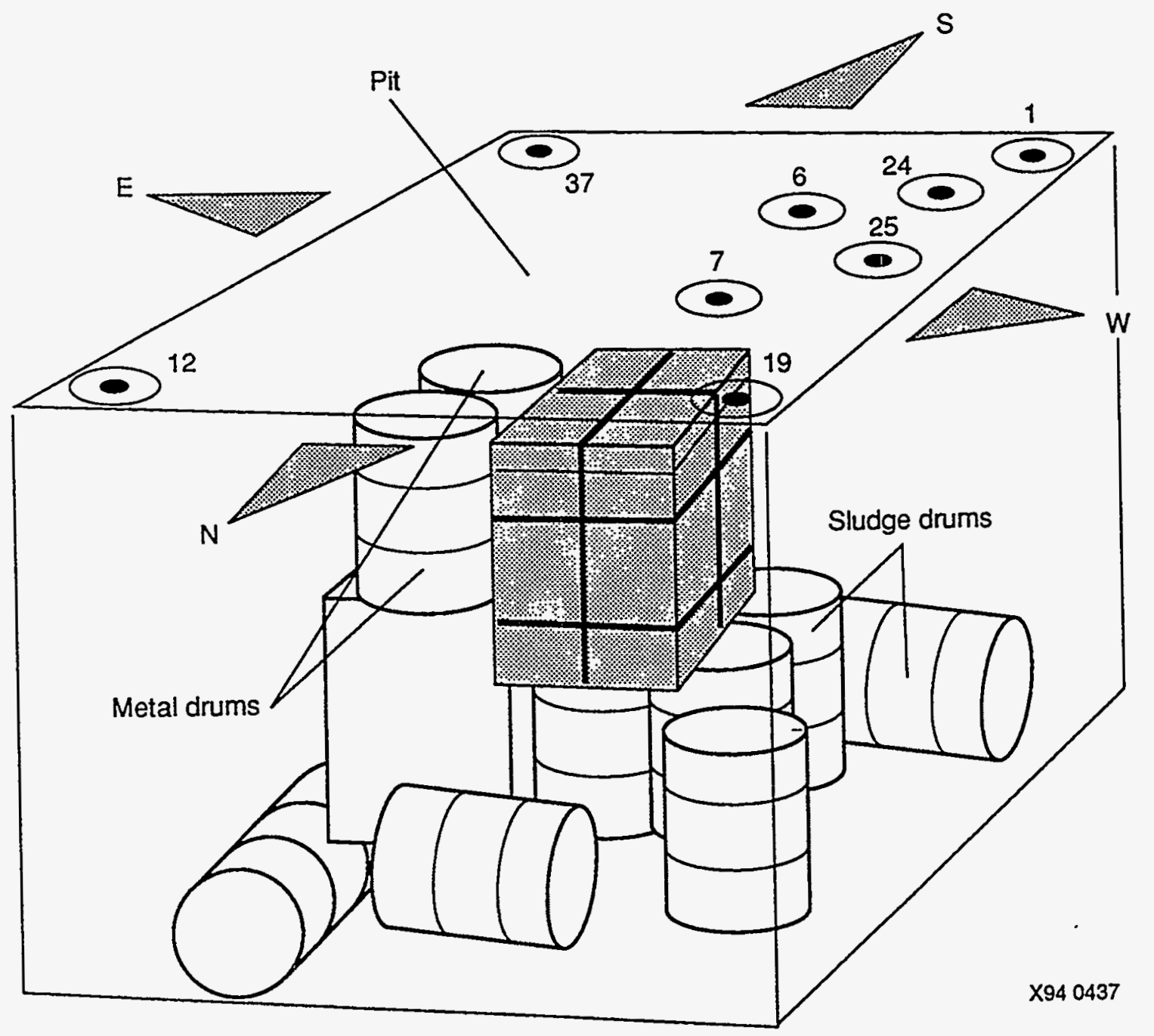

Figure 1. Orientation of waste containers in the pit.

\subsection{Field Trials}

Five jet grouting field trials were performed in compacted INEL soil only in an area adjacent to the simulated pit. These field trials were performed to optimize the grout formulation, injection pressure, and withdrawal rate of the drill stem during the jet grouting process. These field trials involved jet grouting a Portland cement and water mix with the CASA GRANDE high-pressure positive displacement pump (see Figure 5). During these field trials, the CASA GRANDE drill system (see Figure 6) was used to insert the drill stem into previously disturbed but compacted soil to a depth of $12 \mathrm{ft}$. To facilitate the insertion, a slow trickle of water was pumped through the two injector holes in the drill stem; however, drilling into compacted (achieved by driving a 2-yd front end loader) soil only required 30 seconds. For the first two field trial injection holes, a 1:1 mix of Portland cement and water based on volume was used. For the remaining three holes, a 1:1 mix of Portland cement and water based on mass was used. The change to the mass basis of mixing was adopted because the lower viscosity of the grouting "mud" for the volume-based formulation caused 


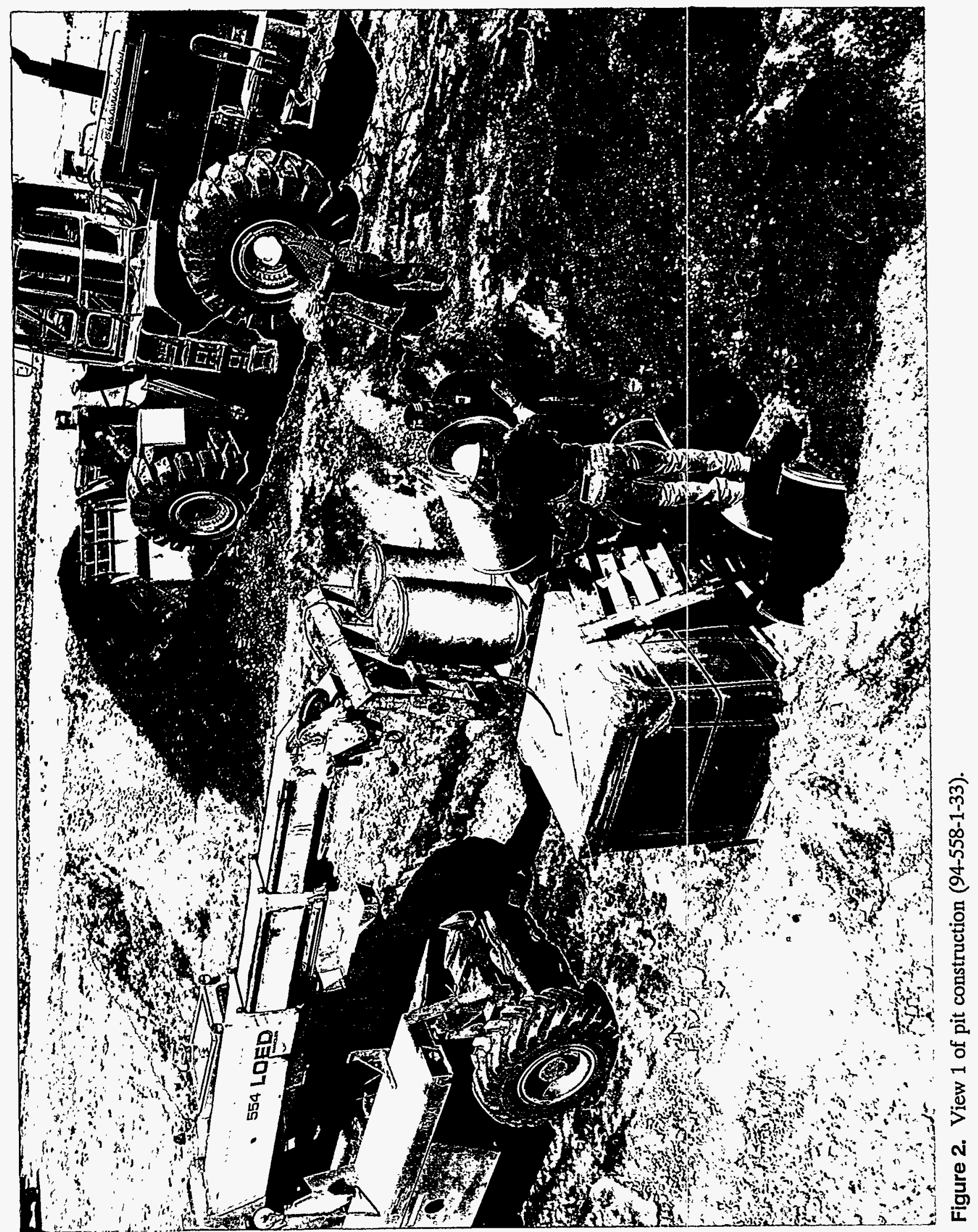




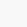




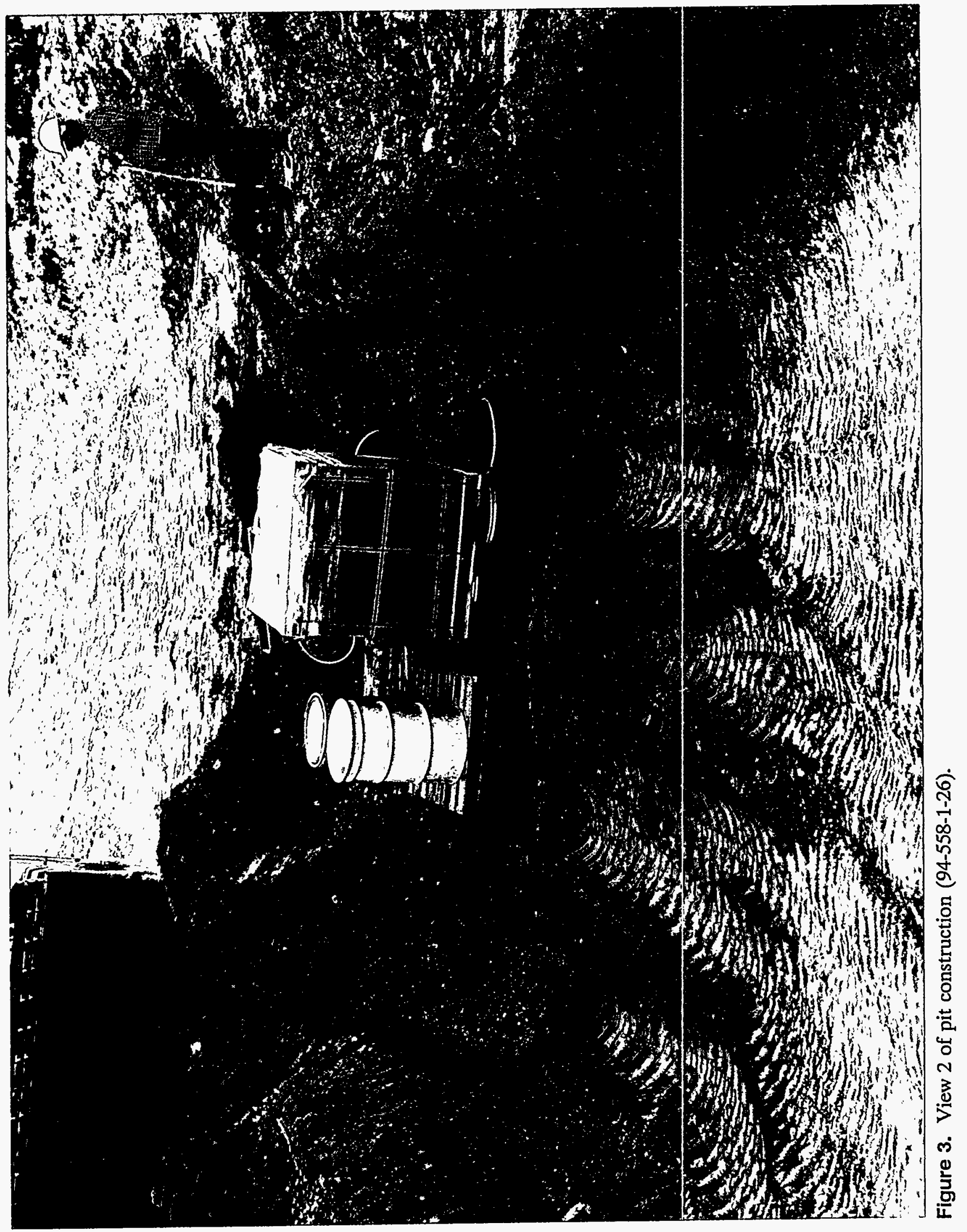





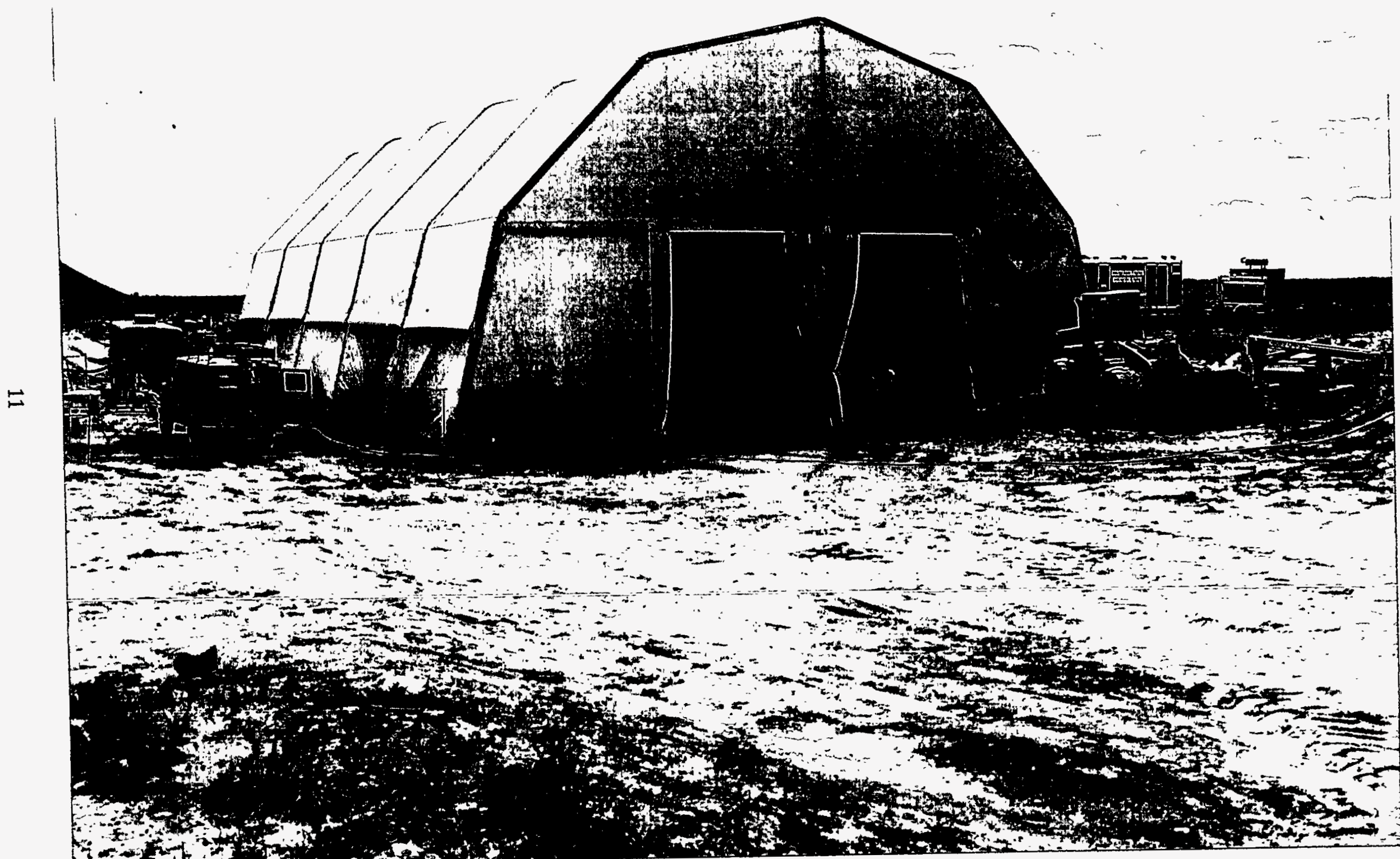

Figure 4. Weather shield for demonstration (94-715-5-3). 


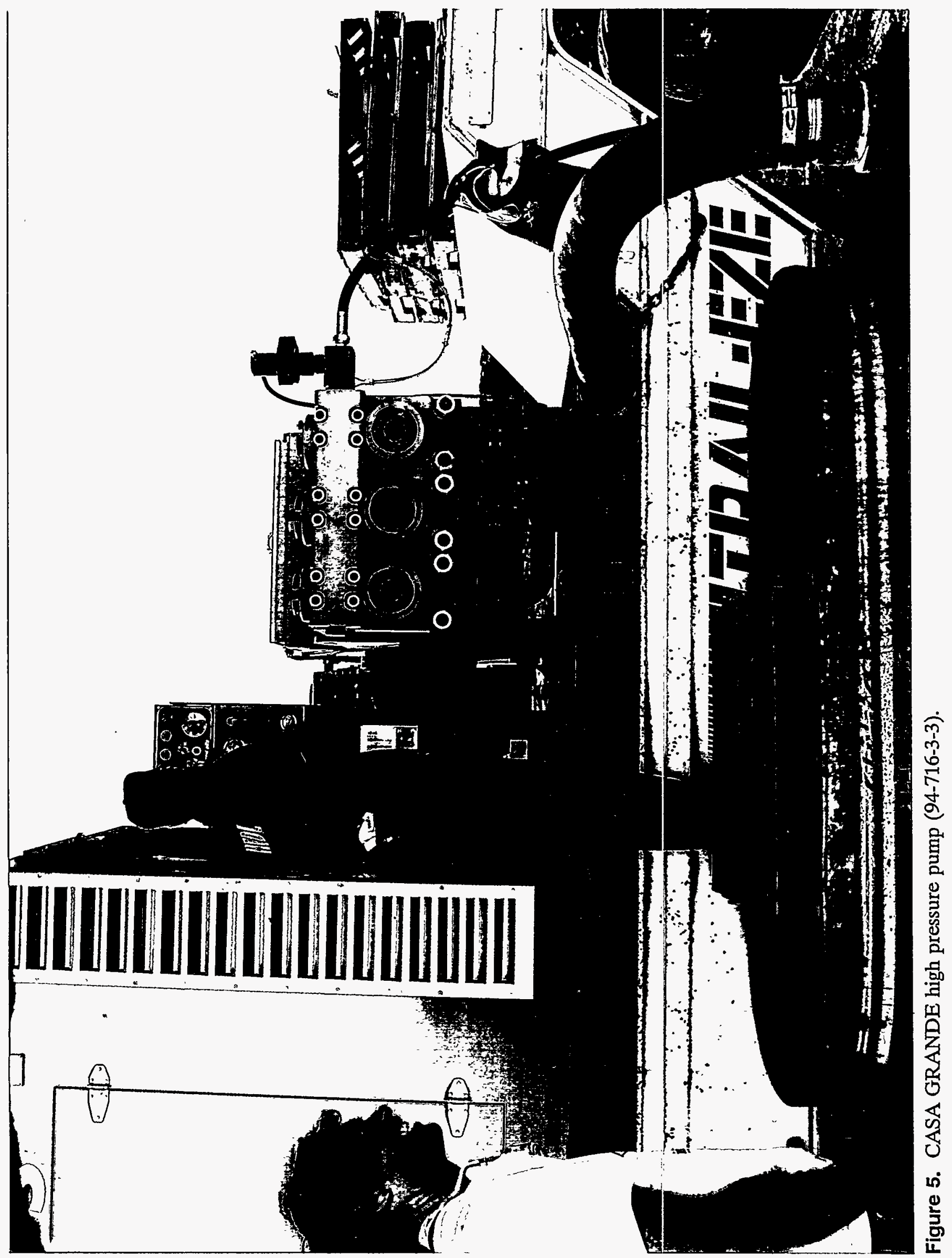





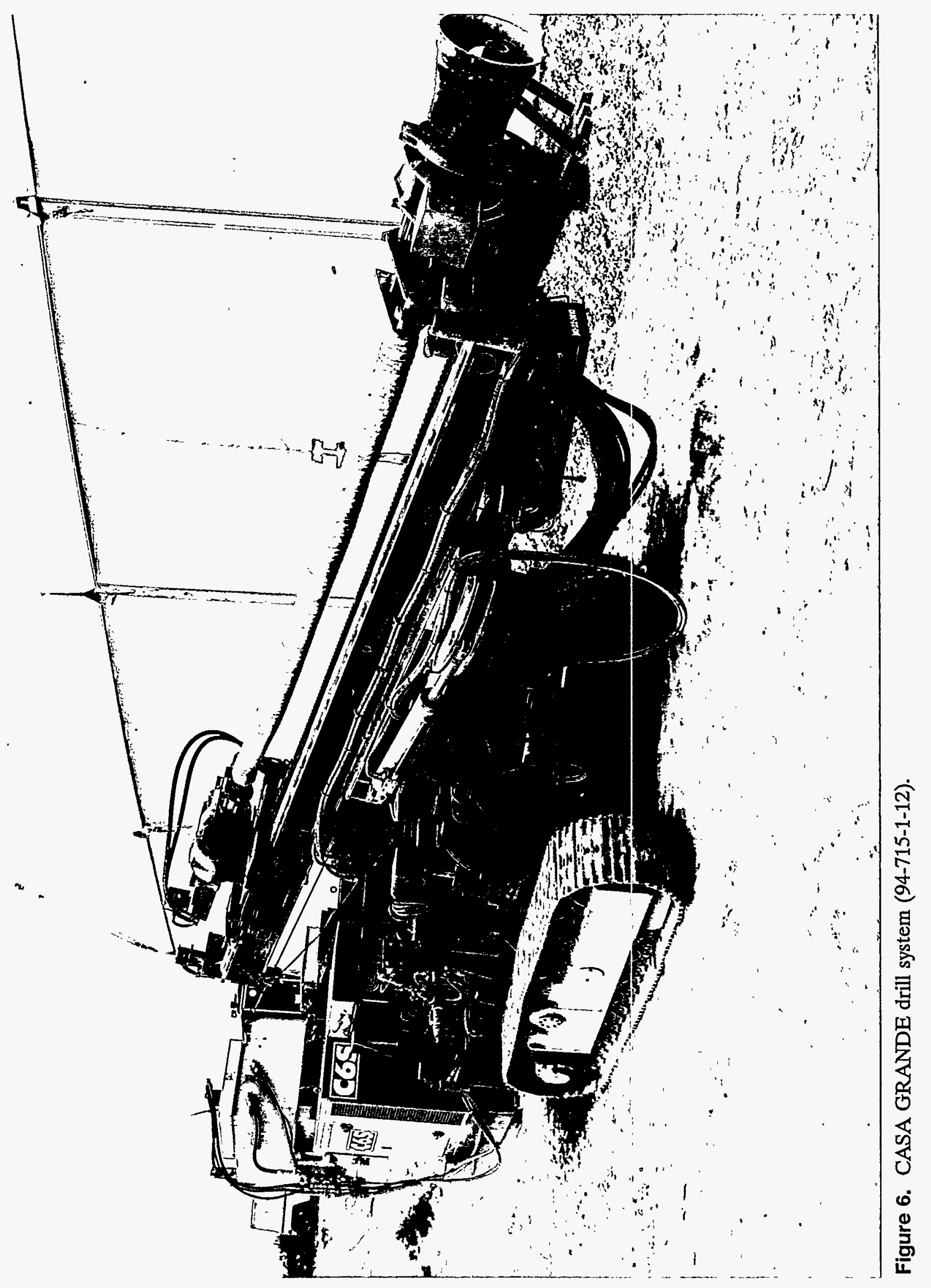



excessive ejection of grouted material out of the ground at the drill stem hole. Field trials 3 through 5 involved variation in the injection pressure and withdrawal rate. The field trial also involved examining the insertion of a 2 in. outside diameter (O.D.) thin-walled spiral wrapped tube into the injection hole immediately after injection. The spiral wrapped tubes were to be used to insert the demolition grout and if they proved successful could save considerable time and potential dust spread because the alternative was to drill access holes through the grouted pit for the demolition grout. Application of the spiral wrapped tubes was done in the field trials for two reasons: (1) to test the application of the BRISTAR demolition grout in an actual soilcrete jet grouted column and (2) to test the ease of hand insertion of the spiral wrapped tube immediately following jet grouting. A spiral wrapped tube was inserted into the third field trial injection hole following the jet grouting process. After allowing the number 3 grout column to cure (the grout was allowed to cure 48 hours), the downhole temperature within the spiral wrapped tube was taken and the BRISTAR 150 product was applied to the hole. Mixing of the BRISTAR is a simple process involving 1 sack of BRISTAR (11 lbm) with 1-1/2 L of $50^{\circ} \mathrm{F}$ water. In the 2-in. tubes, one sack of BRISTAR fills 4.5 vertical $\mathrm{ft}$ of tube. About 2.5 sacks were used in the $12 \mathrm{ft}$ of tube in the field trial. The final phase of the field trials was a destructive examination of the five grout columns. This was accomplished using a 2-yd front end loader and a standard backhoe. A photographic record of this process was kept and observations were recorded in the logbook.

\subsection{Grout Injection}

The entire simulated waste pit was jet grouted using the techniques developed during the field trials. An alternating triangular pattern approach was used so that there was more potential to puncture each container in the pit especially the vertically oriented drums as shown in Figure 7. The numerical order shown on Figure 7 corresponds to the order in which the holes were grouted. Skipping to various positions in the pit was done to avoid causing the grout injected in one hole to push soilcrete mixtures up adjacent holes. The setting time of the grout was thought to preclude this extrusion of grout in adjacent holes. The drill was placed at the 12-ft level from the ground surface and the jet grouting process was begun. The grouting was stopped at about the 4-ft level or if copious amounts of grout emanated out the top of the pit.

A typical grouting cycle involved the following steps. A spoils collection pit ( $1 \mathrm{ft}$ diameter, $1 \mathrm{ft}$ deep) was dug in the position of the proposed grout hole. The CASA GRANDE drill system was positioned over the desired grout hole and the drill stem was inserted into the pit $12 \mathrm{ft}$ or to the point of refusal. Figure 8 shows a typical starting position for the jet grouting operation with the spoils pit in place and the drill stem fully inserted into the pit. Once the drill was extended into the hole to a depth of $12 \mathrm{ft}$ or the point of refusal, the jet grouting operation was started. This involved simultaneously pumping grout at nominally 6,000 psi while withdrawing the rotating drill stem at a pre-programmed rate. For this demonstration, the drill stem was withdrawn in 5-cm increments at a rate of 6 seconds and with a rotation of 2 revolutions/second step on the drill stem. Once the drill stem was withdrawn, a 2-in. diameter thin-walled spiral wrapped tube was inserted by hand into the hole. The drill stem was 4-9/16 in. O.D. so the 2-in. tube was easily hand inserted into the pit. After insertion, the tube was trimmed with a hack saw to about 9 in. above the surface of the pit and a metal fence post was inserted with the driving point end upward to counter the buoyancy forces caused by the grout. The thin-walled tube was sealed on the bottom by crimping the bottom and applying duct tape. 


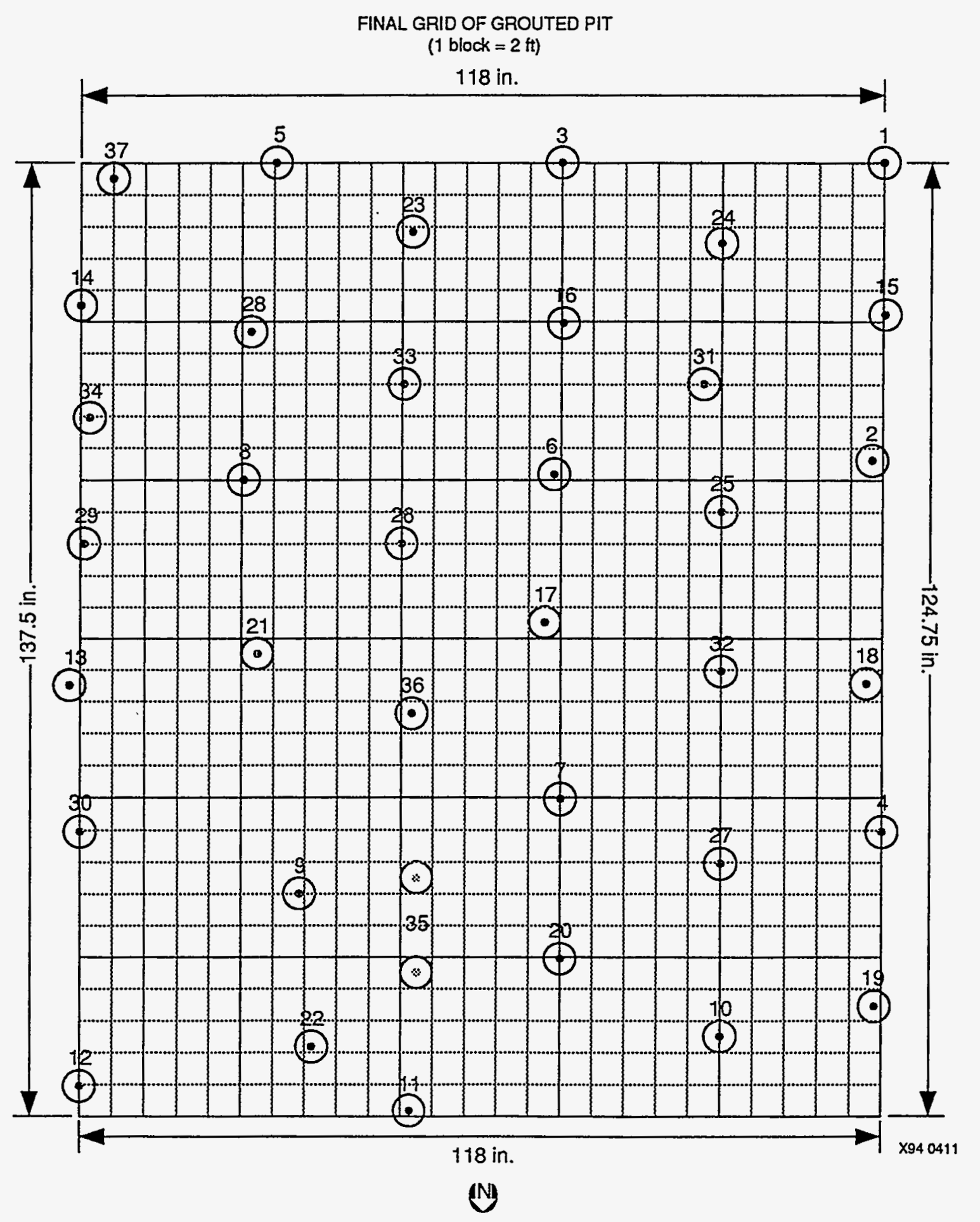

Figure 7. Final grid of grouted pit. 


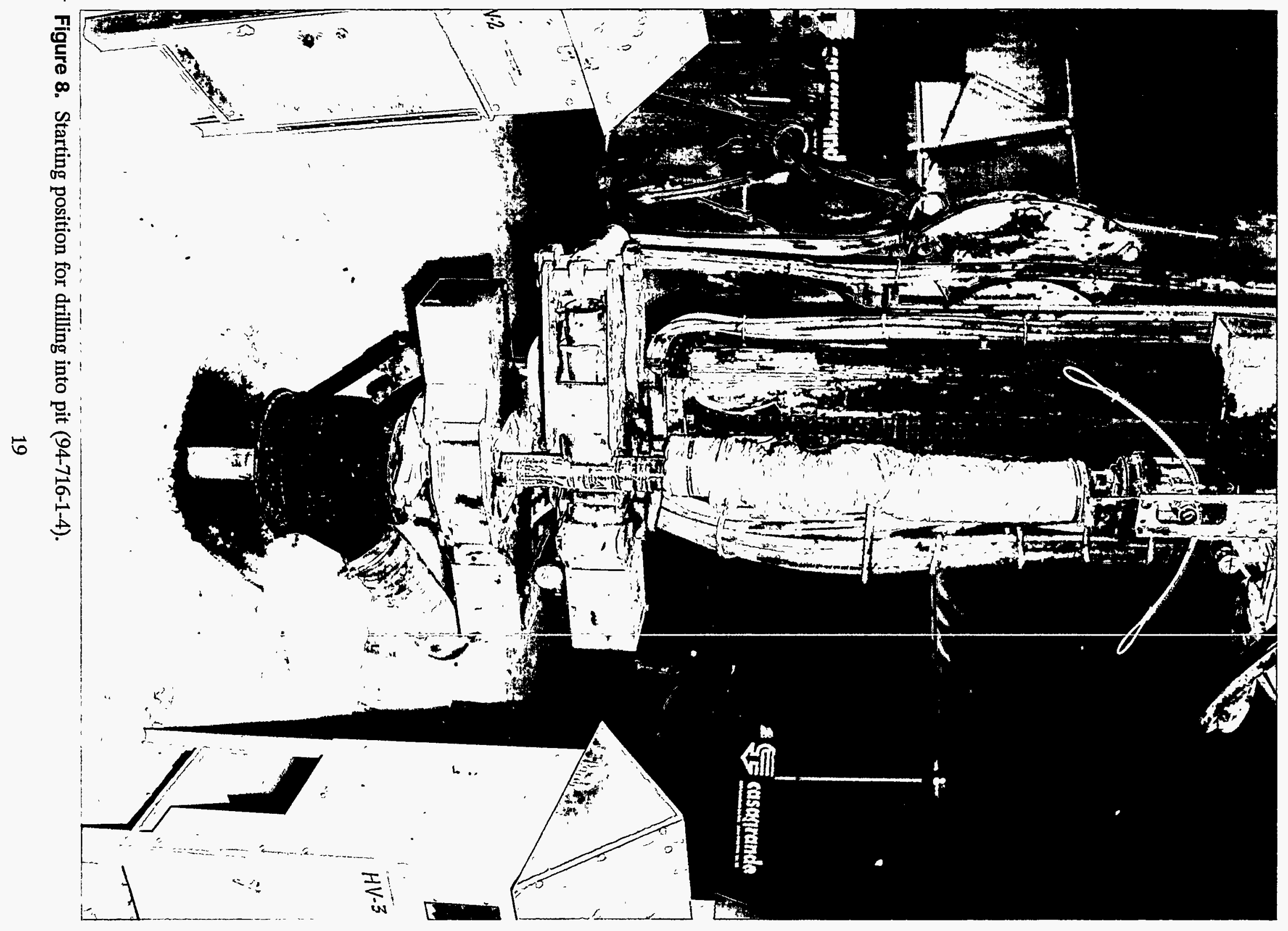



Figure 9 shows the pit after application of the jet grouting with the tops of the spiral wrapped tubes showing above the surface of the pit.

\subsection{Demolition Grout Application}

Following completion of the grouting operation, the demolition grout was applied. Prior to application of the grout, the pit was allowed to cure. During the curing process the water originally in the grout "hydrates" with an exothermic reaction. This causes a large temperature increase in the pit. Since the demolition grout of choice (BRISTAR) offered a variety of grouts depending on the temperature of application, the temperature at the bottom of the spiral wrapped tubes were measured and recorded using a mercury bulb thermometer over a 1-week period in each hole to determine which version of the demolition grout to use. Appendix A contains a detailed description of the BRISTAR product showing the suggested temperature ranges.

There were three separate applications of the BRISTAR grout during the demolition grout phase. The first application was performed under the direction of a representative of the BRISTAR company, and after applying grout BRISTAR 100 in about half of the holes, a blowout occurred caused by a steam explosion. The area was evacuated and about 10 more blowouts occurred. Blowout is an expected phenomenon if the temperature in the hole is higher than that recommended by the product. Blowouts are a steam explosion caused by the heat of hydration produced as the demolition grout cures. After waiting overnight, a second application of a higher temperature version of BRISTAR was applied (BRISTAR 100S) without incident. Following retrieval of approximately one-half of the pit, a third application of Special BRISTAR was applied to four specially drilled holes in the resulting monolithic block. In Section 4, Test Results, details on the efficiency of the demolition grout, an evaluation of the temperature of the pit, and a discussion of the blowout are given. Application of the BRISTAR involves determining the temperature of the application and choosing the correct product, mixing the product with an electrical drill mixer using clean, cool (less than $50^{\circ} \mathrm{F}$ ) water and pouring the grout down the spiral wrapped tube. This process is shown during the actual operation in Figures 10 and 11. An additional step was to insert a 4 mil polyethylene tubes into the spiral wrapped tube to ensure that the BRISTAR grout could not access potential voids in the pit and flow out of the tube. However, in some tubes, the plastic liner was not applied and the grout remained in the tube. Crimping the bottom of the tube and applying duct tape was sufficient to seal the tubes.

\subsection{Retrieval}

Following application of the BRISTAR, the demolition grout was allowed to cure for 2 days. Following this curing period, an access pit was dug adjacent to the grouted pit. In the process of digging the access pit, a background aerosolized dust loading for a retrieval operation was accomplished in clean (no tracer) soil using a standard backhoe. Figure 12 is a view looking south from the entrance of the access pit toward the grouted pit, and Figure 13 is a view looking north across the grouted pit to the access pit and the entrance of the tent. Prior to the retrieval operations, the entire area was sprayed with a dust suppressant called FLAMBINDER (calcium lignosulfanate). This product has been used in other contamination control strategies ${ }^{8}$ involving sprays, dust suppressants, and fixants. The retrieval was accomplished using a backhoe with a special thumb attachment to grasp large consolidated pieces of the debris shown in Figures 14 and 15. Retrieval 
of the pit was accomplished in three sessions. Each session removed approximately one-third of the grouted pit, and the total time for retrieval of the $10 \times 10 \times 10$-ft grouted pit was 288 minutes or 4 hours and 48 minutes of actual digging time. The technique used for digging was to "peel off" large chunks of the grouted pit from the top as shown in Figure 16. For the first two sessions, the top overburden of soil ( 3 to $4 \mathrm{ft}$ thick) was removed as part of this peeling action. For the third session, the top overburden was removed separately and the peeling action was done on the grouted pit only.

\subsection{Air Monitoring}

The main quantitative data for this demonstration were monitoring air for dust and tracer (praseodymium oxide) movement using high volume (HI-VOL) air monitors. These HI-VOL air monitors allow a nominal 10 to $20 \mathrm{cfm}$ of air to pass through 4-in. filters as shown in Figure 17. The filters are weighted before and after a particular run for general dust loading and also analyzed using Inductively Coupled Plasma Mass Spectroscopy (ICP-M5) for praseodymium content in parts per million. Background air samples were taken for a no-action case and the data were adjusted to this background. For all major phases of the demonstration, a total of eight samplers were strategically placed around the perimeter of action for either grouting or retrieval. Figure 18 is an example of the HI-VOL placement during the grouting phase of the demonstration. Details of the results of the air monitoring activities are given in Section 4 of this report.

\subsection{Predemonstration Grout Experiments}

Prior to performing the field demonstration, a grout formulation experiment was performed at Westinghouse Hanford Company laboratories. These tests examined several grout formulations for compatibility with the CASA GRANDE jet grouting operation and performed compressive strength testing on several soil/grout mixtures. Appendix B provides the results of this testing. 


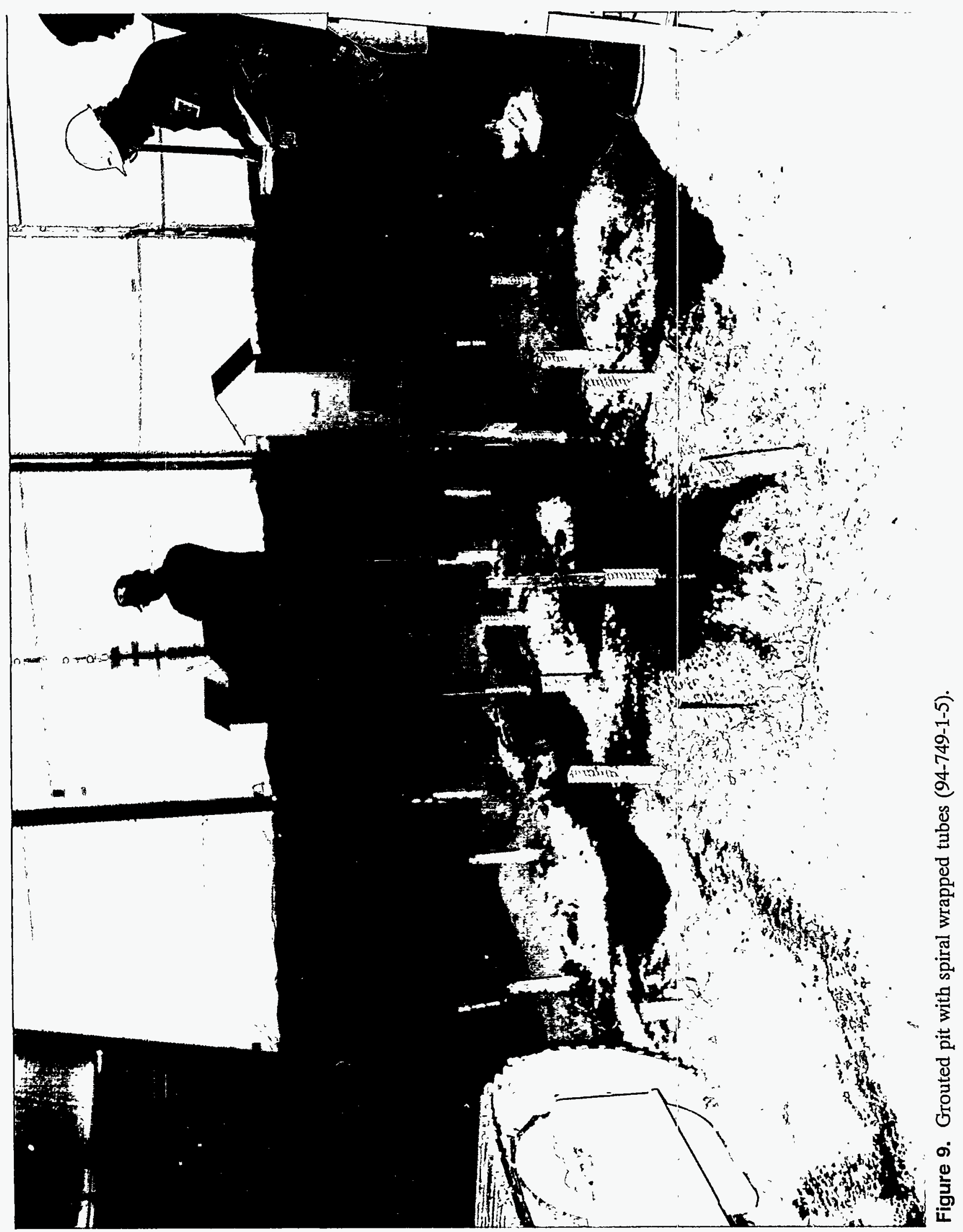





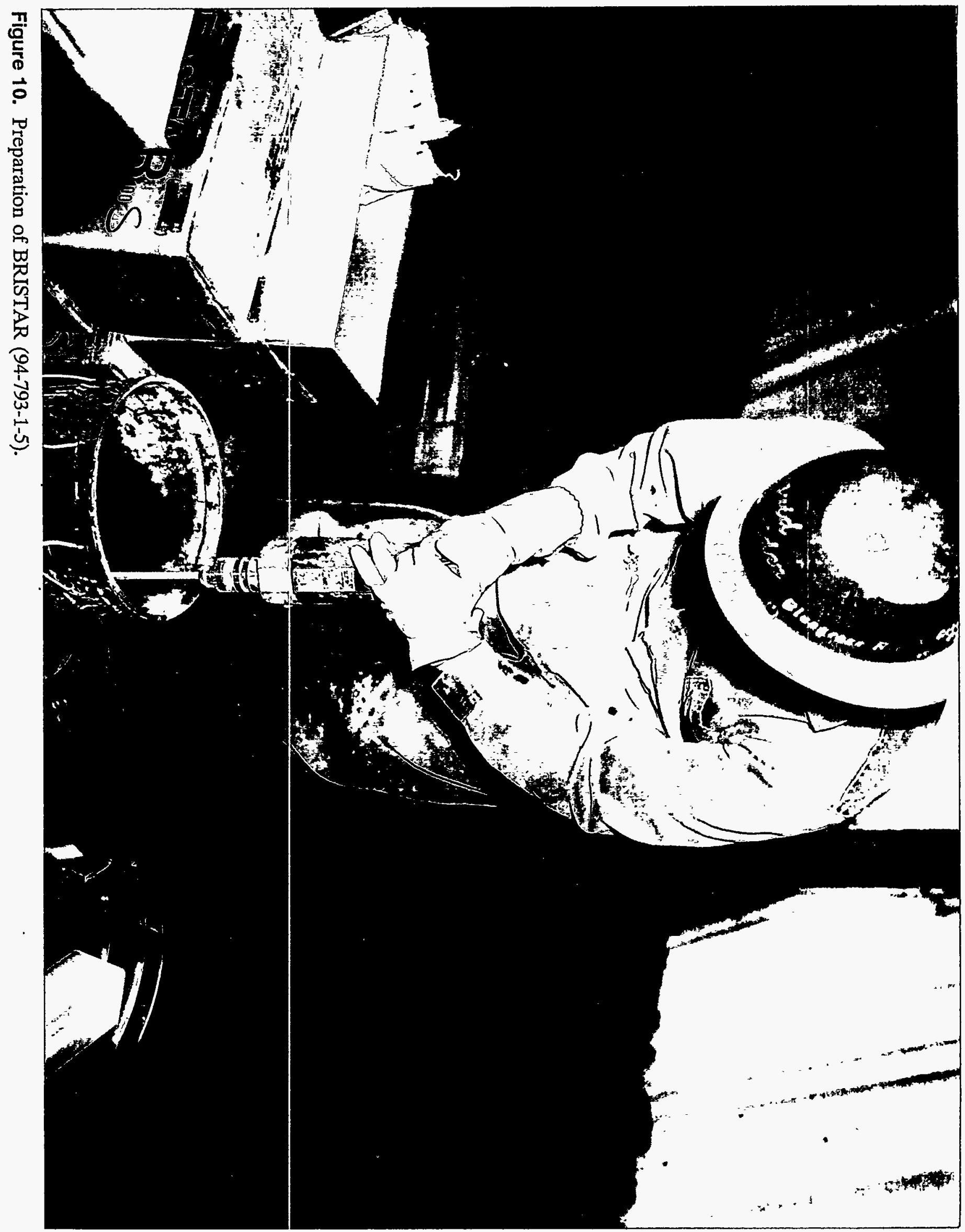





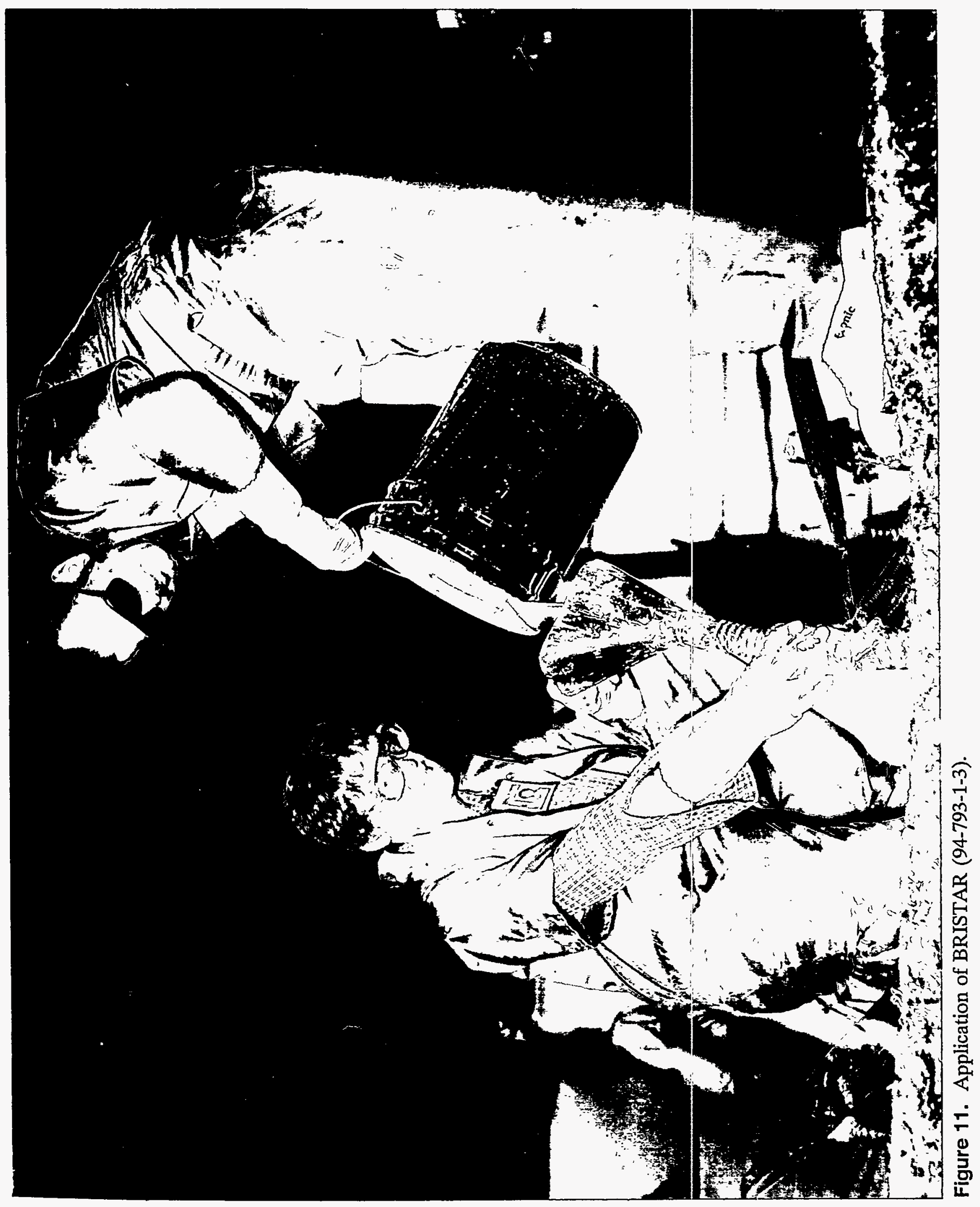




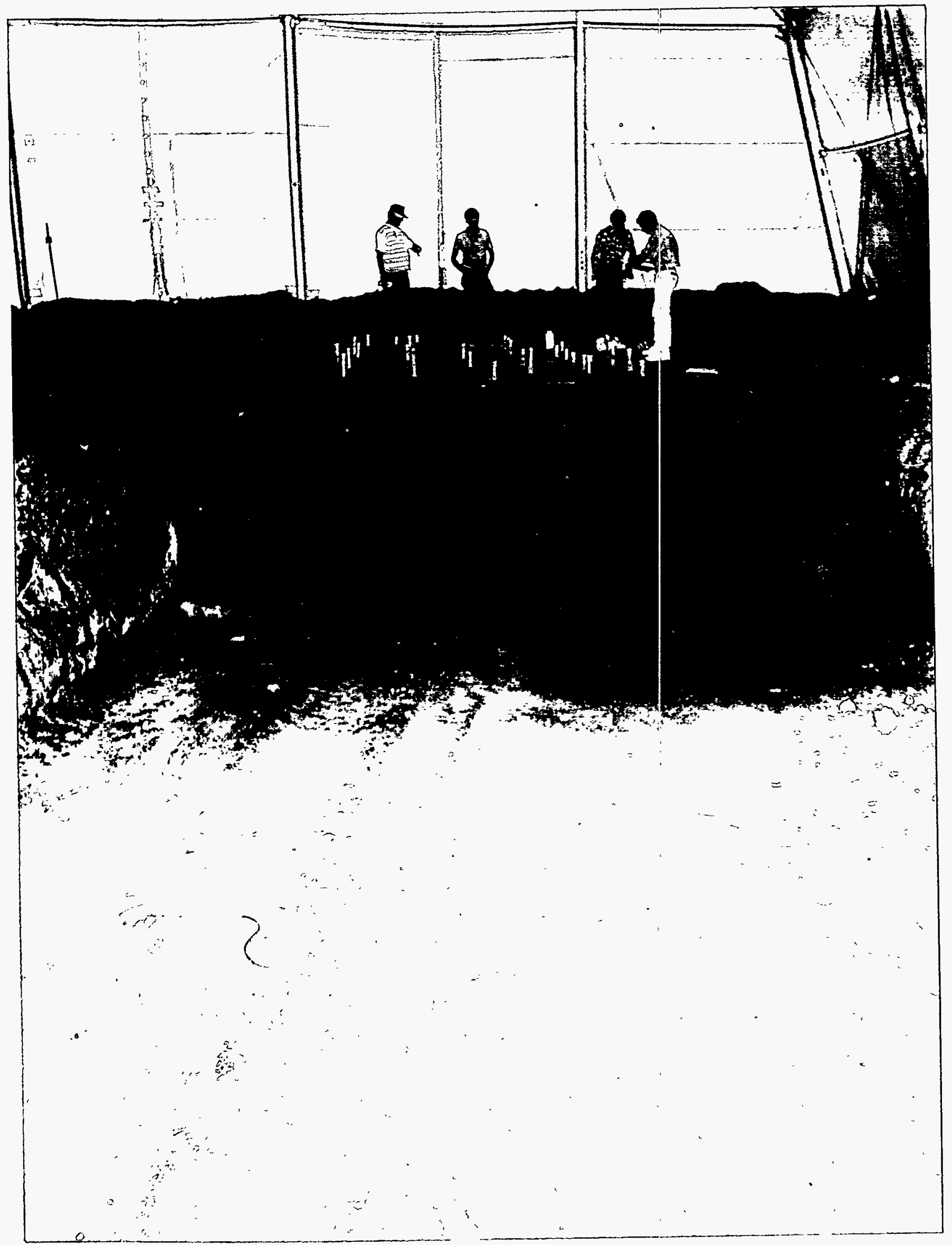

Figure 12. Access pit looking south (94-919-1-3). 



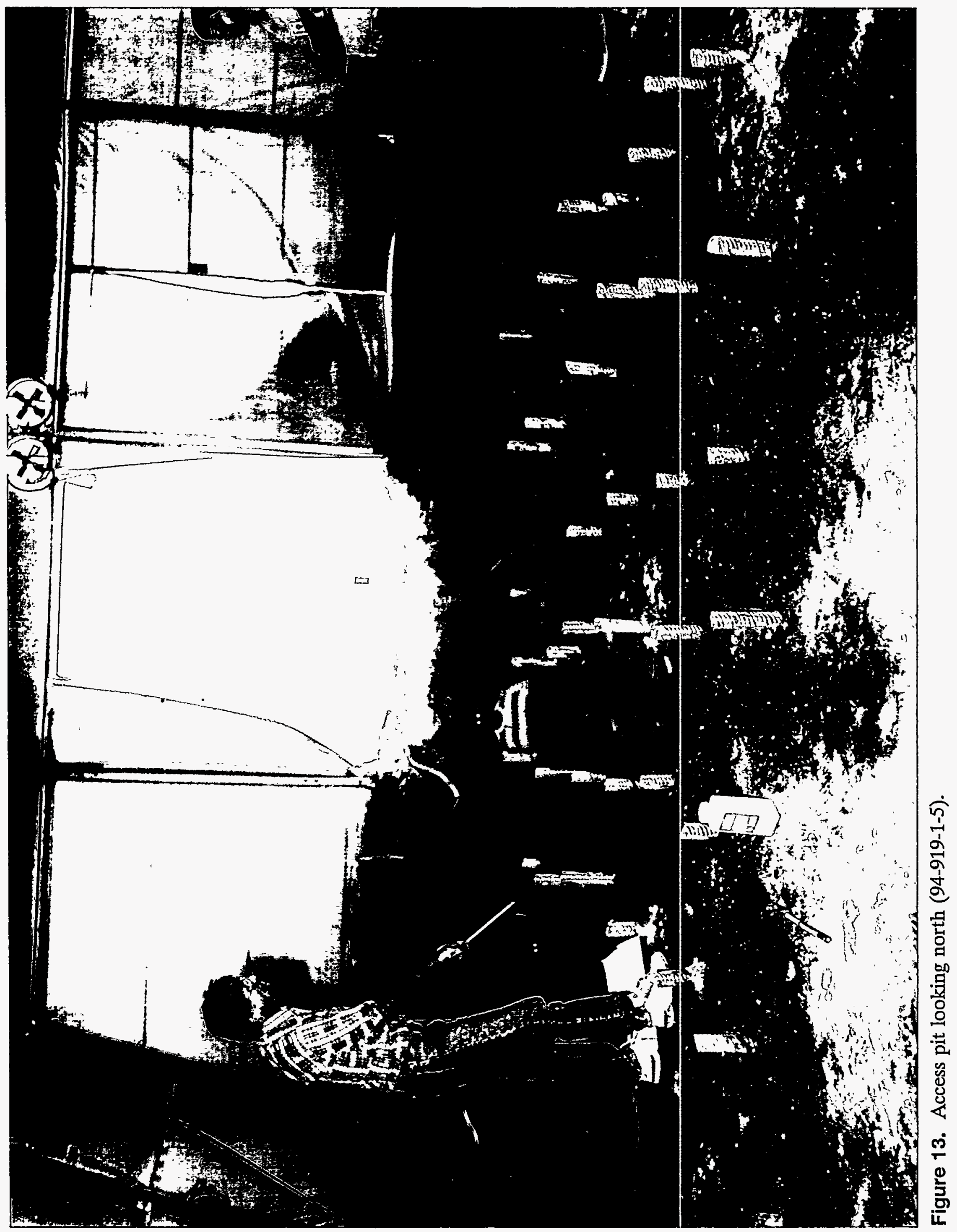


- 


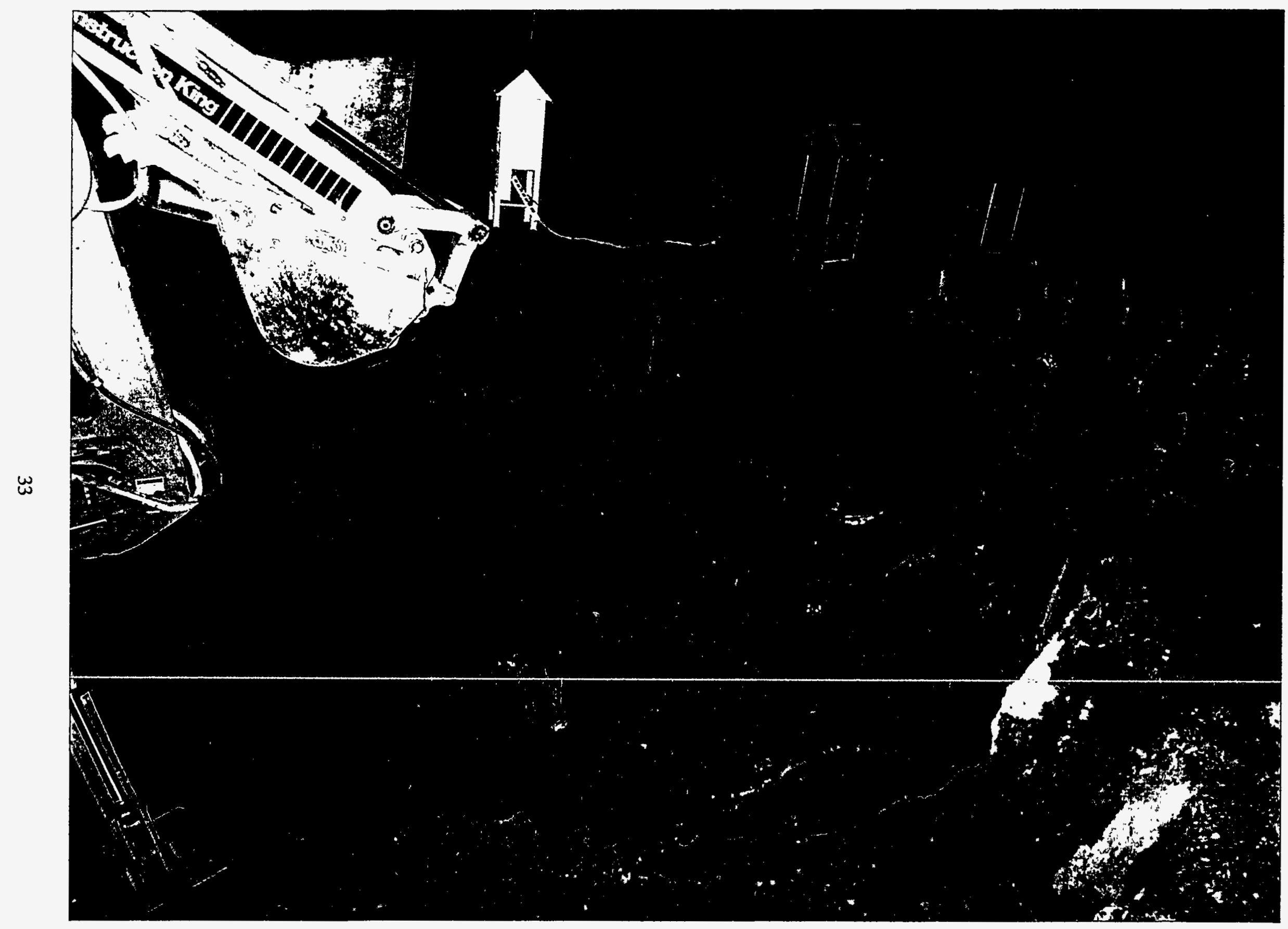

Figure 14. Backhoe in digging position in access pit (94-837-1-13). 



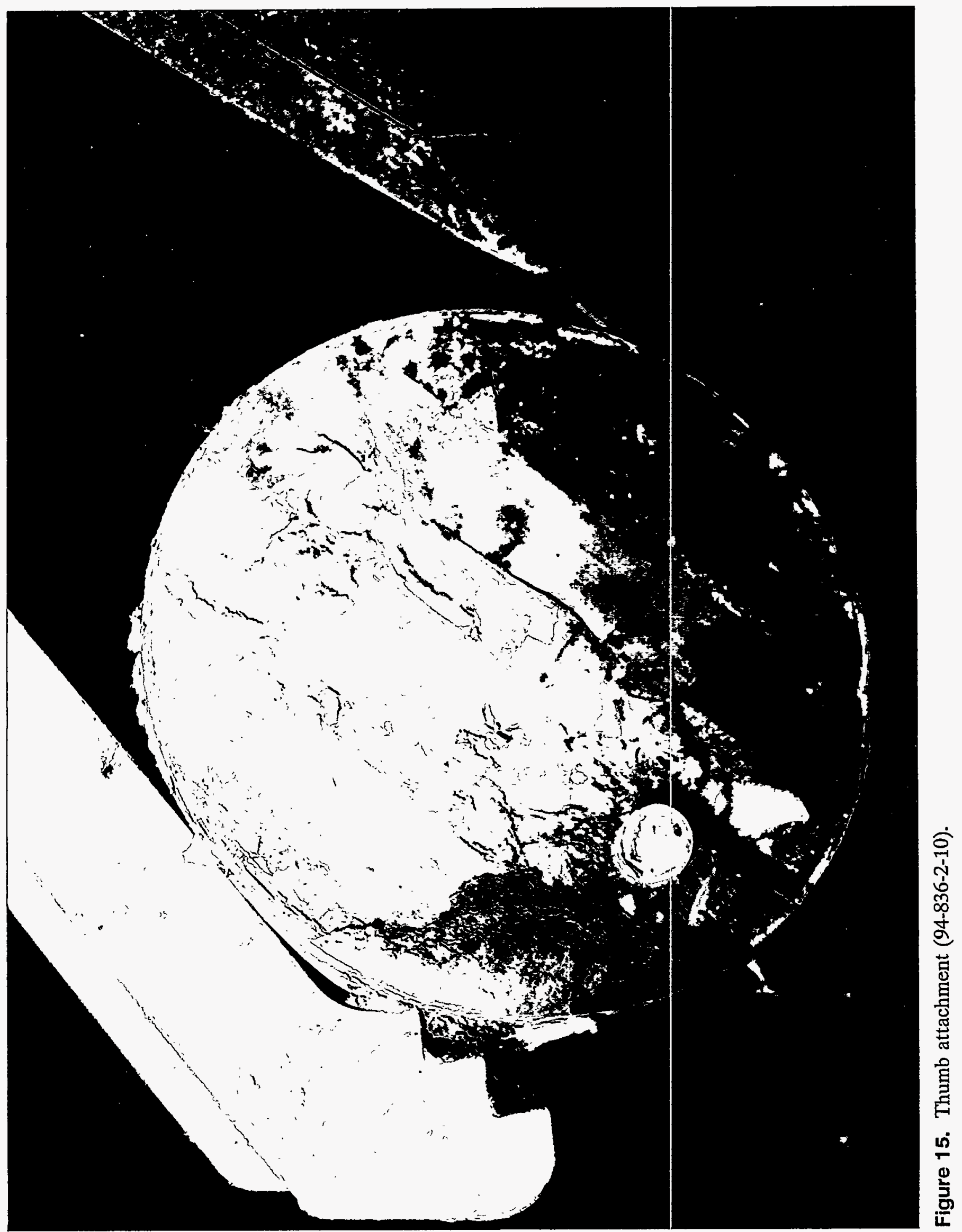





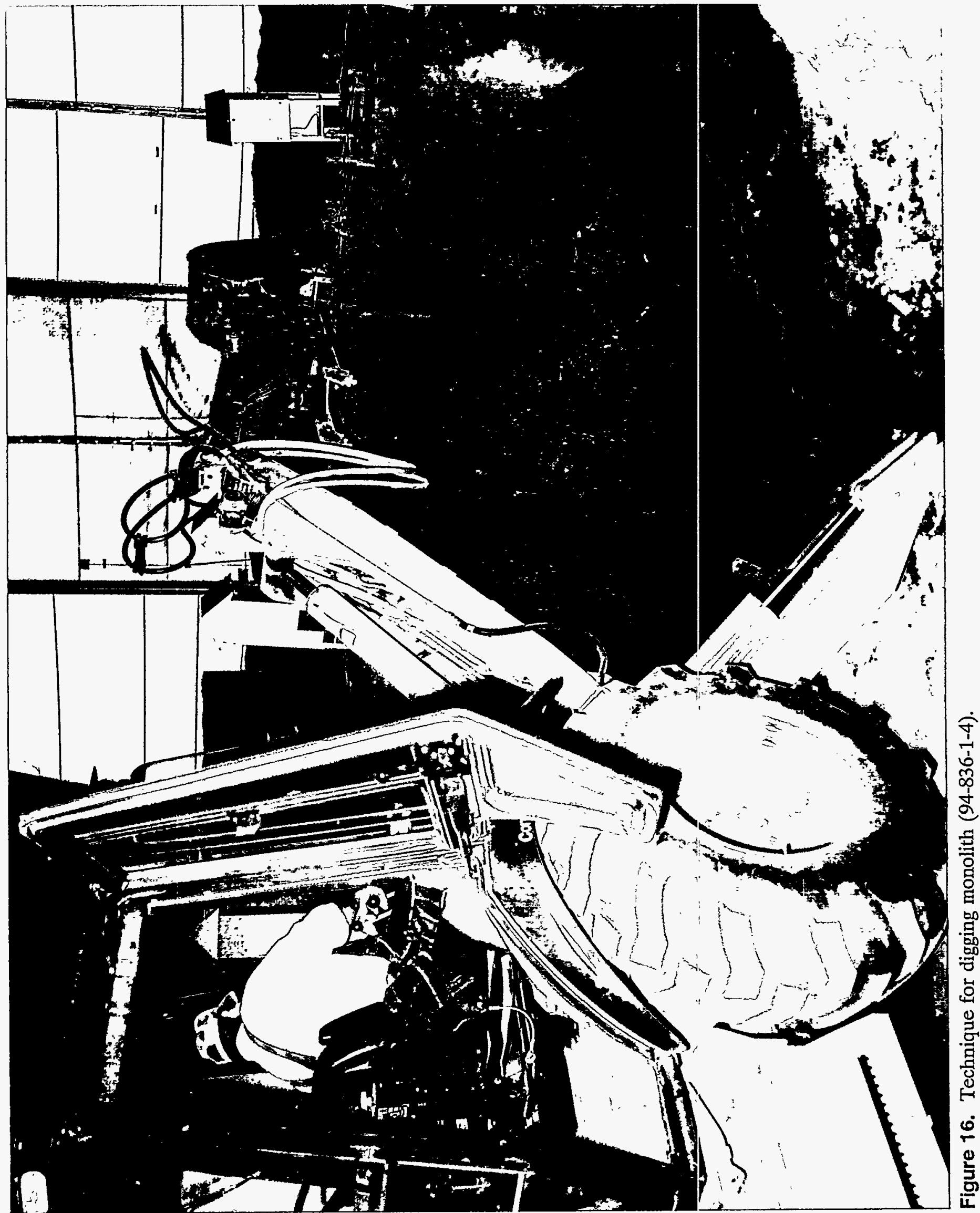





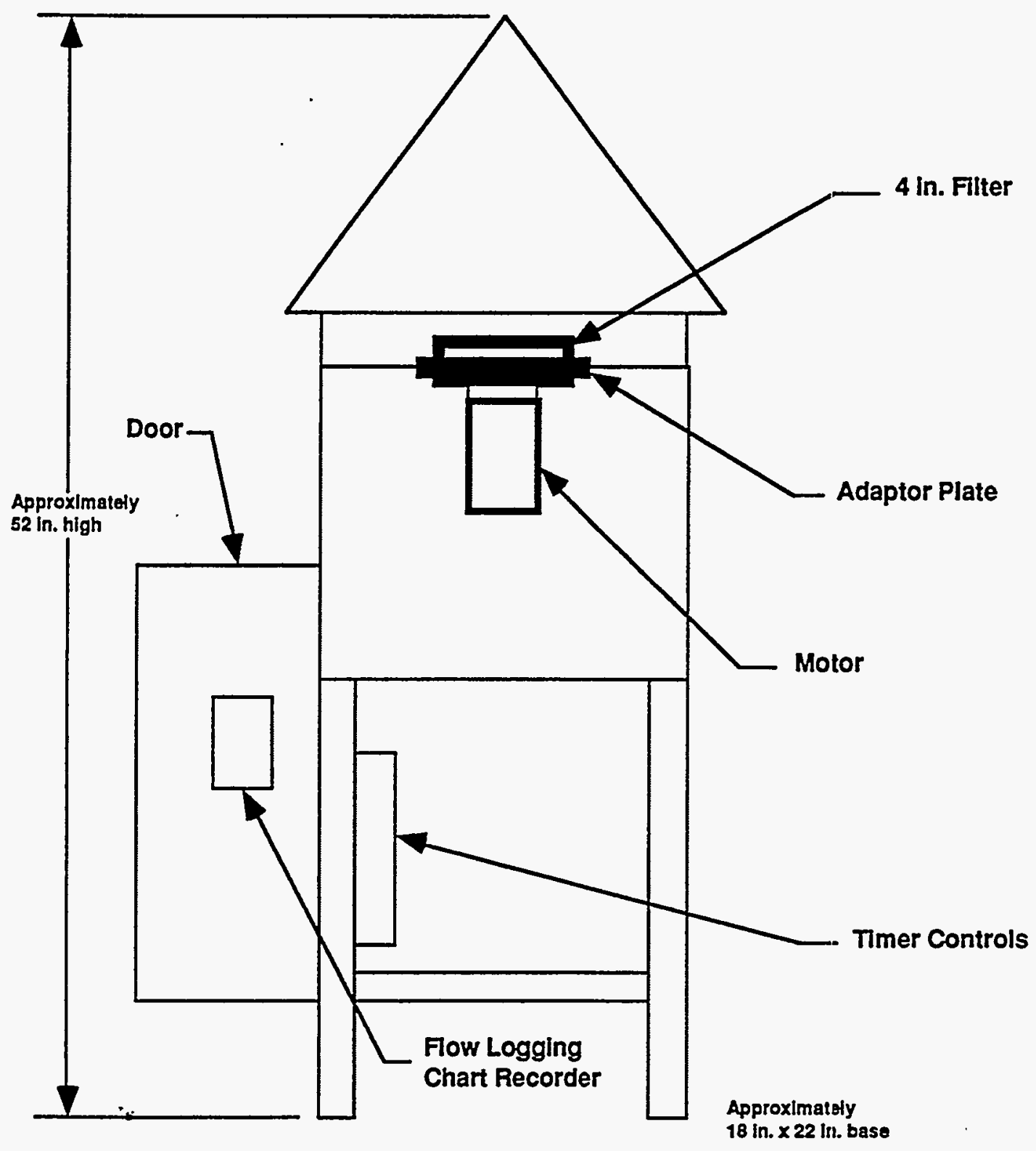

Figure 17. High-volume air sampler. 


\section{-}




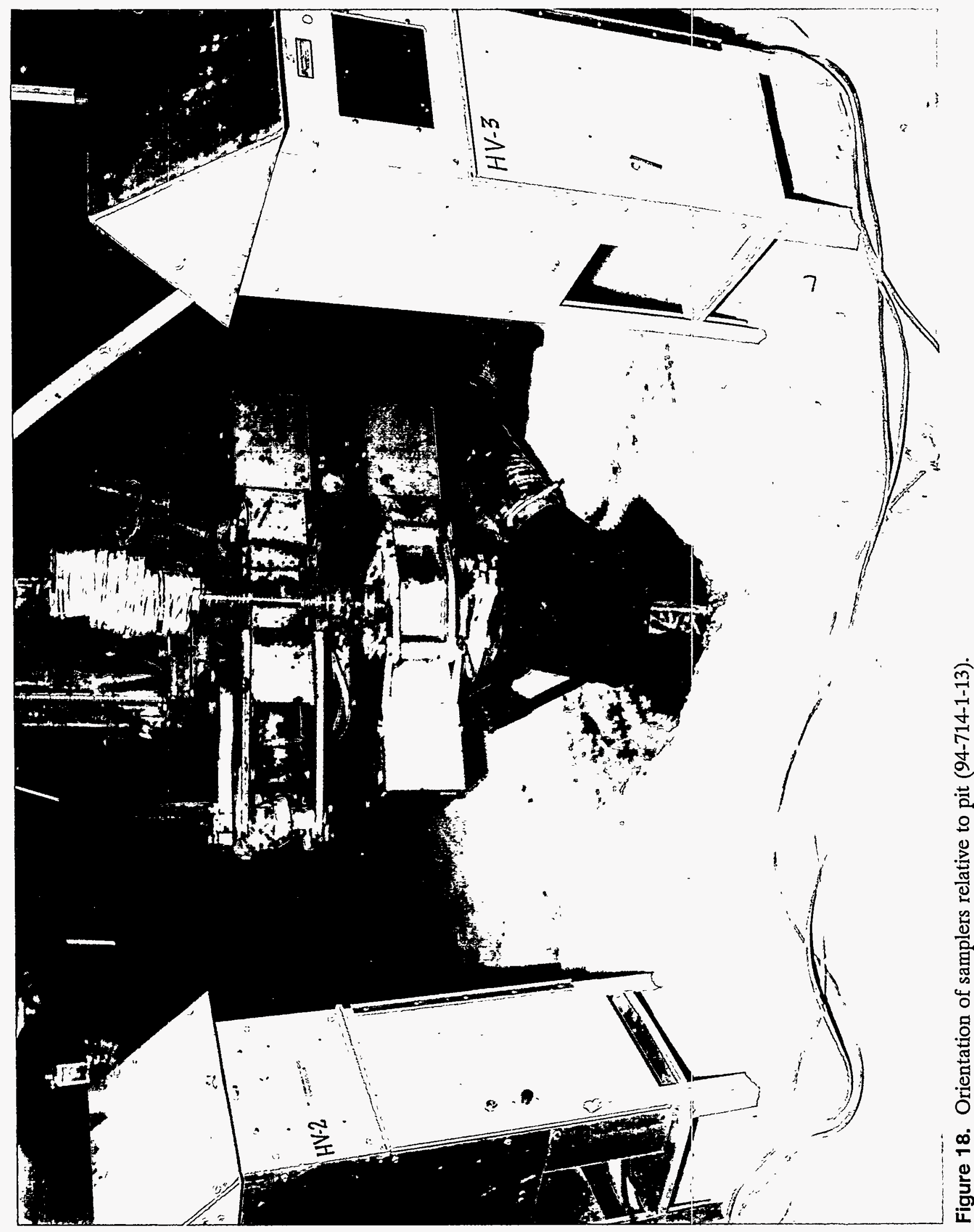





\section{TEST RESULTS}

This section presents the testing results and is organized according to the sequence of operations with discussions on field trials, grouting, demolition grout application, retrieval, and dust control/contamination control.

\subsection{Field Trials}

The field trials provided confidence that the jet grouting process could be applied to the INEL soil types and would be applicable to the simulated waste pit. The field trials allowed setting critical jet grouting parameters and setting the correct hole spacing for the actual grouting of the simulated pit. Table 2 summarizes the key parameters investigated during the field trials including pump pressure, rotational speed of the drill bit, extraction time, and withdrawal distance. Five soil/grout columns were created in an area adjacent to the simulated waste pit. These test columns were created to set the parameters for the grouting operation including the Portland cement/water mix and withdrawal rate of the drill stem and to determine the optimum spacing for the grout holes in the simulated pit. In addition, by grouting in the soil only first was thought to represent a more difficult case for penetration of grout compared to grouting in a buried waste site with containers of waste. This is because tightly packed soil with a fine silty-clay soil pattern is more difficult to penetrate than loose material. The grout columns were created in previously disturbed soil that had been compacted with large (2-yd front end loaders) earth moving equipment. The first two grout columns used a mix of 1:1 Portland cement and water on a volume basis. This equates to a 1.3:1 Portland cement and water ratio on a mass basis. Using a $5-\mathrm{cm}$ withdrawal distance and a rate of 10 seconds per $5 \mathrm{~cm}$, copious amounts of grout (up to $1 / 2 \mathrm{yd}^{3}$ ) extruded out of the drill hole during grouting. Based on the extrusion of grout out the first hole, the remaining three holes used a mixture of 1:1 Portland cement to water based on mass and a withdrawal rate of 6 seconds per $5 \mathrm{~cm}$. The intent of the field trials was to "tie" the grout columns together by placing the columns close to each other. Figure 19 shows the relative spacing of the grout holes for the field trials. The holes were jet grouted in order to preclude uncured grout from extruding up adjacent hole. Skipping a space allowed time for the grout to cure in the adjacent hole, eliminating the extrusion effect. For holes 3 through 5, a great reduction occurred in the amount of grout that extruded to the top of the holes.

Table 2. Field trail jet grouting data.

\begin{tabular}{ccccc}
\hline Hole & $\begin{array}{c}\text { Pump pressure } \\
(\mathrm{psi})\end{array}$ & $\begin{array}{c}\text { Rotational } \\
\text { speed } \\
(\mathrm{rpm})\end{array}$ & $\begin{array}{c}\text { Extraction } \\
\text { time } \\
(\mathrm{s})\end{array}$ & $\begin{array}{c}\text { Withdrawal } \\
\text { distance } \\
(\mathrm{cm})\end{array}$ \\
\hline 1 & 5800 & 1500 & 10 & 5 \\
2 & $2900-4350$ & 1500 & 6 & 5 \\
3 & $5800-6225$ & 1500 & 6 & 5 \\
4 & $2900-4350$ & 1500 & 6 & 5 \\
5 & $6225-7250$ & 1500 & 6 & 5 \\
\hline
\end{tabular}




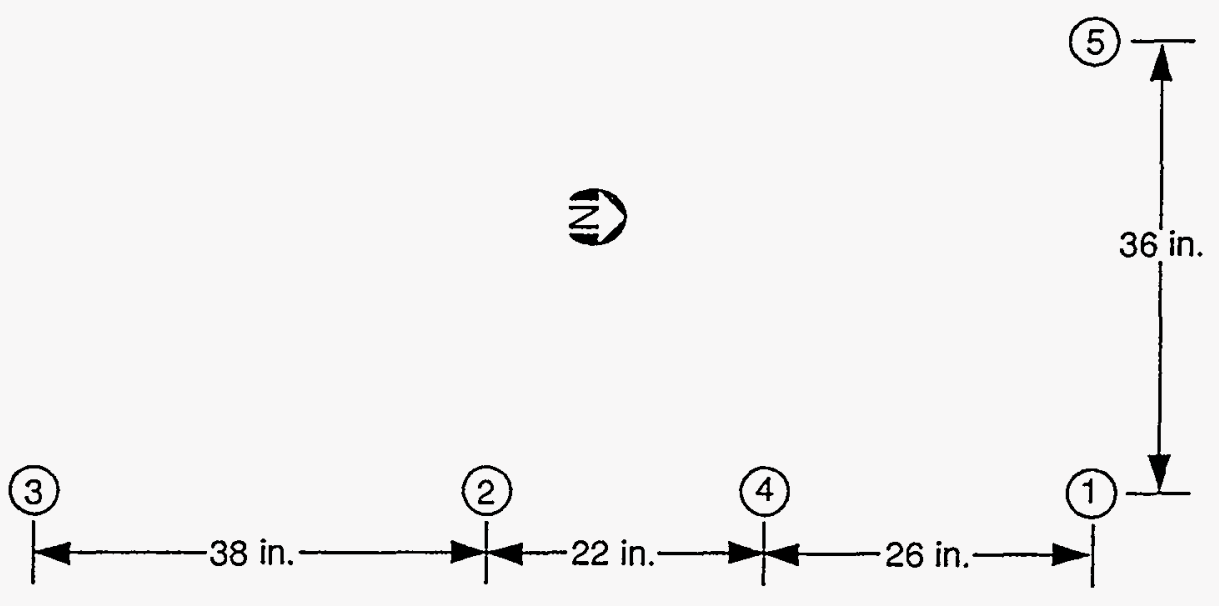

X94 0412

Figure 19. Spacing and order of application for field trials.

The five grout columns were examined by exposing a face and then destructively removing the columns using a standard backhoe in an intact a manner as possible. Figure 20 shows the exposed face with the edge of the grout columns 1 through 4 exposed, with the extreme right column being column 1 as shown schematically on Figure 19 . Figure 20 shows that the grout wall was nearly tied together; however, there was soil space of several inches between columns. Although Figure 20 leaves the impression that the columns were well resolved and cylindrical, tendrils of grout extended as much as $3 \mathrm{ft}$ from the central column for each of the grout columns; therefore, there was some "tying" of columns together. Columns $1,2,4$, and 5 were comprised of a solid central column of soil/grout mix with a diameter of between 20 and 28 in. Figure 21 details column 4 and clearly shows the solid nature of the column and the roughly $5-\mathrm{cm}$ withdrawal frequency on the edge of the column. Figure 22 shows the top of column 1 and 4-9/16-in. drill hole plug at the top of the column. Column 1 with the 1:1 Portland/water mix by volume resulted in the hardest and most intact soil column. By contrast, soil column 5 , shown in Figure 23 was the largest (28 in. average diameter), but with a 1:1 Portland/water mix by mass was considerably more brittle. Soil column 3 shows an interesting phenomenon involving a plugged injector hole. A "cork-screw" shaped grout column resulted as shown in the cross section in Figure 24. There were alternating layers of soil and grout caused by plugging of one of the two injectors at the end of the drill stem. This plugging is caused by drilling through the compacted silty clay soils without keeping a small trickle of water through the injector during the drilling operation. All further holes used a small amount of water injection during the drilling operation to keep the injector clear of debris. Number 3 was the hole in the field trials in which a thin-walled spiral wrapped tube was placed for the demolition grout. An application of the BRISTAR 150 product produced dramatic fracturing of the entire grout column. Figure 25 shows fracture lines in the "cork screw" shaped grout column. There was considerable expansion in the spiral wrapped tube as shown in Figure 26, which is a cross section of the spiral wrapped tube from hole 3 . The entire column was highly fractured into 3 to 6-in. grout blocks and easily broken apart using a hand shovel. The other grout columns could not be fractured using a hand shovel alone but were easily pulled out of the digface using a standard backhoe. For the intact columns $(1,2,4,5)$, up to $3 \mathrm{ft}$ lengths of the column could be removed intact with the backhoe operation. 


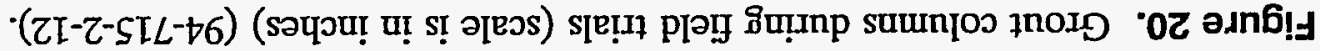

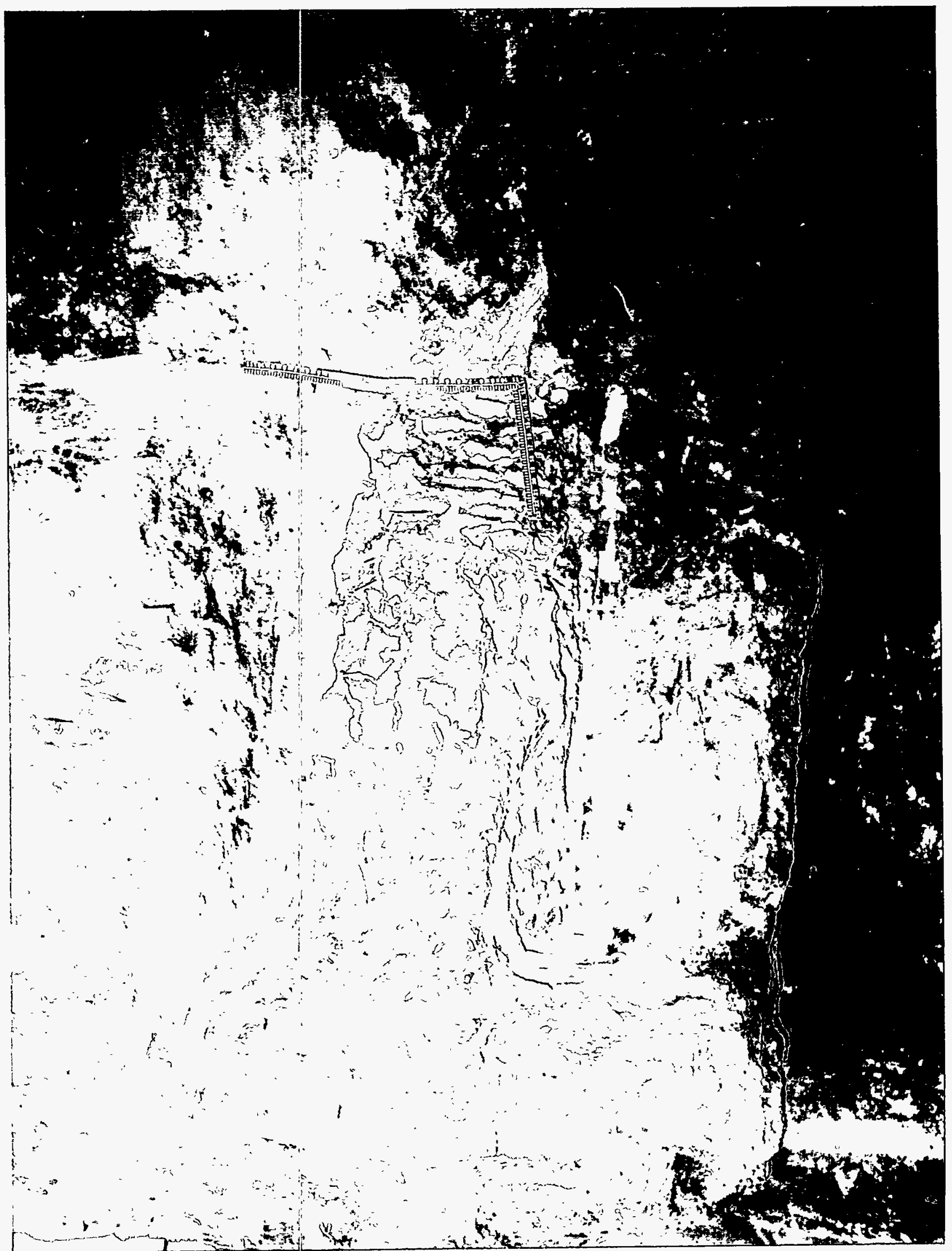





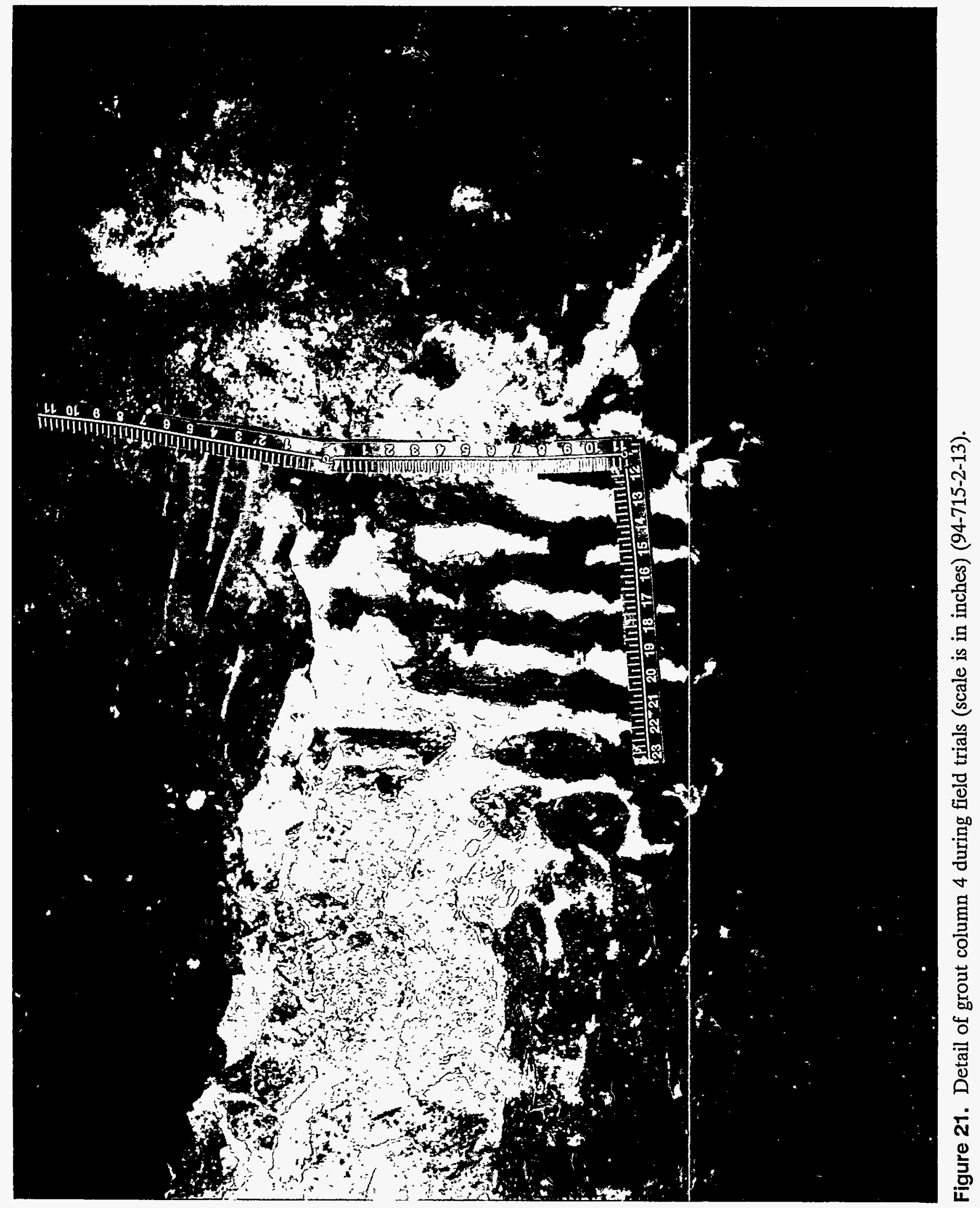


. 


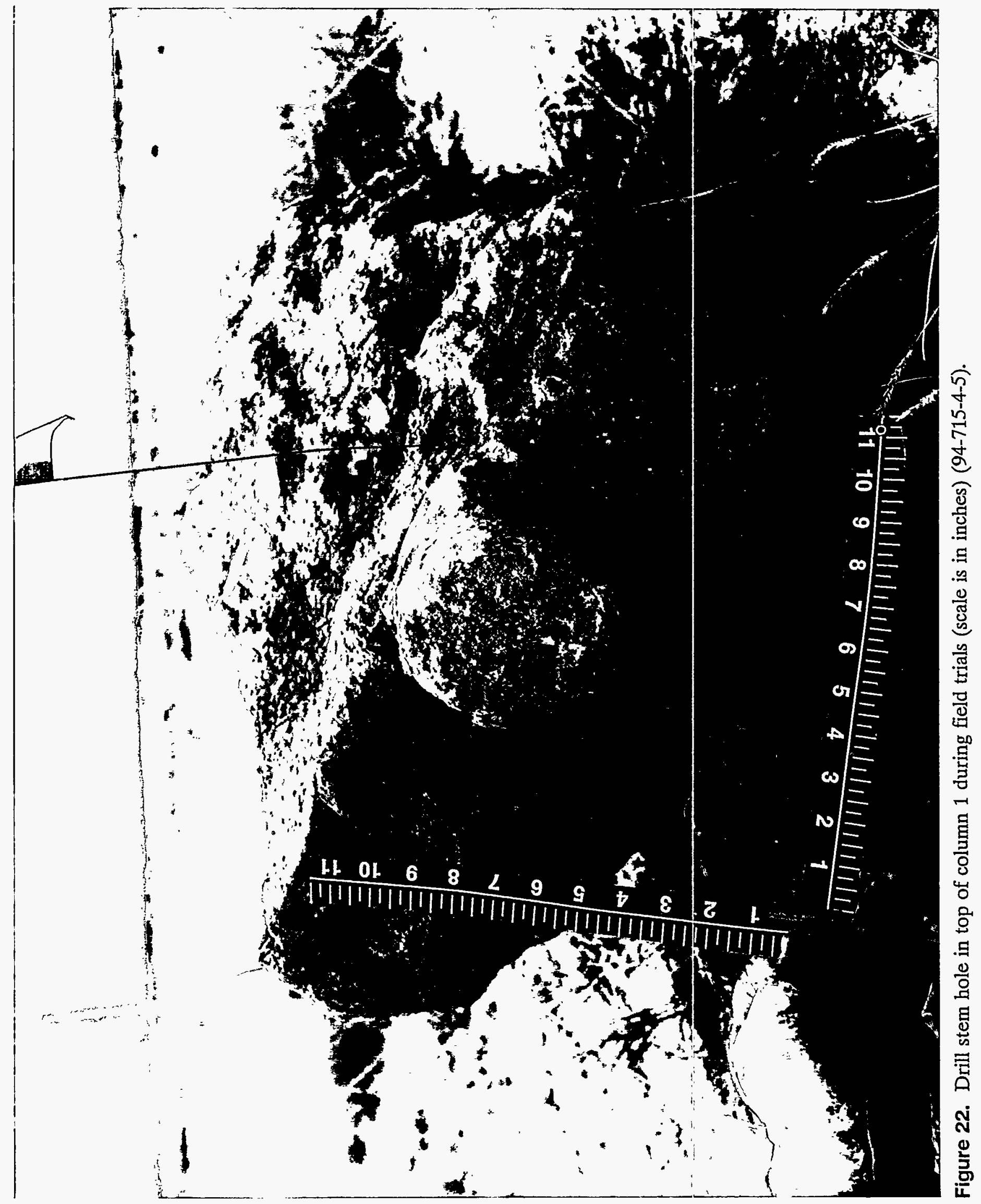





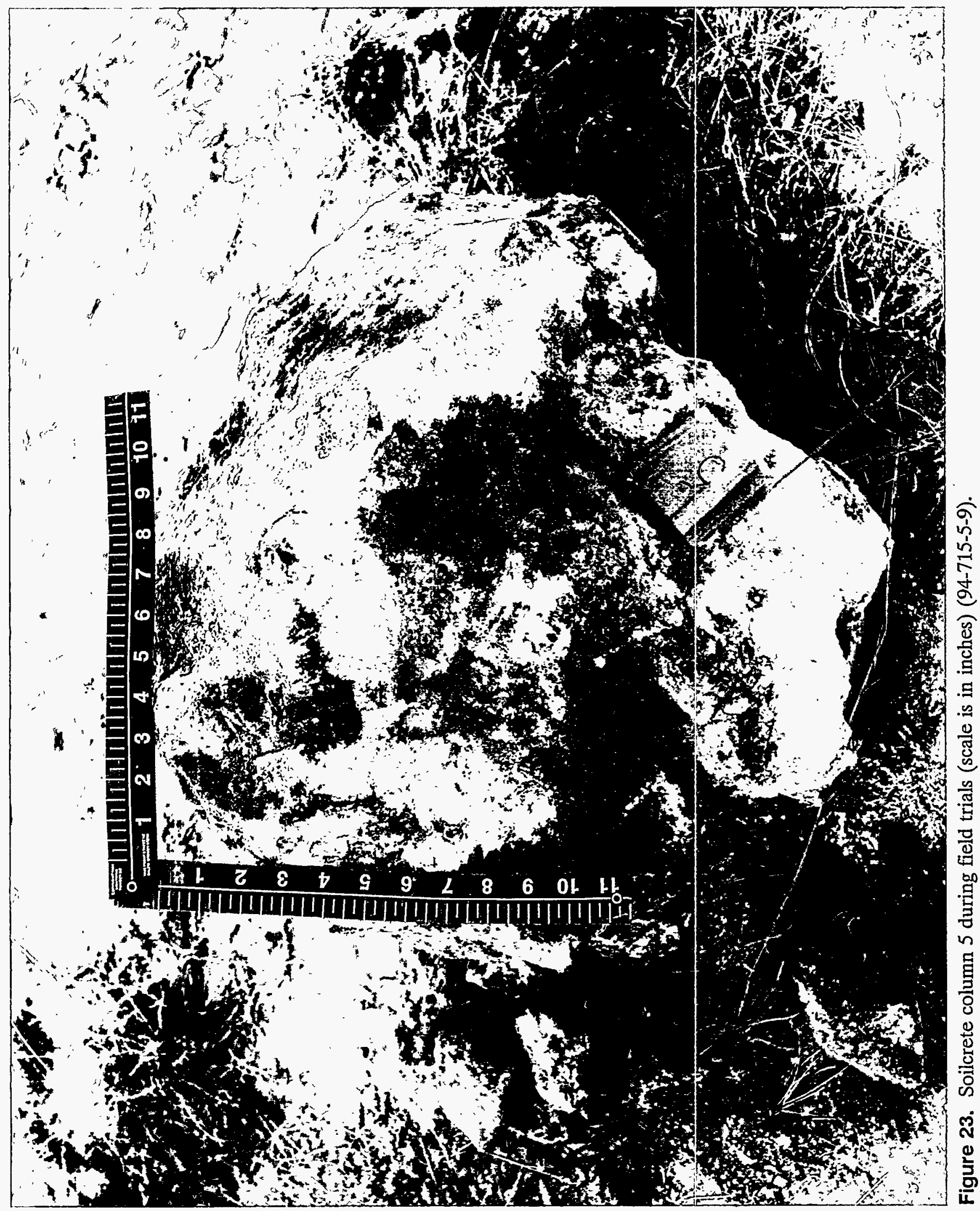





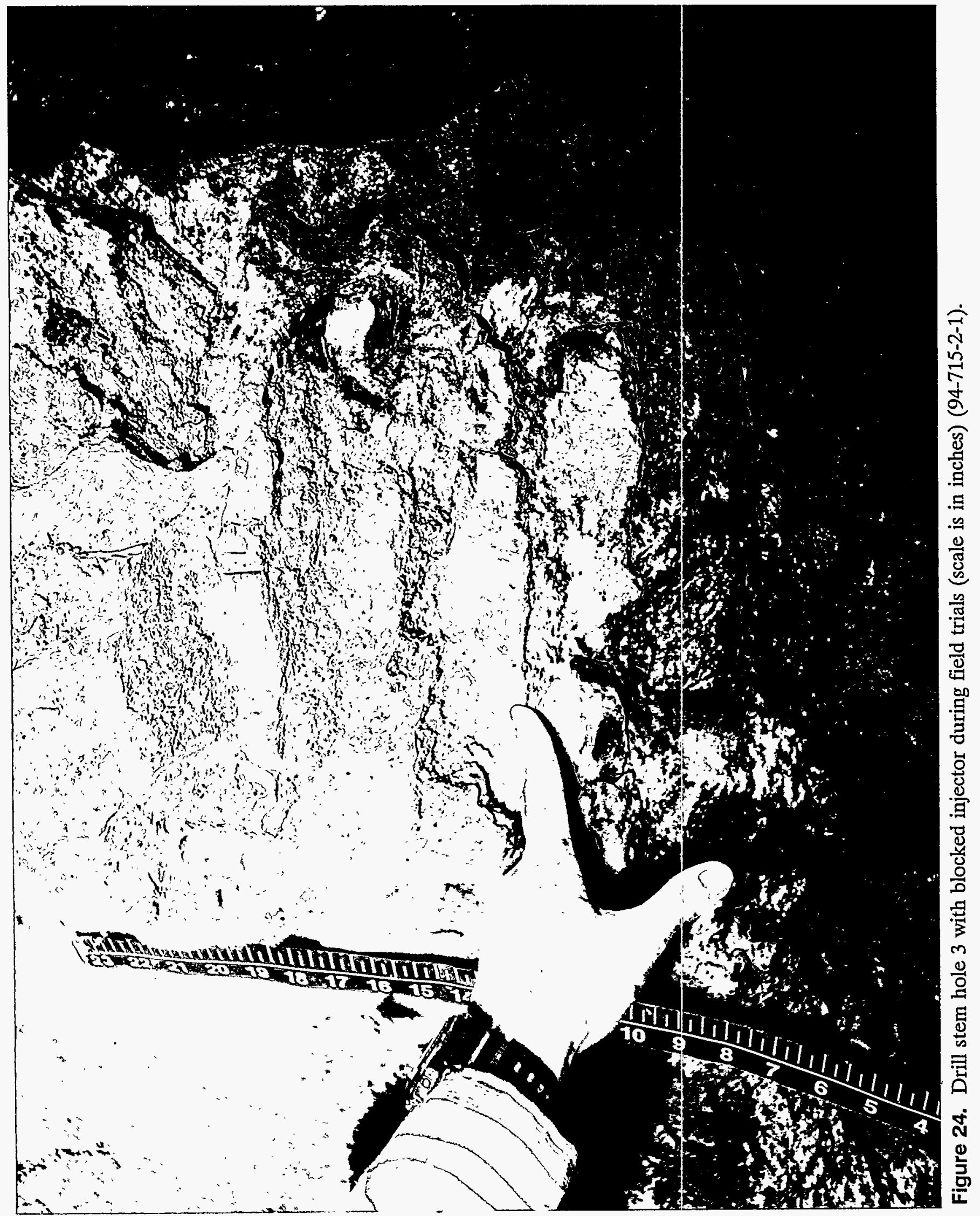





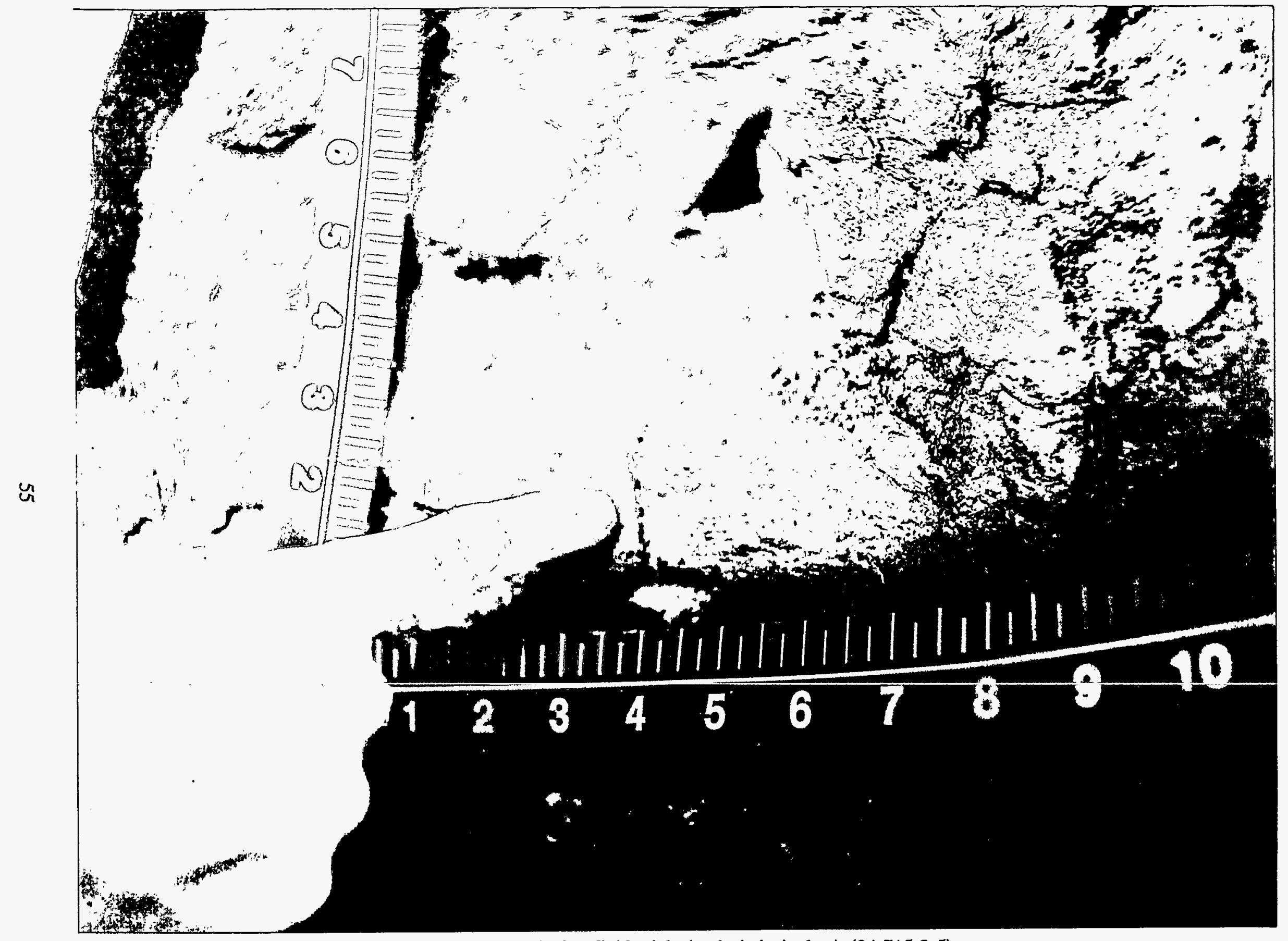

Figure 25. Fracture caused by BRISTAR in hole 3 during field trials (scale is in inches) (94-715-2-5). 



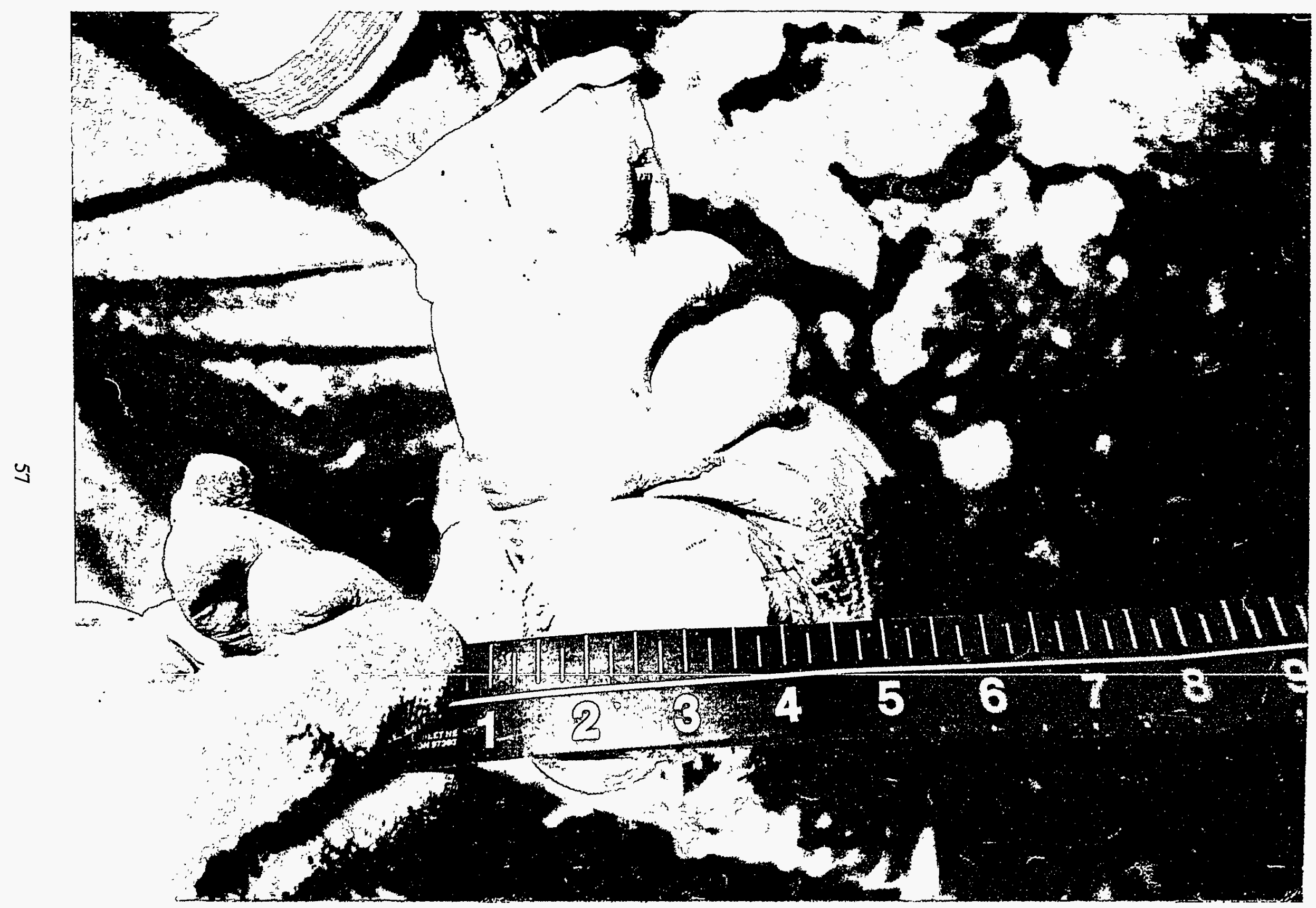

Figure 26. Expansion of BRISTAR tube during field trials (scale is in inches) (94-715-4-15). 

In summary, the field trials provided needed background information on the grout mix, drill stem withdrawal rate, and pressure of application of the demolition grout. These field trials showed a positive proof of concept that the jet grouting operation could be performed in the fine silty clays of the INEL soil and that columns as large as 28 in. in diameter could be created.

\subsection{Grouting}

In the grouting phase of the experiment, a total of 36 holes in a triangular matrix were successfully jet grouted without producing any contaminant spread. A total volume of $24.0 \mathrm{yd}^{3}$ of a 1:1 Portland/water mix on a mass basis was injected into the confines of a $10 \times 10 \times 10$-ft pit containing a soil/waste matrix without an accompanying volume increase in the pit. This volume of injected grout means that there was a void space, representing $65 \%$ of the volume of the pit, filled with the injected grout material.

\subsubsection{Grouting Efficiency}

In this first application of jet grouting to a heterogeneous waste pit, the application of the grout spanned 3 days involving jet grouting the $10 \times 10 \times 10-\mathrm{ft}$ matrix with a total of 36 grout holes. Table 3 gives a drilling/grouting history for the entire demonstration. The average time to drill the hole in the pit was 1.75 minutes with many of the holes requiring only 1 minute to drill. The application of the grout (withdrawal of the drill stem) took an average of 7 minutes. The average overall time to process a single hole took about $\mathbf{4 0}$ minutes including set up time for the grout, drill positioning, drilling, grouting, and clean-up. The average grout injected per hole was $0.67 \mathrm{yd}^{3}$; however, for the first hole a total of $4.5 \mathrm{yd}^{3}$ of grout was injected. Hole 1 was located in the extreme southwestern corner of the pit and was the location of a series of random dumped drums containing all of the different types of waste. The strategy on the first hole was to grout a position until a surge of grout came up the grout collection pit around the drill stem. Grout was injected until seepage started and then a programmed withdrawal was initiated ( 6 seconds for each $5 \mathrm{~cm}$.). All other grout holes followed the prescribed 6 seconds for each $5 \mathrm{~cm}$ unless seepage was observed overflowing the collection pit.

\subsubsection{Seepage/Overflow Observations}

A total of approximately $1 \mathrm{yd}^{3}$ emanated from the 36 total grout holes. A 3-ft deep L-shaped . spoils pit was created on the west and south ends of the pit to collect any seepage from the grout holes as shown in Figure 27. During the field trials, the final grout formulation (hole 5) had only a 1-gal quantity of seepage, and it was thought that a simple collection pit of about a 2-gal capacity around the drill stem would be sufficient to contain any seepage. The larger spoils pit shown in Figure 27 was dug only as insurance against any unexpected seepage emanating from the grout holes and for convenience because once the grouting was started it would have been inconvenient to reposition the CASA GRANDE drill system and dig a needed pit. After each grout hole was jet grouted, the amount of spoils was recorded in the Innovative Grout/Retrieval Demonstration logbook based on a visual estimate of the grout emission from the hole. A copious amount of grout was emitted from only two of the grout holes. When grouting hole 7, copious amounts of grout/sludge material emanated from hole 6, and when grouting hole 25, hole 24 (see Figure 7 for map of the grouted pit) also showed grout ejection. Hole 6 was about $4 \mathrm{ft}$ from hole 7 and had been grouted 
Table 3. Drilling/grouting log.

\begin{tabular}{|c|c|c|c|c|}
\hline Hole & Date & $\begin{array}{c}\text { Drill } \\
\text { insertion time } \\
\text { (minute) }\end{array}$ & $\begin{array}{c}\text { Jet } \\
\text { grouting time } \\
\text { (minute) }\end{array}$ & $\begin{array}{c}\text { Grout take } \\
\left(y d^{3}\right)\end{array}$ \\
\hline 1 & $7 / 7-7 / 8$ & 10 & 75 & 4.5 \\
\hline 2 & $7 / 8$ & 3 & 6 & \\
\hline 3 & $7 / 8$ & 1 & 8 & \\
\hline 4 & $7 / 8$ & 3 & 8 & 7.0 \\
\hline 5 & $7 / 8$ & 2 & 7 & (avg $0.88 \mathrm{yd}^{3}$ \\
\hline 6 & $7 / 8$ & 1 & 7 & per hole) \\
\hline 7 & $7 / 8$ & 2 & 5 & \\
\hline 8 & $7 / 8$ & 2 & 9 & \\
\hline 9 & $7 / 8$ & 1 & 4 & \\
\hline 10 & $7 / 9$ & 1 & 7 & \\
\hline 11 & $7 / 9$ & 3 & 6 & \\
\hline 12 & $7 / 9$ & 1 & 7 & 4.5 \\
\hline 13 & $7 / 9$ & 1 & 8 & (avg $0.64 \mathrm{yd}^{3}$ \\
\hline 14 & $7 / 9$ & 1 & 7 & per hole) \\
\hline 15 & $7 / 9$ & 2 & 1 & \\
\hline 16 & $7 / 9$ & 3 & 6 & \\
\hline 17 & $7 / 9$ & 1 & 5 & \\
\hline 18 & $7 / 9$ & 1 & 4 & 3.5 \\
\hline 19 & $7 / 9$ & No data & No data & (avg $0.58 \mathrm{yd}^{3}$ \\
\hline 20 & $7 / 9$ & No data & No data & per hole) \\
\hline 21 & $7 / 9$ & No data & No data & \\
\hline 22 & $7 / 9$ & No data & No data & \\
\hline 23 & $7 / 11$ & 1 & 3 & \\
\hline 24 & $7 / 11$ & 1 & No data & \\
\hline 25 & $7 / 11$ & 1 & 2 & \\
\hline 26 & $7 / 11$ & 1 & 2 & \\
\hline 27 & $7 / 11$ & 1 & 3 & \\
\hline 28 & $7 / 11$ & 1 & 1 & 4.5 \\
\hline 29 & $7 / 11$ & 2 & 2 & (avg $0.32 \mathrm{yd}^{3}$ \\
\hline 30 & $7 / 11$ & 1 & 6 & per hole) \\
\hline 31 & $7 / 11$ & 1 & 1 & \\
\hline 32 & $7 / 11$ & 1 & 2 & \\
\hline
\end{tabular}


Table 3. (continued).

\begin{tabular}{|c|c|c|c|c|}
\hline Hole & Date & $\begin{array}{c}\text { Drill } \\
\text { insertion time } \\
\text { (minute) }\end{array}$ & $\begin{array}{c}\text { Jet } \\
\text { grouting time } \\
\text { (minute) }\end{array}$ & $\begin{array}{l}\text { Grout take } \\
\left(y d^{3}\right)\end{array}$ \\
\hline 33 & $7 / 11$ & 1 & No data & \\
\hline \multirow{2}{*}{34} & $7 / 11$ & 2 & 2 & \\
\hline & $7 / 11$ & 2 & 1 & \\
\hline \multicolumn{5}{|l|}{$35 / 36$} \\
\hline 37 & $7 / 11$ & 1 & 5. & \\
\hline \multicolumn{5}{|c|}{$\frac{\text { Totals }}{\text { Average time for drillin } \sigma=175 \text { minutes }}$} \\
\hline $\begin{array}{l}\text { Averag } \\
\text { Averag } \\
\text { Total g } \\
\text { Averag } \\
\text { Total a }\end{array}$ & $\begin{array}{l}\text { drilling }= \\
\text { grout }= \\
=24.0 \text { yd } \\
\text { ke per ho } \\
\text { te per hol }\end{array}$ & process $=40 \mathrm{mir}$ & & , \\
\hline
\end{tabular}

within 15 minutes of hole 6 , so, the grout had virtually no set time. The consistency of the grout that emanated from the pit was a mixture of the Portland cement and the sludge material (vegetable oil, kitty litter, and Micro Cel-E, an absorbent) as shown in Figure 28. The estimated amount of sludge that came out of hole 6 was $1 / 8 \mathrm{yd}^{3}$. This same phenomena of a sludge/grout mixture emanating from an adjacent hole occurred when injecting hole 25 . When injecting hole 25 , copious amount of sludge/grout mixture emanated from hole 24. The matrix in Figure 7 shows that holes 6, 7, 24, and 25 all lie in the same region of the pit. This region had an abundance of sludge drums and greatly affected the jet grouting process. It is speculated that the sludge material with extremely fine void space was mixed poorly, and the Portland cement simply pushed this material (like an incompressible fluid) up the adjacent drill holes. The adjacent holes contained only a spiral wrapped tube with a metal fence post in the top to counter the buoyancy effect. A sample of the grout/sludge mixture was set aside and hydrated to form a solid block indicating that the vegetable oil/Micro Cel-E mixture did not preclude forming a wastecrete solid block. For about one-half of the holes, the 1 to 2-gal spoils pit around the drill stem was sufficient to contain the emanating grout mixture. In the other half, up to 4-gal of material emanated from the hole and flowed through interconnecting shallow (6 in. deep) predug trenches to the large spoils pit as shown in Figure 29. Management of the emanated grout in these trenches was simple because the viscosity of the grout and flow rate were low. The emanated grout at the top of the pit in the spoils holes around the grout holes set up in a matter of a few hours and formed a hard crust that was easy to work around when drilling and grouting other positions. On several occasions, personnel from the Westinghouse Hanford Company easily broke out the curing crust in these flow channels and stored the solid debris in the large spoils pit. During drilling, total refusal occurred in hole 35 at about $4 \mathrm{ft}$. The drill bit was visibly smoking when withdrawn indicating impaction on either a solid metal object or a solid grouted box. Later examination during the retrieval phase indicated that this position was the edge of a solid grouted box full of metal scrap (this box is discussed further in the retrieval section). 


\subsubsection{Volume Increase in the Pit During Grouting}

Using the laser level systems (standard surveyed equipment $\pm 1 / 2$ in.), no upward movement of the pit occurred during the jet grouting phase. Two laser systems were located on the top of the pit and checked after each grout application, and no change in the top level of the pit occurred.

\subsubsection{Void Filling}

Based on the data, the total voids accessed by the grout equals about $67 \%$ of the physical volume based on the dimensions of the pit. A total of $24 \mathrm{yd}^{3}\left(648 \mathrm{ft}^{3}\right)$ of Portland cement was injected into the pit, which had a injectable volume of $972 \mathrm{ft}^{3}$ (the depth of the region grouted was about $9 \mathrm{ft}$ deep with a top surface cross sectional area of about $\left.108 \mathrm{ft}^{2}\right)$. This indicates that there was intense mixing of soil and Portland cement occurred under the jet grouting action and that the "soilcrete" mix readily accessed voids in the waste forms.

In summary, $24 \mathrm{yd}^{3}$ of Portland cement was successfully jet grouted via 36 holes into a nominal $10 \times 10 \times 10$-ft matrix of heterogeneous waste and soil. The average time per hole was 40 minutes including set-up and clean-up time. Details on the air monitoring and contaminant spread associated with this process is included in Section 3.7, Air Monitoring.

\subsection{Demolition Grout}

The use of demolition grout to fracture the waste and ease the burden on the retrieval apparatus was found to be highly temperature dependent. The contact surface temperature of the bottom of each of the grout holes (down through the spiral wrapped tubes) was found to continuously decrease after grouting as the stored energy in the soil/soilcrete/waste seam was transferred to the cooler outer walls as shown on Table 4. Exothermic heat of hydration caused the temperatures of the monolith to be as high as $140^{\circ} \mathrm{F}$ (see Table 4). Over a 1-week period, however, most of the temperatures of the pit were well below $95^{\circ} \mathrm{F}$, the maximum applicable temperature for the BRISTAR 100 product. Measuring the bottom of the grout holes with a contact mercury bulb thermometer was thought to be a valid representation of the grout block based on the field trials experience. During the field trials, the bottom contact temperature of the field trials hole 3 (the one in which demolition grout was applied) was measured to be $63^{\circ} \mathrm{F} 5$ days after jet grouting, and the corresponding demolition grout for that temperature range was applied. For this application the grout worked well as previously discussed. During the Cryogenic Retrieval Project, ${ }^{5}$ temperatures of undisturbed INEL soil at the $10 \mathrm{ft}$ depth were measured to approach $60^{\circ} \mathrm{F}$. This represents a good heat sink for the curing monolith, and therefore, when the bottom of the hole in the subject demonstration measured 70 to $90^{\circ} \mathrm{F}$, it was thought that most of the monolith was at those temperatures. This was further supported by the field trial temperature measurement $\left(63^{\circ} \mathrm{F}\right)$ in which good fracturing of the entire column occurred using the bottom temperature measurement as a guide. Two types of BRISTAR demolition grout were applied: (1) BRISTAR 100 with an applicable temperature range of 60 to $95^{\circ} \mathrm{F}$ (applied to 15 holes starting from the west edge of the pit working toward the center) and (2) BRISTAR $100 \mathrm{~S}$ with a temperature range of 96 to $122^{\circ} \mathrm{F}$ (applied to three holes). The procedure of working from one end to the other was followed, at the direction of a BRISTAR representative, because of the potential for blowouts caused by steam generation in the spiral wrapped tubes from the heat of hydration as the BRISTAR cured. After applying BRISTAR 


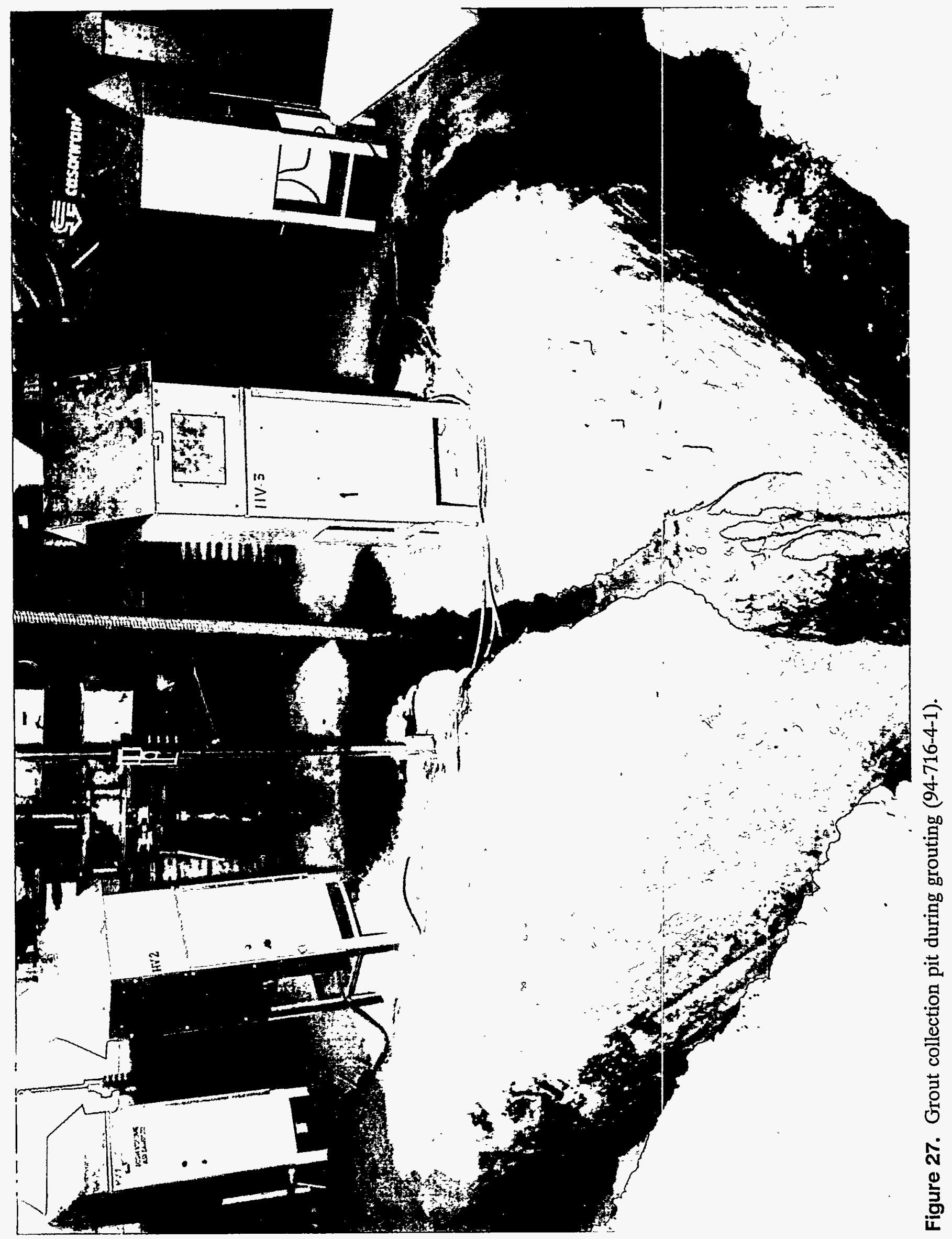





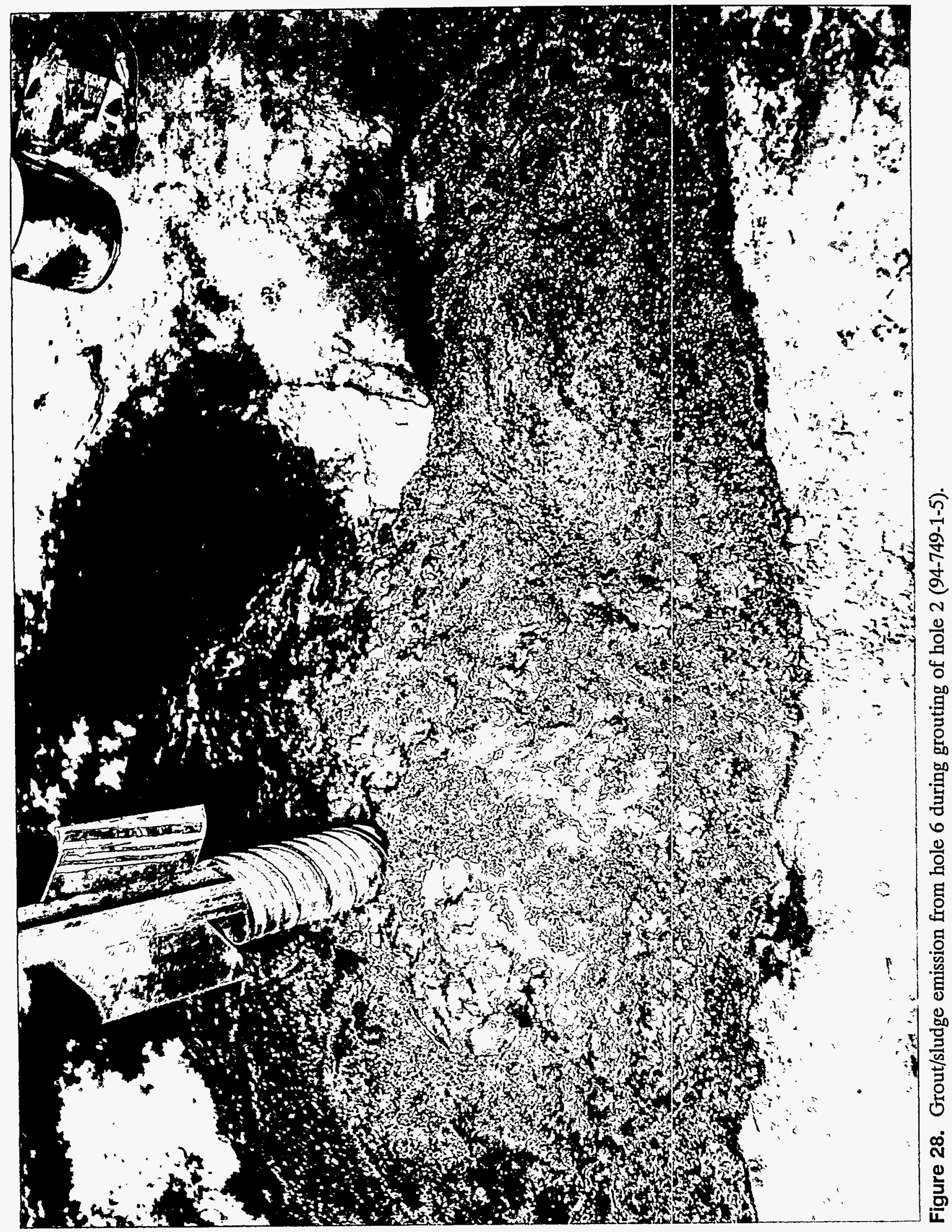


$-\cdots$ 


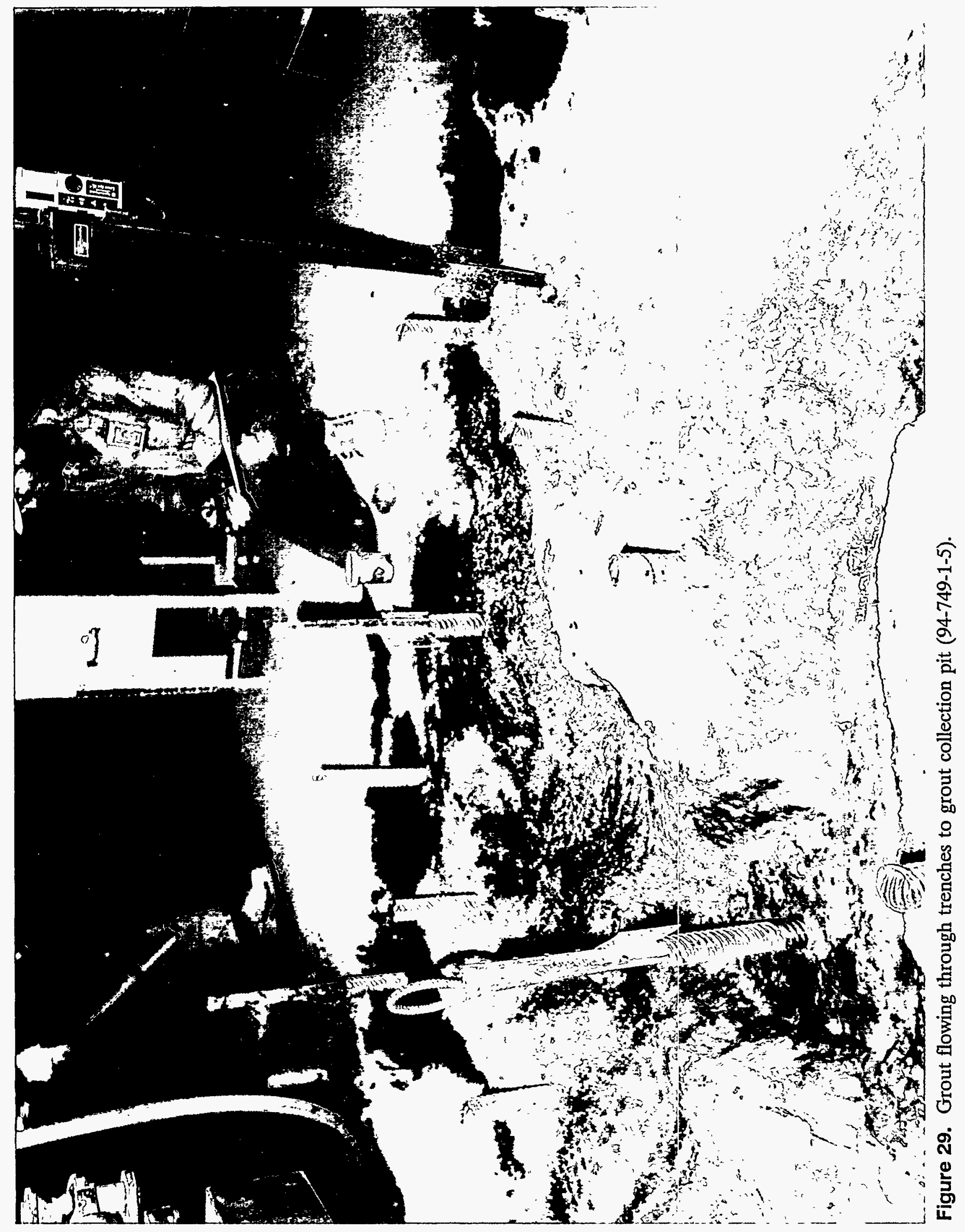


Table 4. Contact temperature history of the bottom pit.

\begin{tabular}{|c|c|c|c|}
\hline Hole & $7 / 12 / 94$ & $7 / 14 / 94$ & $7 / 18 / 94$ \\
\hline 1 & 94 & 82 & 71 \\
\hline 2 & 83 & 78 & 78 \\
\hline 3 & 68 & 72 & 76 \\
\hline 4 & 81 & 70 & 70 \\
\hline 5 & 91 & 81 & 82 \\
\hline 6 & 111 & 112 & 108 \\
\hline 7 & 135 & 122 & 112 \\
\hline 8 & 128 & 122 & 120 \\
\hline 9 & 88 & 81 & 82 \\
\hline 10 & 70 & 73 & 73 \\
\hline 11 & 80 & 78 & 76 \\
\hline 12 & 78 & 70 & 71 \\
\hline 13 & 100 & 85 & 85 \\
\hline 14 & 98 & 90 & 84 \\
\hline 15 & 89 & 90 & 86 \\
\hline 16 & 106 & 98 & 101 \\
\hline 17 & 112 & 108 & 104 \\
\hline 18 & 78 & 70 & 74 \\
\hline 19 & 78 & 79 & 75 \\
\hline 20 & 80 & 80 & 80 \\
\hline 21 & 119 & 108 & 102 \\
\hline 22 & 84 & 80 & 80 \\
\hline 23 & 78 & 77 & 78 \\
\hline 24 & 111 & 100 & 100 \\
\hline 25 & 72 & 74 & 76 \\
\hline 26 & 82 & 82 & 84 \\
\hline 27 & 103 & 92 & 92 \\
\hline 28 & 140 & 108 & 110 \\
\hline 29 & 102 & 94 & 90 \\
\hline 30 & 82 & 78 & 80 \\
\hline 31 & 75 & 72 & 76 \\
\hline 32 & 74 & 78 & 78 \\
\hline 33 & 77 & 80 & 82 \\
\hline 34 & 107 & 90 & 90 \\
\hline 35 & 114 & 120 & 118 \\
\hline 36 & 96 & 87 & 85 \\
\hline
\end{tabular}


in about 15 tubes, the first of 12 blowouts occurred. The area was evacuated and the blowouts proceeded in other holes. It became apparent that the temperature range had been exceeded at some axial position in the tubes and that a different grade of BRISTAR should be applied. Before the first blowout, BRISTAR $100 \mathrm{~S}$ with a temperature range of 96 to $122^{\circ} \mathrm{F}$ was applied to holes 6 , 16, and 17. The higher temperature grade BRISTAR was used in these holes because of slightly elevated measured temperatures (see Table 4). No blowouts occurred in the holes. The blowouts occurred over a period of 2.5 hours and one such occurrence is shown in Figure 30 . Three and onehalf hours after the first blowout, the weather shield was entered and "hanging" temperature measurements of the center of the pit were taken in empty holes 14 and 37, which confirmed that the appropriate temperature had been exceeded with temperatures of 130 and $105^{\circ} \mathrm{F}$, respectively. These same holes had bottom contact temperatures of 84 and $85^{\circ} \mathrm{F}$ respectively. The next day, the hanging temperature of remaining holes was taken and recorded on Table 5. This further confirmed the hypothesis that the midline temperature of the pit was much hotter than the extremities and temperatures as high as $126^{\circ} \mathrm{F}$ were measured. BRISTAR 100 s with the higher temperature range was applied without incident to all of the tubes. Before application of the BRISTAR 100S product, a visual inspection of the top surface of the pit showed considerable expansion and cracking of the top surface near holes 6,16 , and 17 further suggesting that the BRISTAR 100S product should work. For those holes that suffered blowout, the tube was usually clear of debris to the 6 to $8 \mathrm{ft}$ depth indicating that the blowout occurred in the middle regions axially in the pit. The BRISTAR 100S product was applied with the thin plastic liners for these positions. No blowouts occurred for any of the BRISTAR 100S products applied on Friday, July 22, 1994. On the following Monday, July 25, 1994, a visual inspection of the pit showed considerable cracking and expansion of the thin-walled tubes on top of the pit. There were visible cracks up to 1 in. across in the top cap spoils emanating from some tubes further supporting the idea that the BRISTAR had fractured the monolith.

\subsection{Retrieval}

A standard backhoe retrieval technique was successfully used to remove the grouted monolith. This section discusses the details of that retrieval and monolith characteristics, efficiency of the BRISTAR demolition grout, evaluation of the formation of "shadows," and incomplete grouting. Retrieval involved creating an access pit similar to that used during the Cryogenic Retrieval Demonstration $^{5}$ and chipping debris from the monolith with the teeth of the backhoe. Retrieval was accomplished in a series of five campaigns with two retrieval baselines also established for comparison purposes. The north half of the pit was retrieved during the first four retrieval campaigns, and the south half of the pit was retrieved in a final retrieval campaign. The baseline retrievals were performed in soil only to compare dust loading on the air monitors for the grouted monolithic block removal operations and operations more akin to removing debris in soil only. Table 6 summarizes the time of operation of each of the retrieval campaigns and a total time to retrieve the entire pit was 4 hours and 48 minutes of actual operation. The retrievals were accomplished in the five campaigns to allow filter changeout for the air monitoring equipment. The basic technique for debris removal involved placing the backhoe 8 to 10 in. into the face on top of the pit and applying a downward or cutting force on the monolith. This process is illustrated sequentially in Figures 31 and 32. The leading edge of the backhoe sliced through the overburden soil and caused this soil to spill over the monolith into the access pit followed by flaked off portions of the monolith. As a result, there was considerable mixing of the overburden soil with the monolithic portions in the access pit. Further mixing and tearing of the larger monolithic portions occurred when the backhoe was 


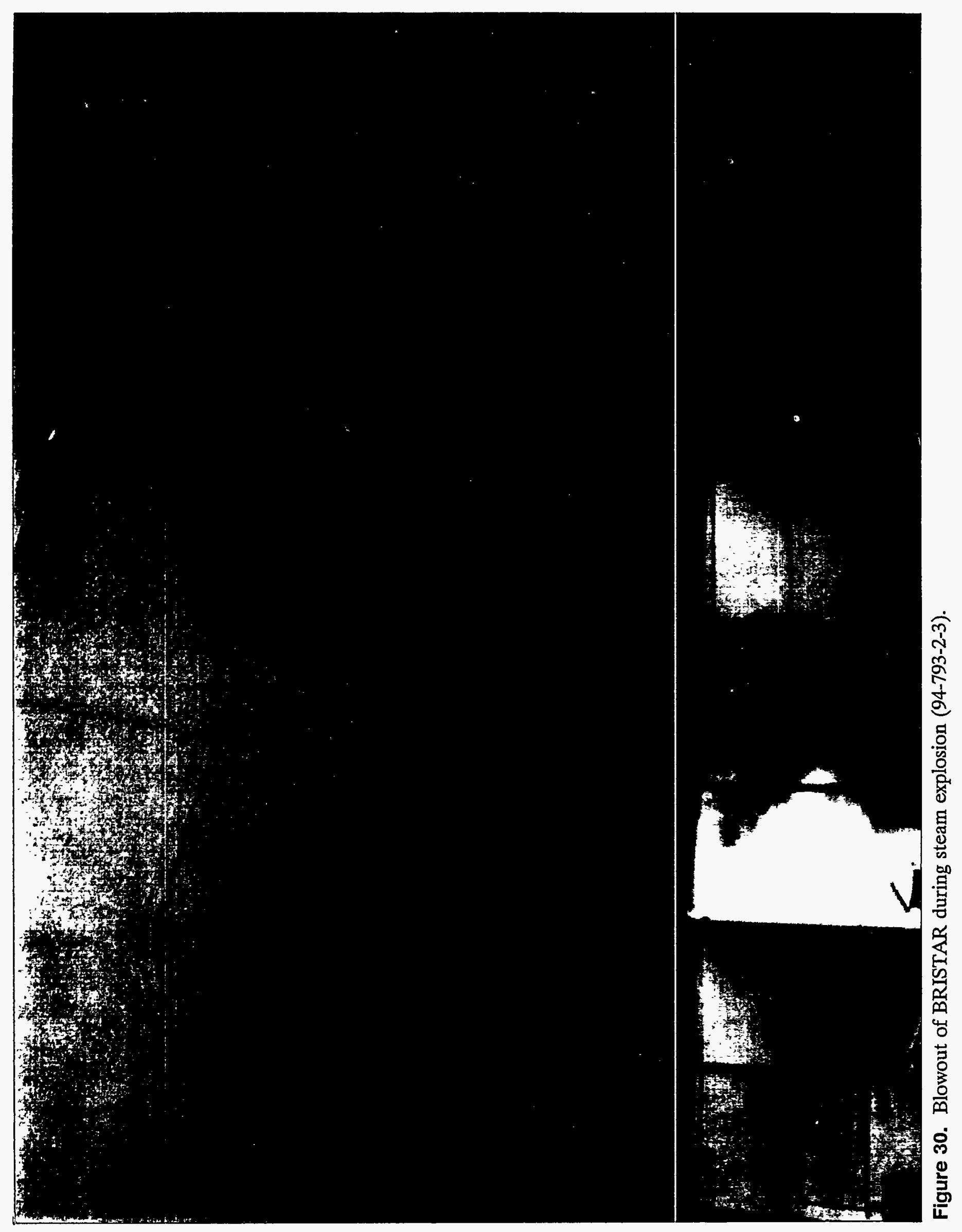



Table 5. Temperature of mid point on the monolith using a digital hanging thermocouple.

\begin{tabular}{lc}
\hline Hole & $\begin{array}{c}\text { Temperatures } \\
(7-22-94)\end{array}$ \\
\hline 37 & 106 \\
13 & 122 \\
30 & 105 \\
12 & 95 \\
22 & 89 \\
9 & 101 \\
36 & 107 \\
21 & 113 \\
28 & 121 \\
5 & 122 \\
3 & 101 \\
14 & 102 \\
26 & 108 \\
\hline & 126 \\
\hline
\end{tabular}

used to "clean out" the access pit. The backhoe operator would chip, pound, and flake away the overburden and monolith until a considerable pile accumulated in the access pit. When enough waste was accumulated to fill one or two waste boxes, the waste remedial action was started. The overburden soil around the grout hole and the actual grout hole leading to the monolith are shown schematically in Figures 33 and 34. Large (1.5 to $2 \times 0.5 \mathrm{ft}$ ) solid portions of soilcrete were flaked off the digface in each of these retrieval steps.

\subsubsection{Monolith Characteristics}

The monolith was comprised of several different textures depending upon the waste container and soil structure around the containers. The appearance of the debris in the digface was one of drums and boxes encased in the soilcrete mix with a mostly solid monolith structure.The retrieval phase was performed up to 2 weeks after grouting and the soilcrete portions of the pit were still warm to the touch and appeared to be curing but hydrated concrete. High humidity was associated with the digface. There were three distinct types of materials encountered in the monolith: (1) large regions of solid soilcrete mix with no waste; (2) regions of loose waste interred in soilcrete (formerly in cardboard containers); and (3) regions of metal drums or cardboard boxes with internal high concentrations of Portland cement as opposed to the general soilcrete mixture observed throughout the pit. No waste was encountered that did not have complete encapsulation by the soilcrete or 
Table 6. Retrieval operations for the innovative grout/retrieval demonstration.

\begin{tabular}{|c|c|c|}
\hline Retrieval baselines & Time & Comments \\
\hline BR-1 & 120 minutes & $\begin{array}{l}\text { Baseline retrieval; used backhoe bucket in soil } \\
\text { digging/dumping operation during creation of access } \\
\text { pit. Under large tent. }\end{array}$ \\
\hline BR-2 & 30 minutes & $\begin{array}{l}\text { Used front end loader of backhoe in soil } \\
\text { digging/dumping operation at entrance to small tent. } \\
\text { Five-minute dig and dump cycle with dry soil. }\end{array}$ \\
\hline \multicolumn{3}{|l|}{ Monolith retrieval } \\
\hline R-1 & 49 minutes & Removed first 2 rows 9 grout holes; filled and removed. \\
\hline R-2 & 9 minutes & $\begin{array}{l}\text { Run aborted after } 9 \text { minutes due to external dust } \\
\text { storm; } 2 \text { boxes of debris removed. }\end{array}$ \\
\hline R-3 & 91 minutes & $\begin{array}{l}\text { Extracted } 4 \times 4 \times 4 \text {-ft box full of metal and } 55 \text {-gal } \\
\text { drum encased in soilcrete. Five boxes of debris } \\
\text { removed. }\end{array}$ \\
\hline $\mathrm{R}-4$ & 57 minutes & $\begin{array}{l}\text { Extracted drums with computer paper and concrete. } \\
\text { Squared up pit for BWID site tour; removed } 4 \text { boxes of } \\
\text { debris. }\end{array}$ \\
\hline R-5 & 91 minutes & $\begin{array}{l}\text { Removed remainder of monolith under small tent; } \\
\text { sludge drums uncovered. Debris piled outside of tent. }\end{array}$ \\
\hline
\end{tabular}

Portland cement directly; however, there were several examples of intact encapsulated waste that broke apart upon retrieval. Material such as concrete cinder blocks, computer paper, and cloth exhibited the property that when retrieved, the encapsulating grout easily broke off and left the material exposed to the air. For the case of loose debris such as cloth, paper, wood, small metal (less than 6 in. in any dimension), and sludge, removal of the debris was relatively easy and could be accomplished by applying a downward force of the backhoe bucket on the top the monolith. However, for a banded box filled with metal debris, it took over 1 hour of vigorous digging by dropping the backhoe bucket on and around the box to exhume the object. The main problem encountered for this object was the presence of metal debris embedded in the soilcrete. The backhoe bucket would strike a metal object and bounce off to lower positions. Upon close examination of the digface, a 4-in. wide $\times 1$-ft long piece of 1/4-in. plate steel was embedded lengthwise across the top of the box in the soilcrete. This plate was preventing the backhoe teeth from penetrating the box. Eventually, the backhoe bucket was able to get behind the box and pull the debris apart. When an encapsulated drum or box was pulled from the face, intact waste material would pull away from the encapsulating soilcrete leaving piles of waste and large (6 in., $2 \mathrm{ft}$ ) chunks of soilcrete in the access pit as shown on Figure 35. Figure 36 shows the general monolithic nature of the pit during retrieval and overall high moisture content of the surrounding soils. Much of the soil observed on 


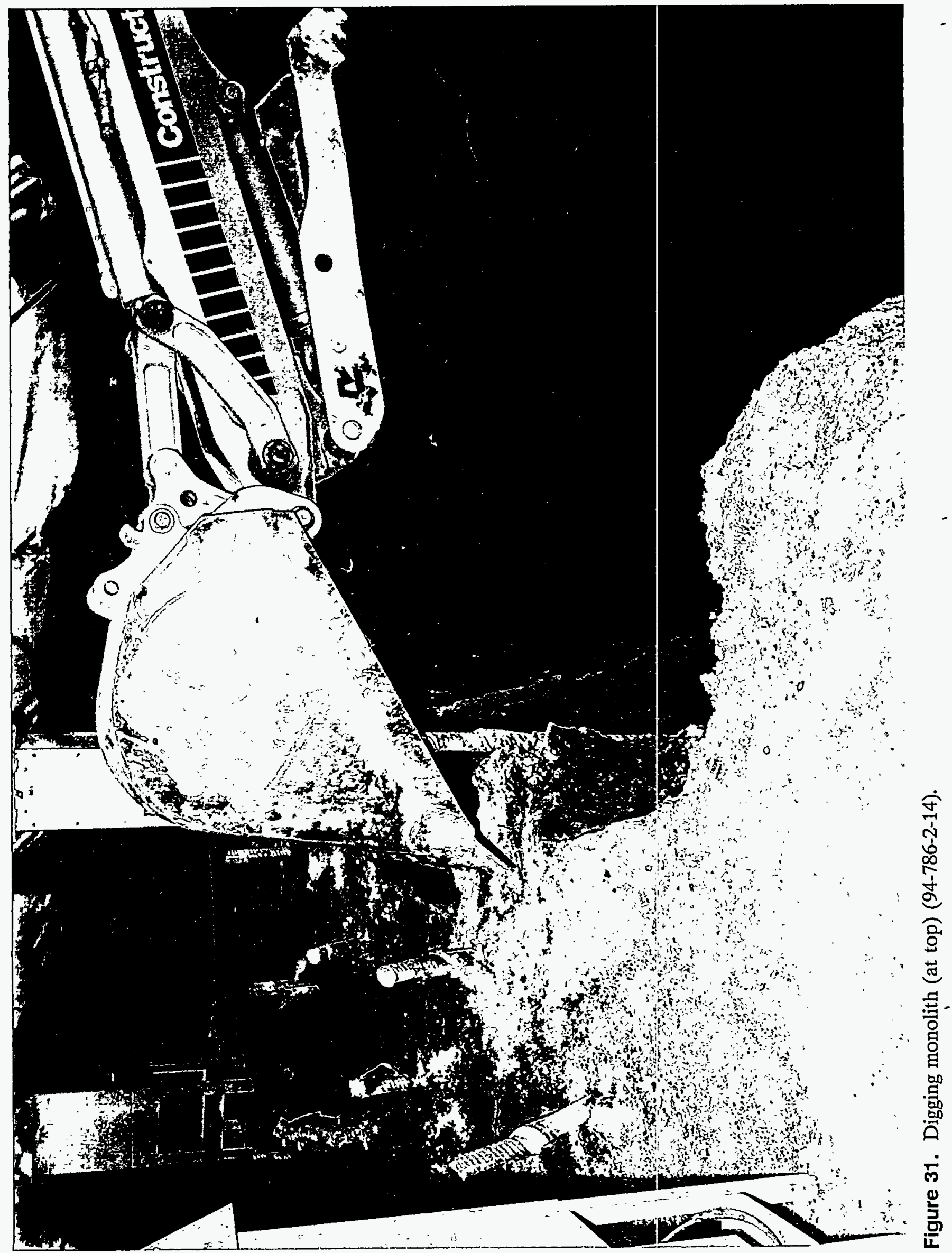




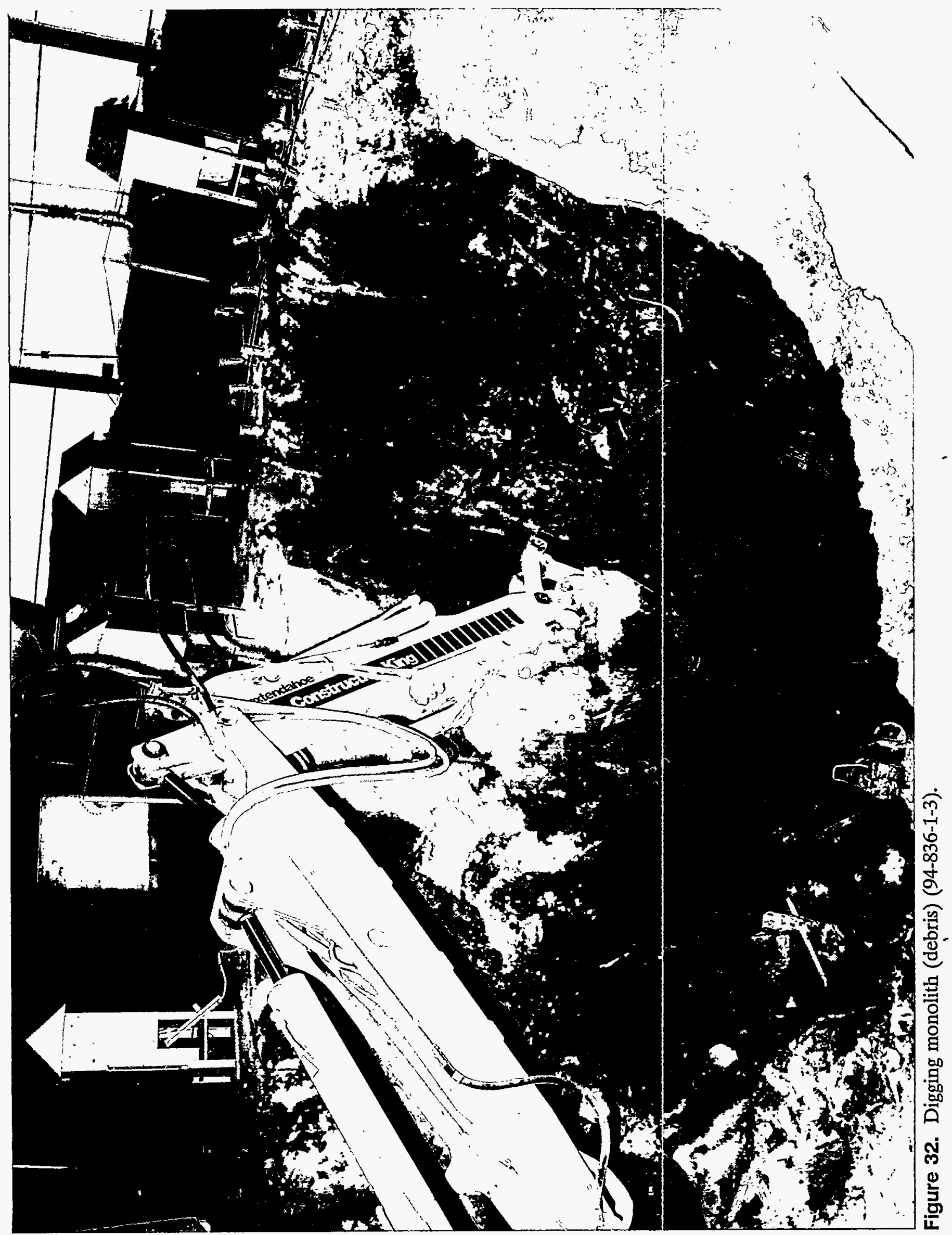


• 


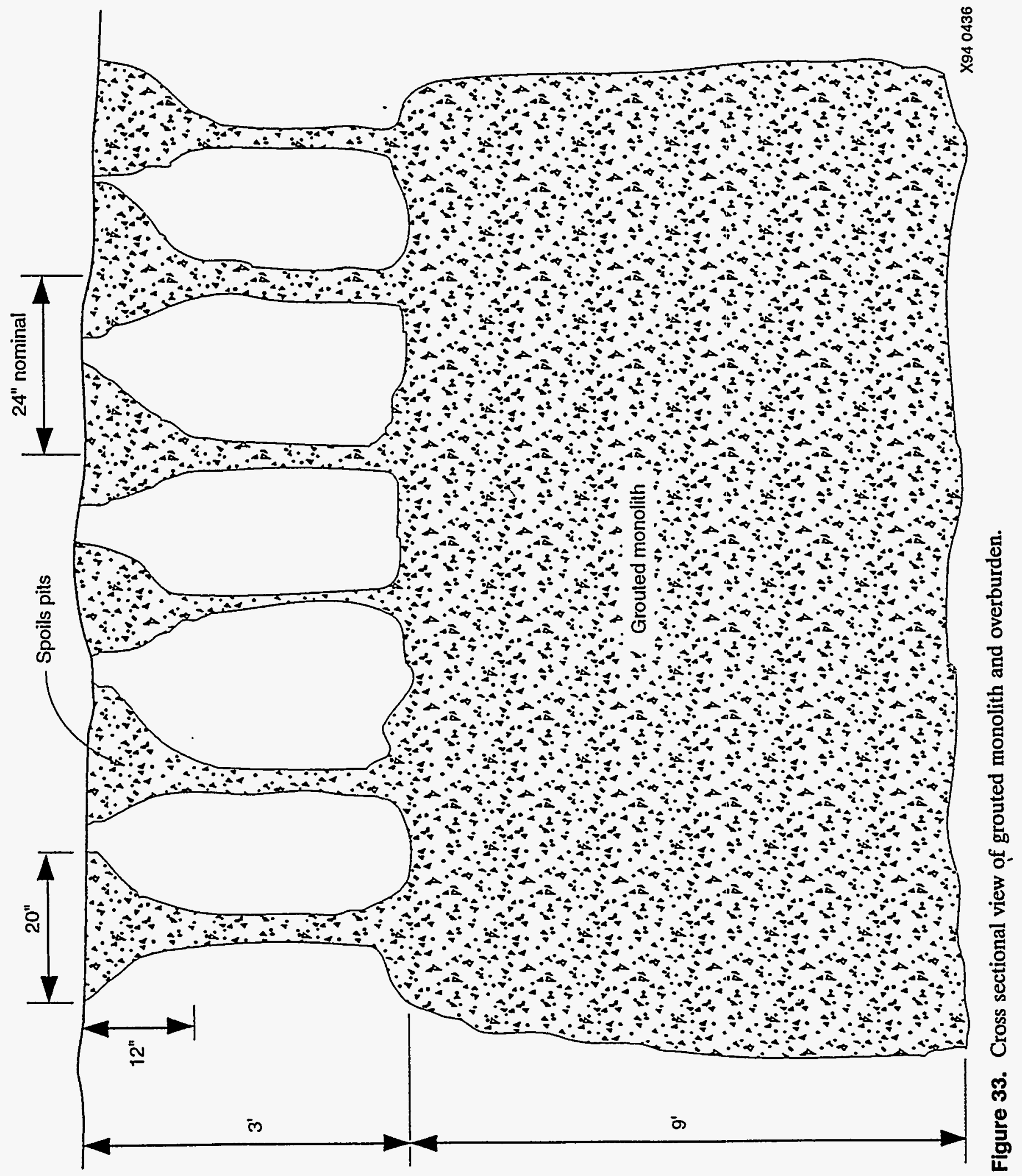


. 


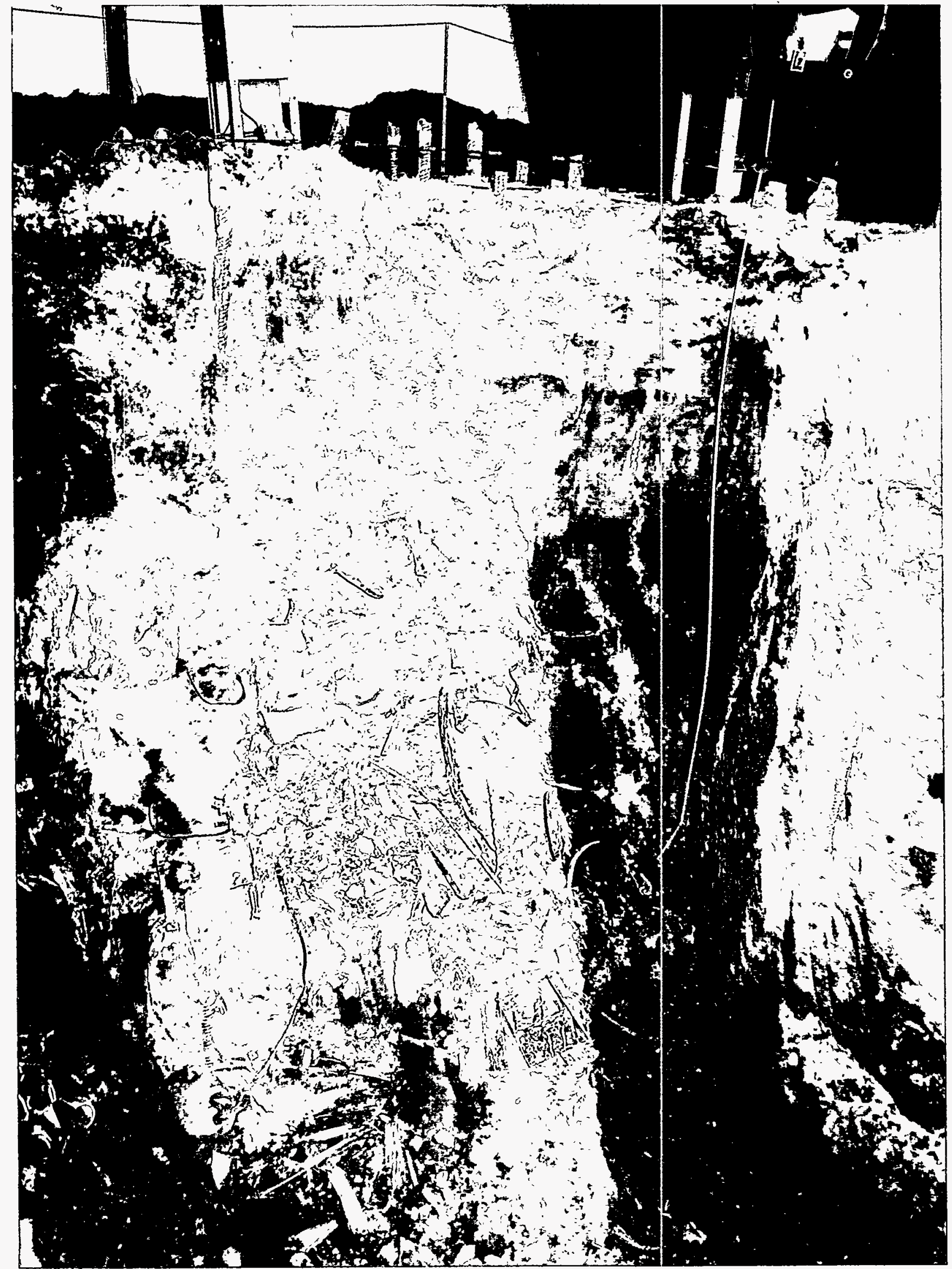

Figure 34. Grout hole/overburden/monolith during retrieval (94-836-1-10). 



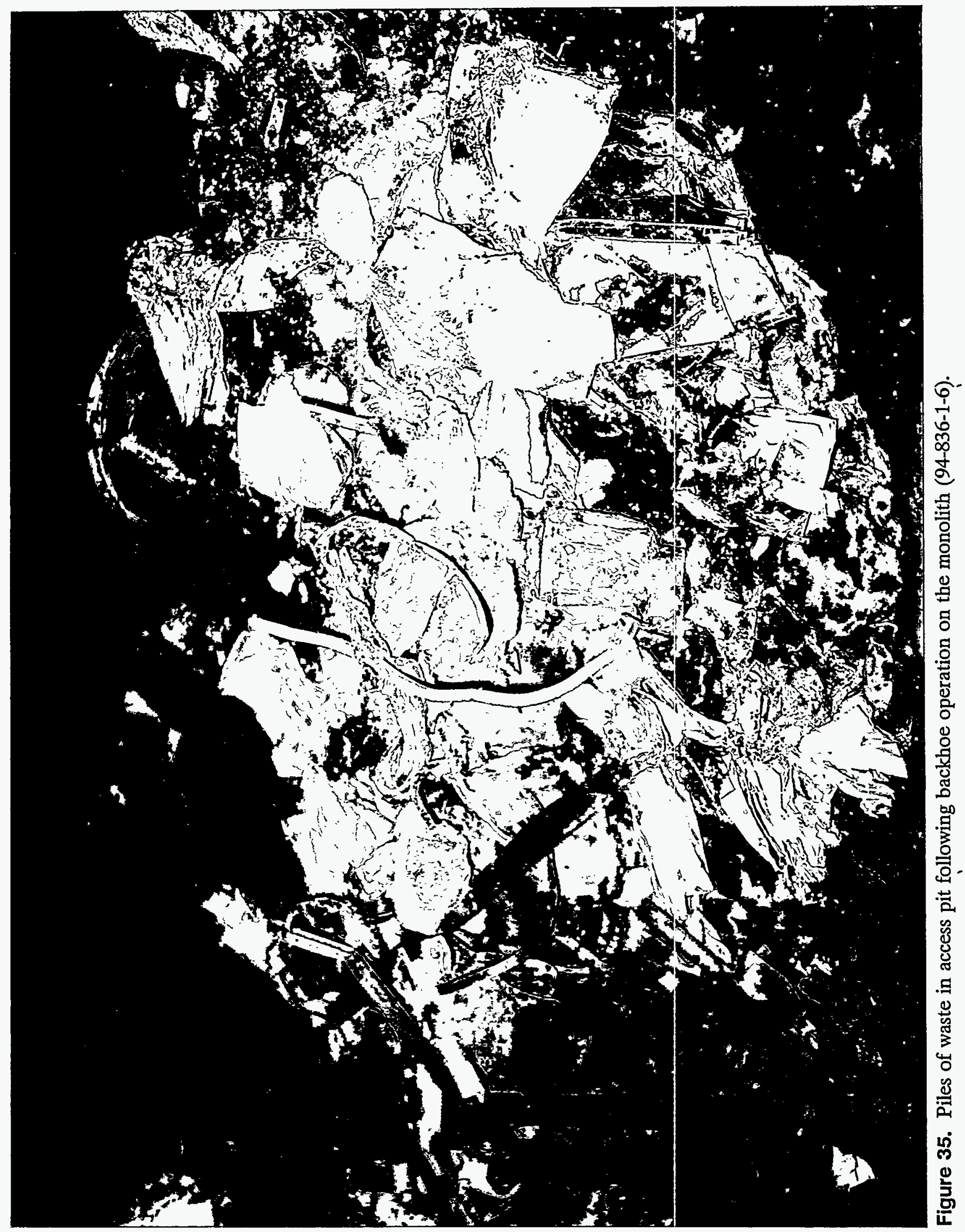


$-$ 


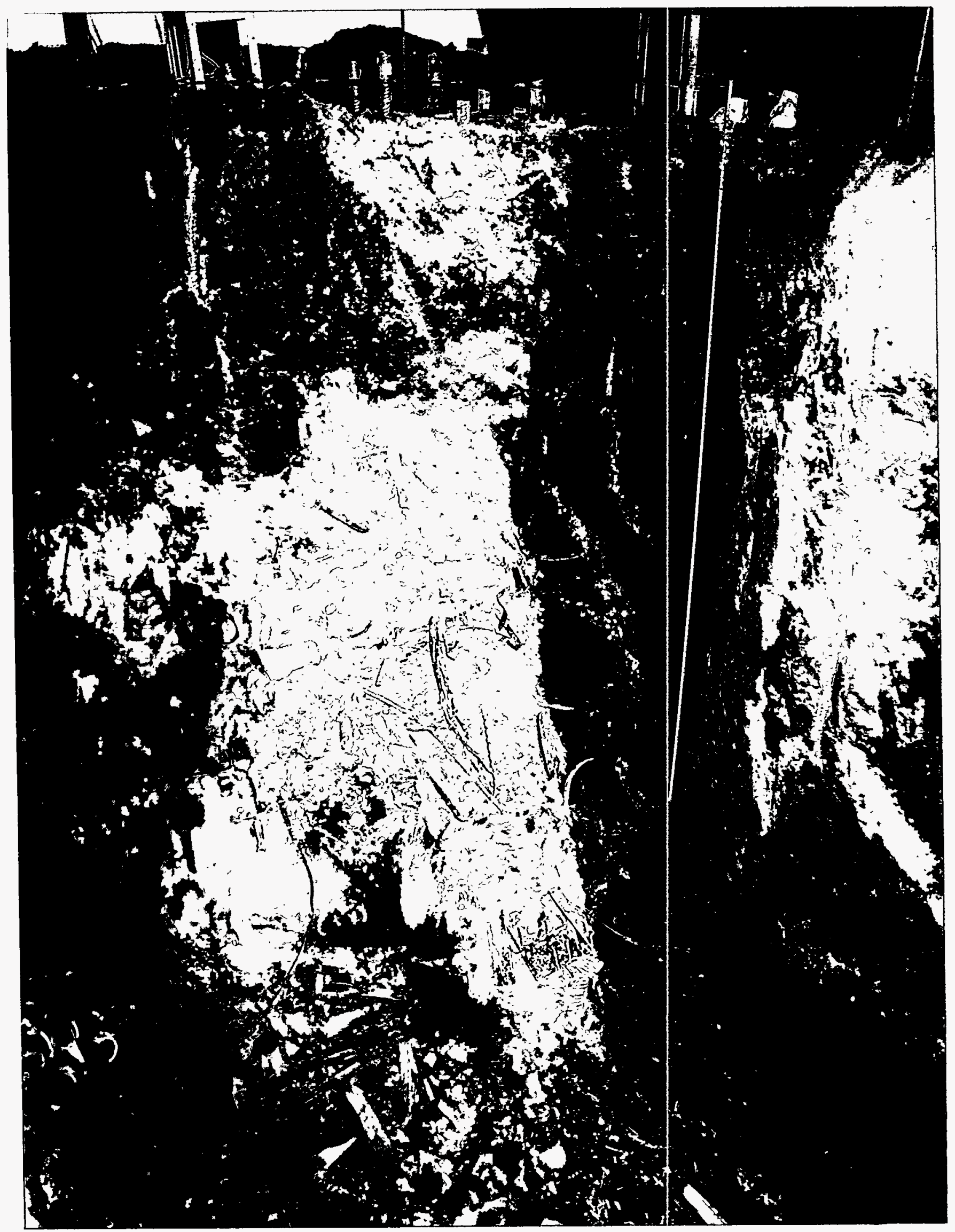

Figure 36. General view of exposed monolith (94-836-1-1). 

the monolith in Figure 36 fell into the pit from the overburden and should not be confused with pockets of soil. The top surface of the overburden was very dry following the vigorous foot traffic encountered during the demolition grout application and the various blowouts. In fact, the BRISTAR upon blowout formed a dry powder (consisting primarily of calcium oxide and other in organic compounds) that also covered the top of the pit and this material sluffed into the pit during retrieval and covered the monolith. The lighter colored areas in Figure 36 are ledges of the drier overburden soil at the angle of repose. Figures 37 through 39 are pictures of the monolith taken in direct sunlight before emplacing the "small" tent for the final retrieval campaign. The solid nature of the monolith is apparent and identifiable waste material is protruding from the digface. For the case of a metal drum continuing plastic (waste container 25-see Table 1), the drill hole punctured the drum and completely encased all interior material in a mostly Portland cement matrix. Figure 40 shows the drum locked into the monolith, completely encased in soilcrete, and Figure 41 shows the drum following the action of pulling the drum out of the monolith with the backhoe. The imprint of the drum case was left in the monolith indicating complete encapsulation. The drum was sectioned with a large cement saw showing that the interior of the drum was completely encapsulated with mostly Portland cement with small regions (5\%) of the surface area of the cut with soil or soilcrete inclusions. Figure 42 clearly shows complete drum penetration and filling with grout including the small 1/8-in. space between the drum and drum liner. Figure 43 shows the light brown colored areas of soilcrete with the darker grey areas of almost pure Portland cement. Also shown in Figure 43 is the thin-walled spiral wrapped tube that penetrated the drum. This metal container was removed from the digface by prying the backhoe teeth into the soilcrete above and behind the drum. The drum literally "popped" out of the digface. Figure 44 shows several typical items removed from the pit including grouted channel iron and 4-mil plastic drum liners and cardboard containers.

\subsubsection{Efficiency of BRISTAR Demolition Grout}

After minimal digging on the monolith, it became apparent that the BRISTAR did not expand as demonstrated during the field trials. Virtually all of the tubes interior to the monolith did not expand, and therefore, no fracturing occurred during the demonstration. This explains some of the difficulty reported in the previous section on retrieving the box of material; however, the breakaway strength of the grout material was low enough that a standard backhoe could remove it. Because of the failure of the BRISTAR to fracture the waste, an attempt was made to redrill it out the previous grout holes and reapply the BRISTAR in the now cooler pit in the southern half of the pit before the final retrieval campaign. This action was based on the assumption that the high axial temperature gradient shown in Tables 3 and 4 caused the BRISTAR to fail. One theory is that the BRISTAR $100 S$ product did not expand because the temperature of the tube while curing was actually too cold. When applying the BRISTAR 100 S product (following the blowouts discussed earlier), ice water was used to ensure that no further blowouts occurred. The ice water $\left(39^{\circ} \mathrm{F}\right)$ may have locally cooled the region of the tube below the minimum temperature for the product and curing with no expansion occurred. It was previously reported that there was considerable fracturing of the top surface of the pit and the spiral wrapped tubes protruding out the top of the pit. This could have been caused by summer temperatures and natural circulation heat transfer heating the tube up to the cure point. Based on this analysis, a rock drill was used to drill through the monolith with a total of four holes being placed in the pit to a depth of $3 \mathrm{ft}$ and the BRISTAR special product was applied. Before drilling the holes, the top overburden was removed leaving the monolithic block exposed. Figures 45 and 46 show two of the holes 24 hours after the application of the BRISTAR with considerable 
fracturing of the monolith, which indicates that if the temperature is correct, BRISTAR can be used for this application.

\subsubsection{Formation of "Shadows" and Incomplete Grouting}

There was no direct evidence of "shadows" caused by the presence of solid (rigid) waste form and only a few examples of incomplete soil/grout mixing. There was only one observed region that suggested a zone that had not been grouted. This region was a lens of soil about $2 \mathrm{ft}$ thick, $3 \mathrm{ft}$ long, and $2 \mathrm{ft}$ wide. It occurred in the southwest quarter of the pit (north and east of hole 1) and within about $2 \mathrm{ft}$ of the bottom of the pit. This lens of moist soil was completely encapsulated in grout. There were no surrounding objects to suggest a shadow effect (a shadow was postulated to occur as a metal container shielded a region from the jet grouting action). Throughout the pit, there were small irregular shaped pockets of moist soil completely surrounded by the soilcrete mix. The size of these pockets varied but averaged (based on visual observation) about 3 to 4 in. in diameter and $1 \mathrm{ft}$ long. Based on visual observation during the various retrieval phases, these soil pockets occurred in only $10 \%$ of the volume of the monolith. The soil pockets and large lens of soil were very moist (20\% soil moisture by mass estimate based on visual observations of previous laboratory testing in INEL soil).

\subsection{Dust Control/Contamination Control}

Airborne dust and tracer concentrations were measured for all major phases of the demonstration including the grouting and retrieval phases. In addition, concentrations for baseline retrievals of soil only and a general static background were established. In this section, comparisons of the measured concentrations for the grouting phase are made to a static background. Also, concentrations measured for the retrieval phase are compared to baseline values. Data were collected with HI VOL samplers. The filters in the samplers were weighed before and after data collection. This mass of dust was divided by the volume of air that was measured to pass through the filter resulting in a dust concentration in grams per liter. The INEL Environmental Chemistry Laboratory analyzed the filter for concentration of praseodymium using ICP-MS and reported it as micrograms of tracer per gram of soil per cubic foot of air on the filter or parts per million per cubic feet of air. In addition to the air sampling, during the grouting phase, smears of the drill stem and samples of the spoils (grout that emanated out the top of a hole during grant injection) were analyzed for concentration of tracer. The overall estimated uncertainty for this measurement technique is $\pm 20 \%$. Table 7 gives a summary of the air monitoring data. In Table 7, the mean values of up to 8 samplers are given with a 2-sigma standard deviation. Represented on Table 7 are grouting phase tests G-1 through G-7, static background, baseline retrievals 1 and 2 and retrieval tests R-1 through R-5. Appendix $\mathrm{C}$ contains the data for each of the individual samplers and gives a figure showing the sampler location relative to the pit. A discussion of each of these testing phases relative to dust and tracer measurement are given below.

\subsubsection{Background}

A background concentration of dust and praseodymium oxide were measured with a 120 -minute sampling period as summarized on Table 7. The average dust concentration during a period of no physical activity under the large tent was $5.12 \mathrm{E}-8 \mathrm{~g} / \mathrm{L}$ and the praseodymium concentration was 


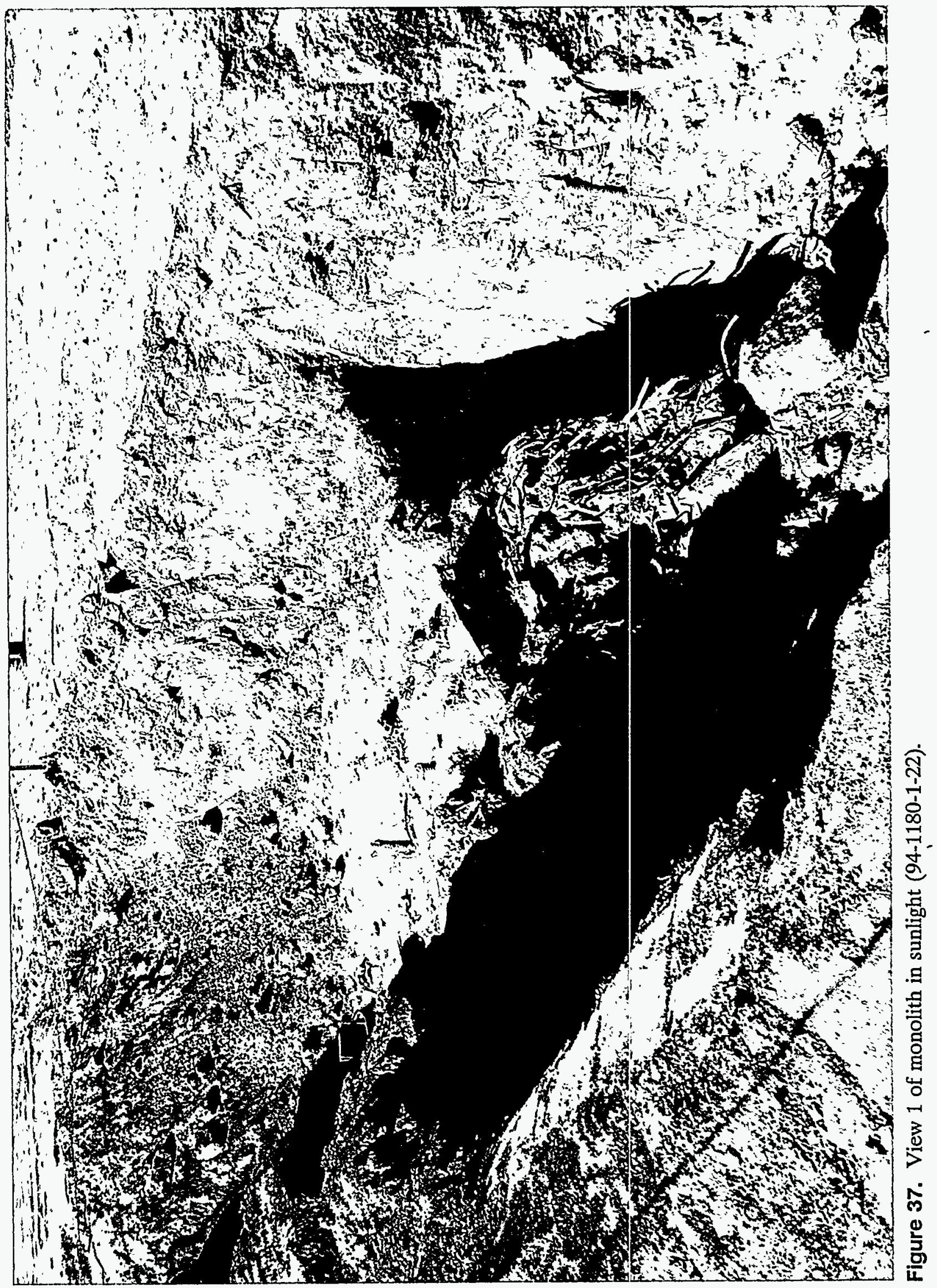





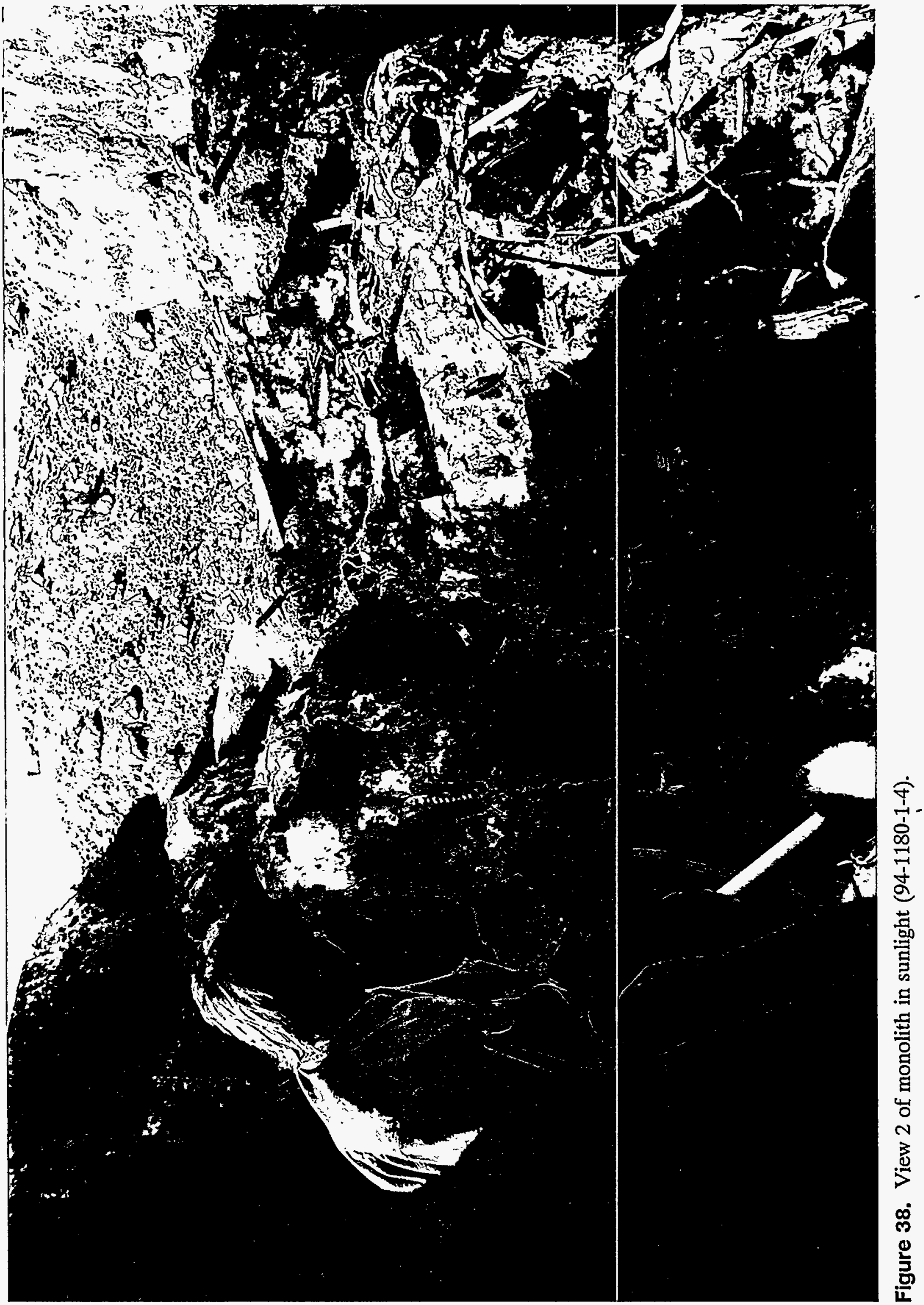



$--$ 


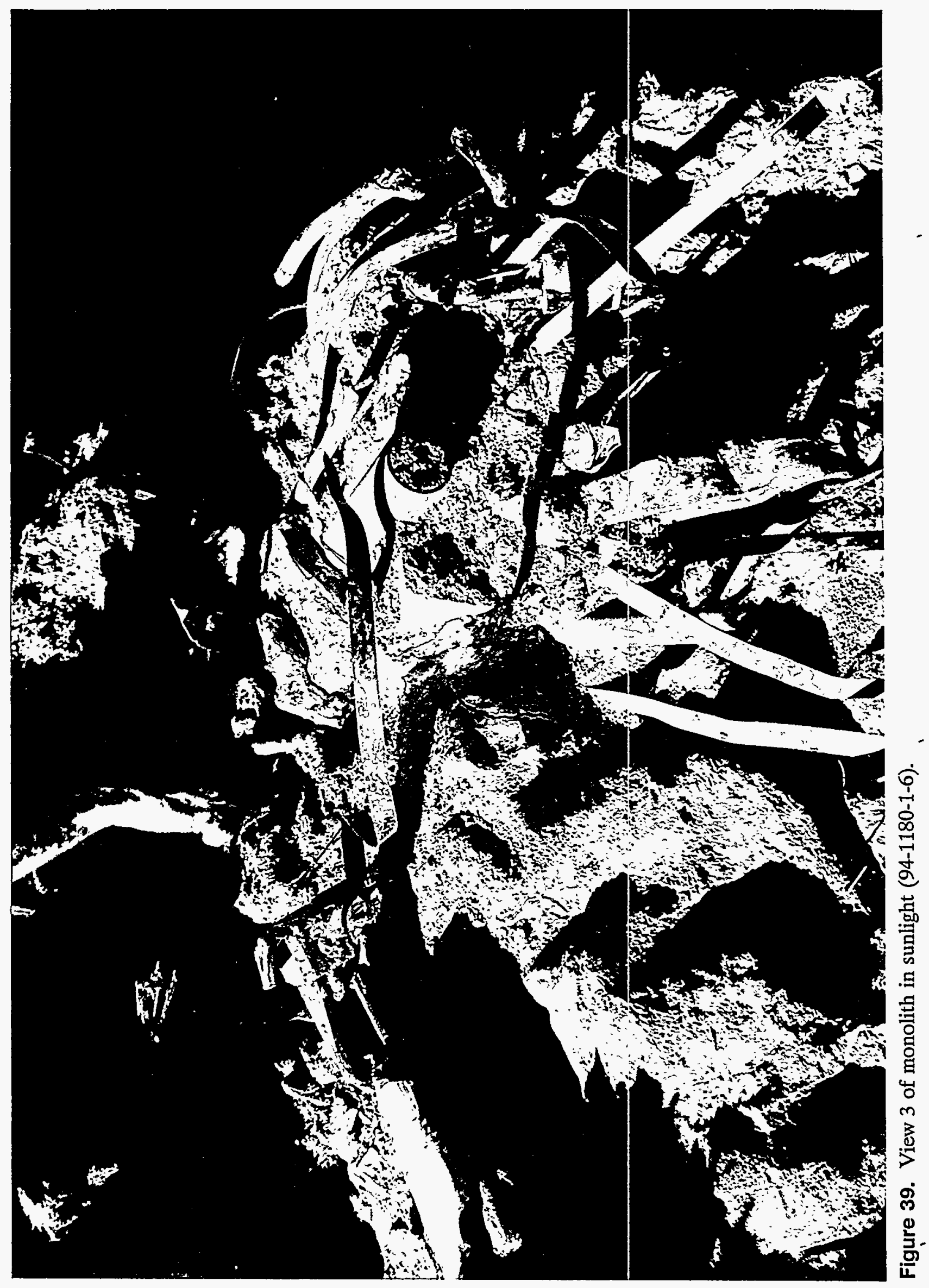





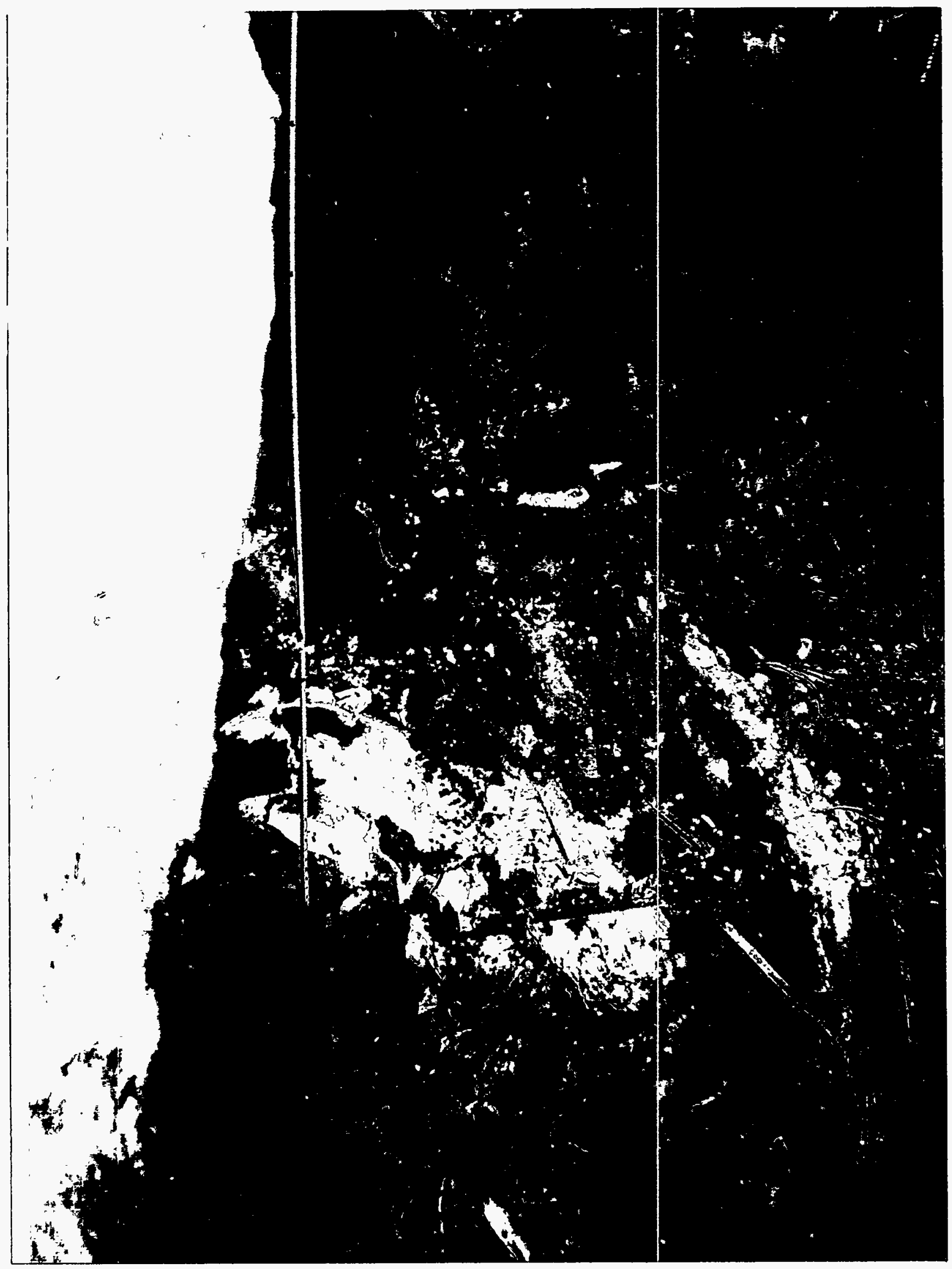

Figure 40. Rim of drum locked into grouted monolith (94-836-2-8). 



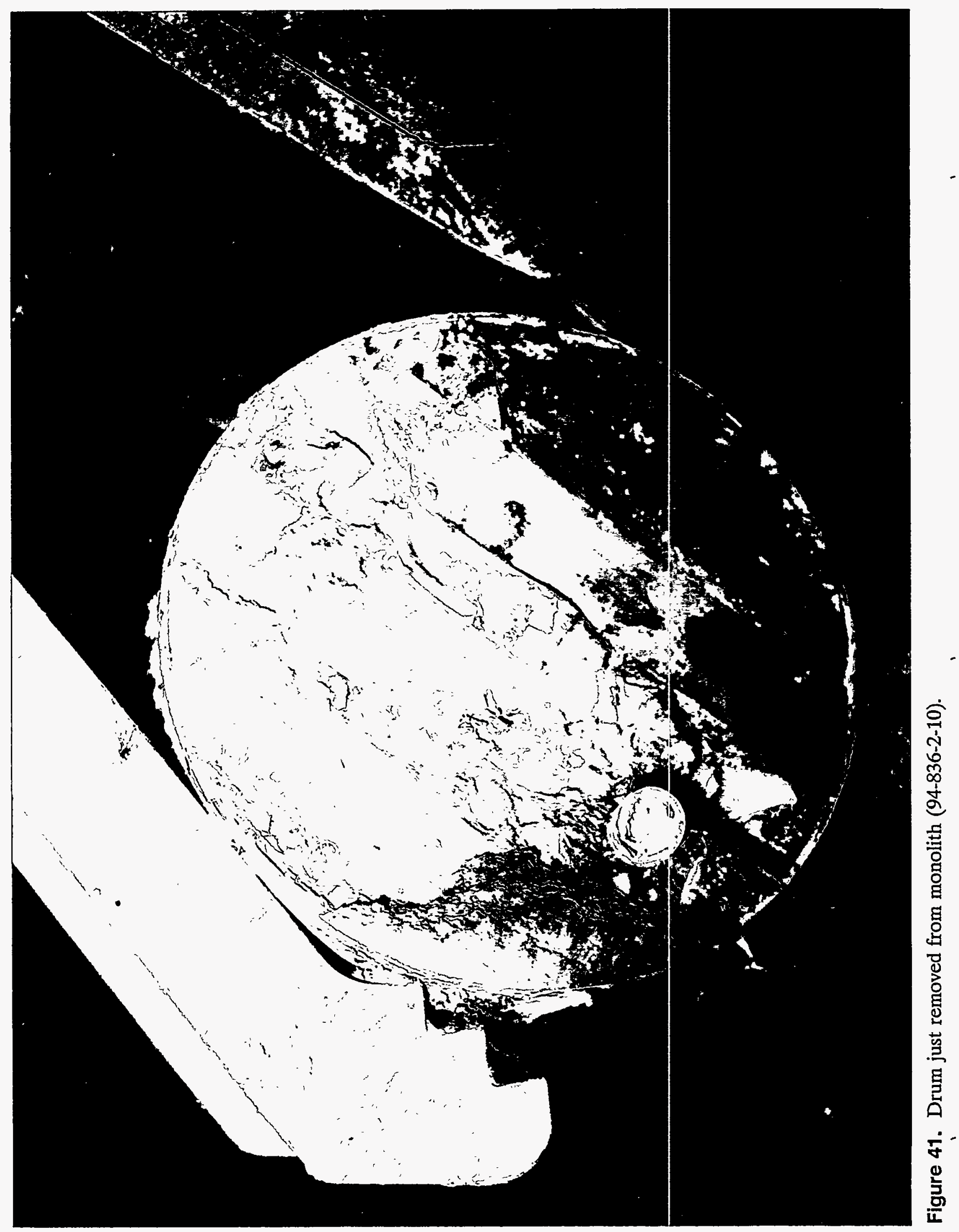





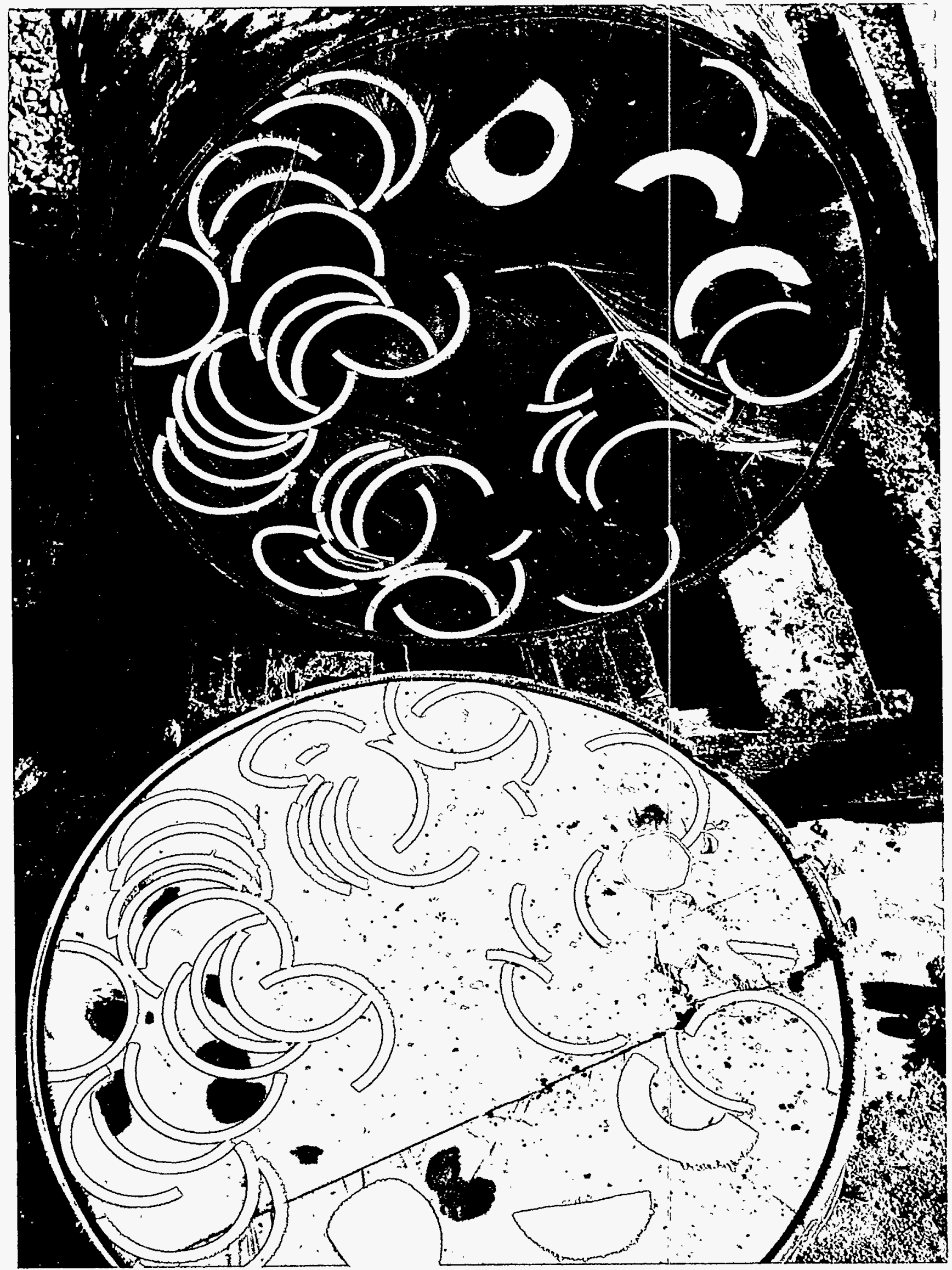

Figure 42. Gross sectional view of grouted drum (jet grouted 10-ft below surface) (94-913-2-28). 


\author{
.
}




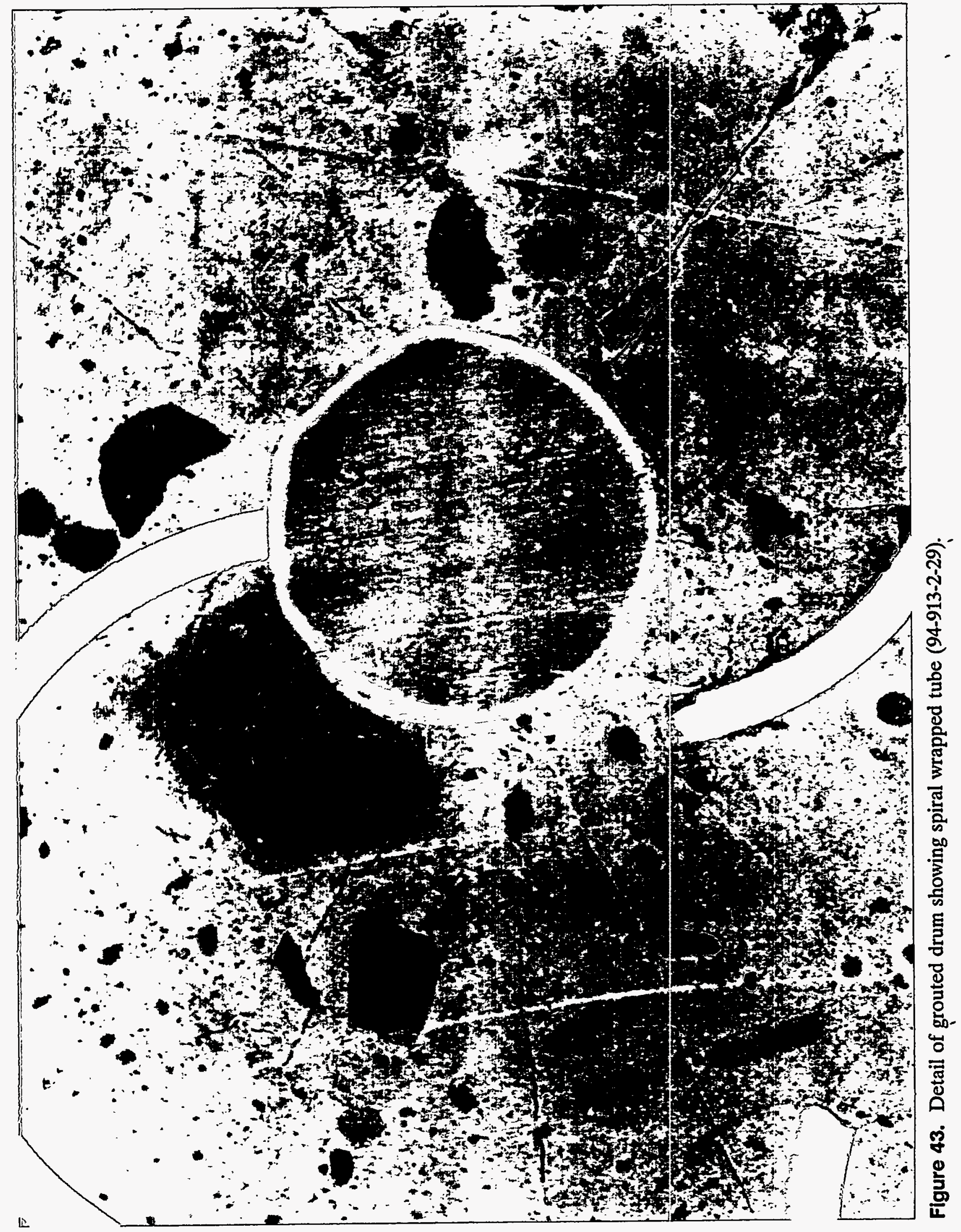





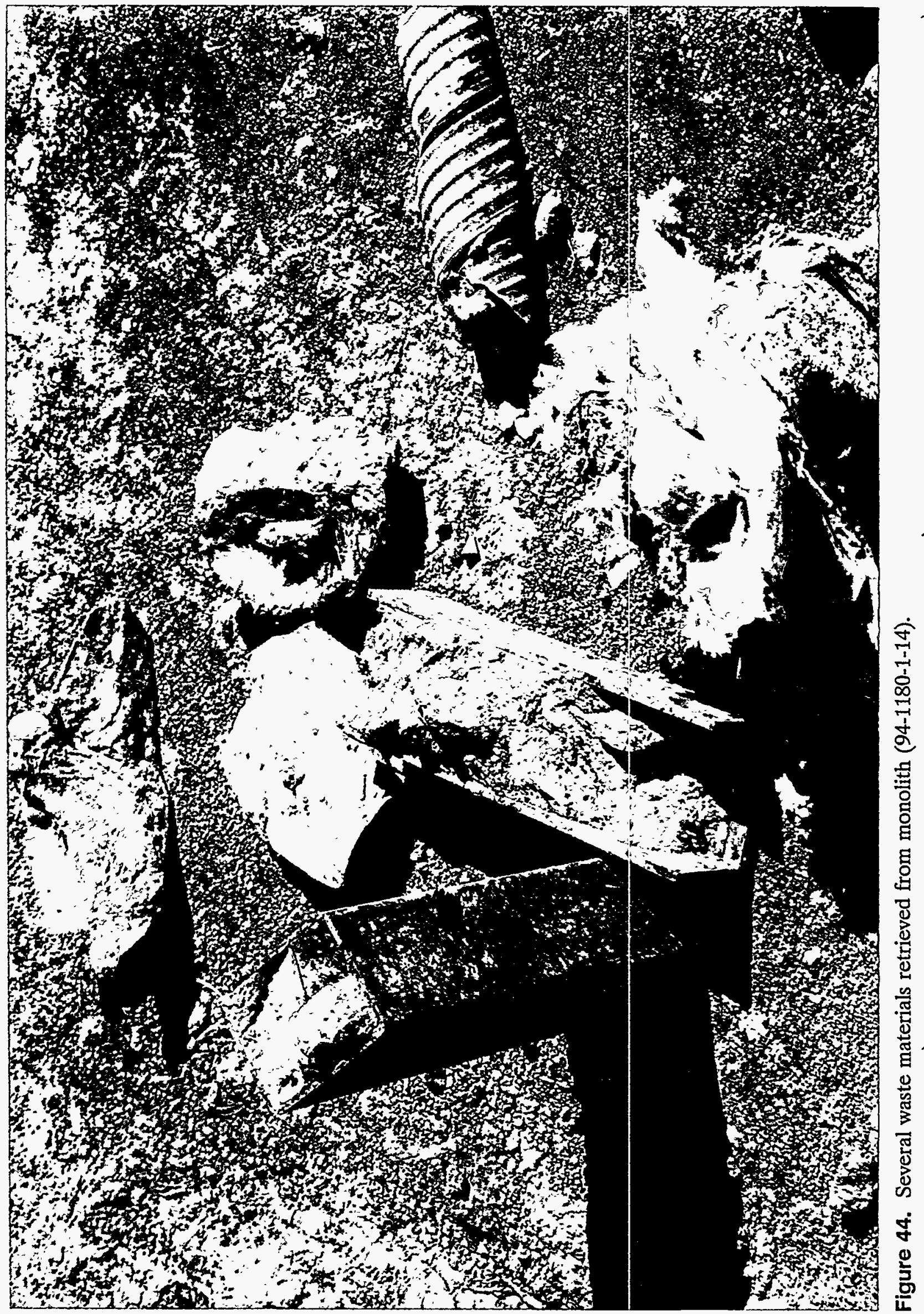




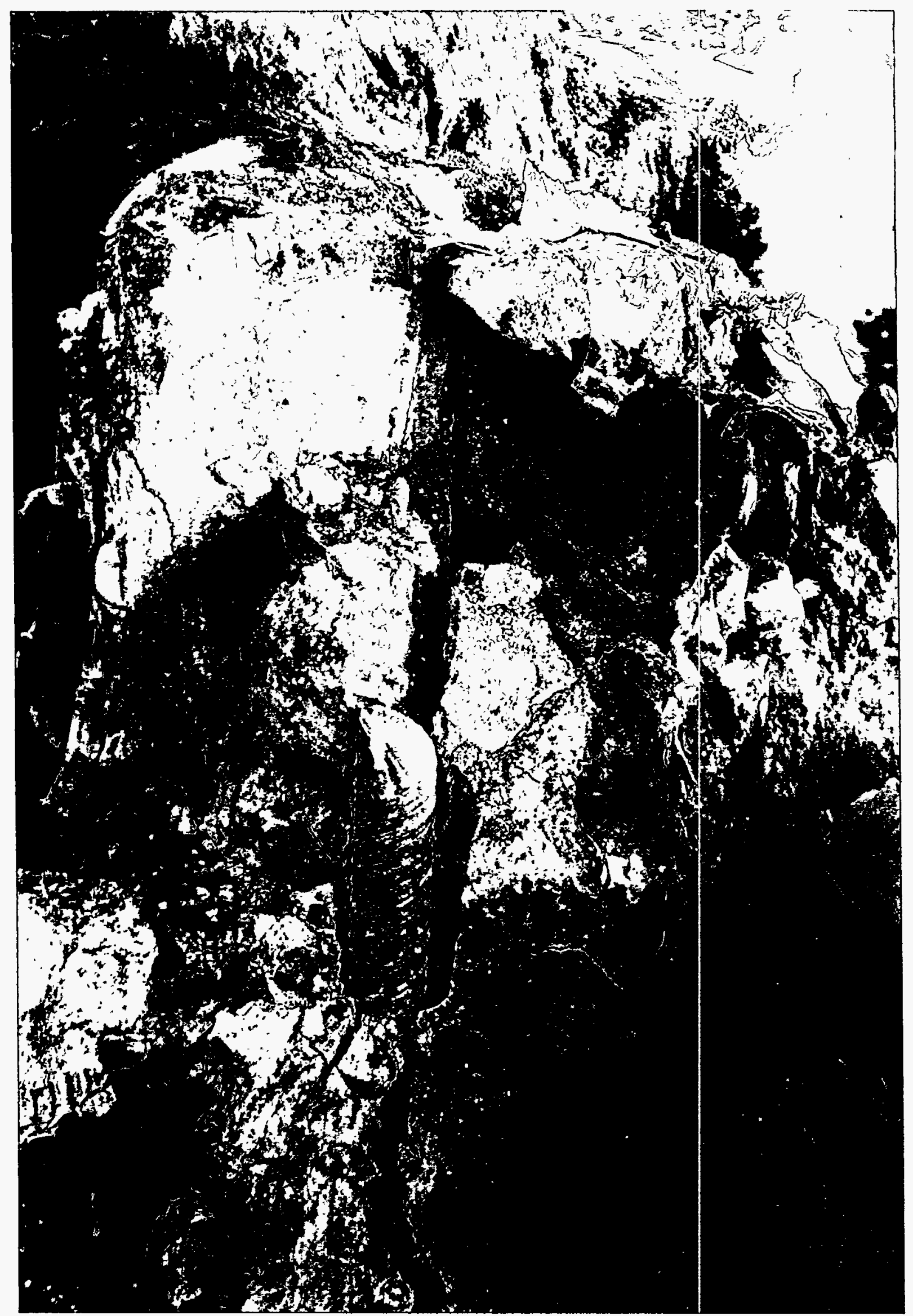

Figure 45. View 1 of fracturing of monolith with BRISTAR (special) (94-1180-1-2). 



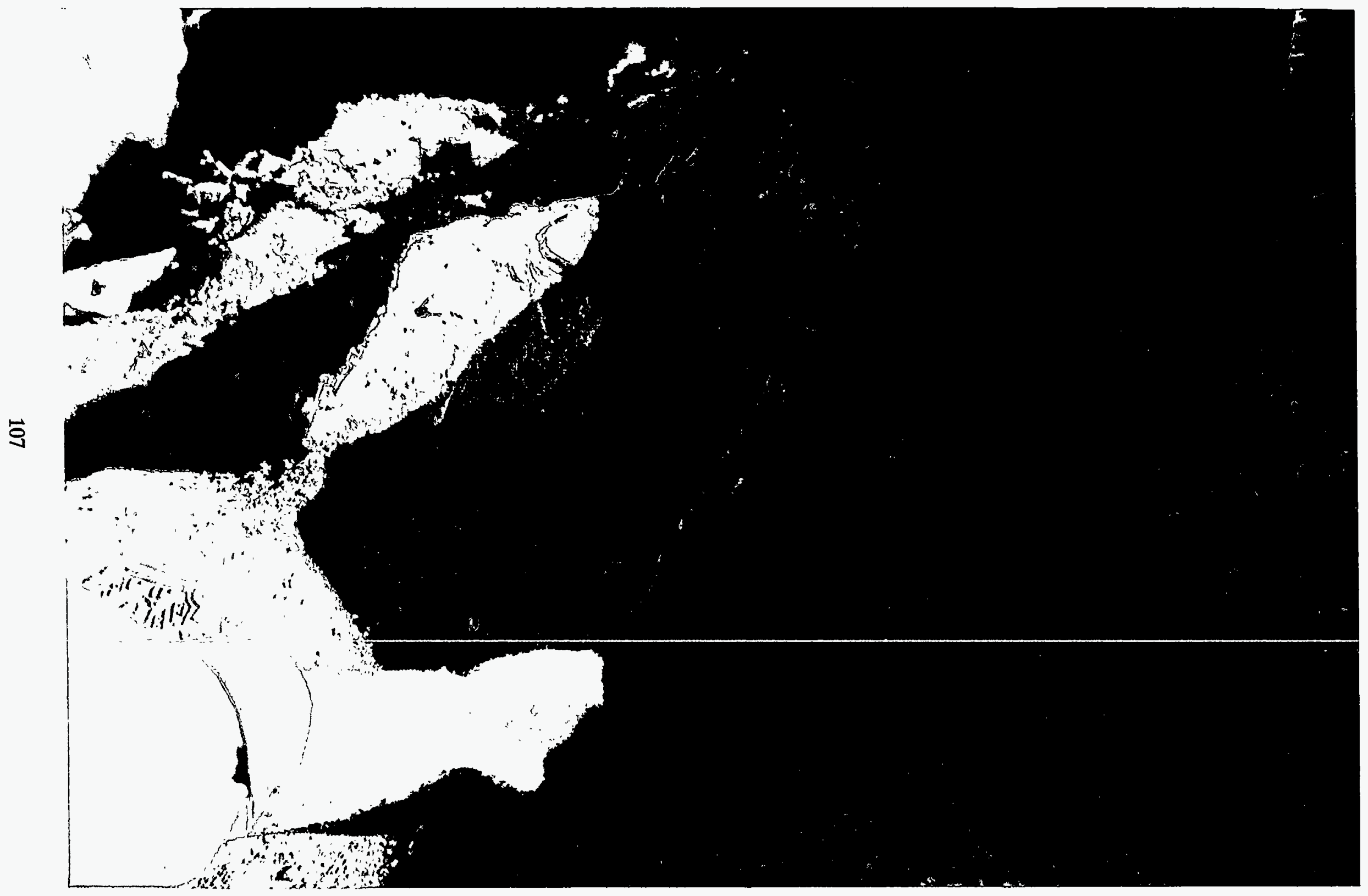

Figure 46. View 2 of fracturing of monolith with BRISTAR (special) (94-1180-1-9). 
Table 7. Average tracer and dust concentration data. ${ }^{a}$

\begin{tabular}{|c|c|c|c|c|c|c|c|c|c|c|}
\hline $\begin{array}{l}\text { Test } \\
\text { ID }\end{array}$ & $\begin{array}{l}\text { Net mass of } \\
\text { dust on filter } \\
\text { (g) }\end{array}$ & $\begin{array}{c}\text { Net } \mu \mathrm{g} \mathrm{Pr}^{\mathrm{b}} \\
\text { (total average } \\
\text { blank) }\end{array}$ & $\begin{array}{l}\mu \mathrm{g} / \mathrm{g} \mathrm{Pr} \\
\text { in dust }\end{array}$ & $\begin{array}{l}\text { Flow rate } \\
\text { (cfm) }\end{array}$ & $\begin{array}{c}\text { Tracer } \\
\text { concentration } \\
\text { ( } \mu \mathrm{g} / \mathrm{g} \mathrm{Pr} / \mathrm{cf}-\text { air })\end{array}$ & $\begin{array}{c}\text { Dust } \\
\text { concentration } \\
\text { (g/L-air) }\end{array}$ & $\begin{array}{c}\text { Tracer } \\
\text { concentration } \\
(\mu \mathrm{g} / \mathrm{g} \mathrm{Pr} / \mathrm{cf}- \\
\text { air) } \\
\text { background } \\
\text { corrected }\end{array}$ & $\begin{array}{l}\text { Standard } \\
\text { deviation } \\
\text { (2 sigma) } \\
\end{array}$ & $\begin{array}{c}\text { Dust } \\
\text { concentration } \\
\text { (g/L-air) } \\
\text { background } \\
\text { corrected }\end{array}$ & $\begin{array}{l}\text { Standard } \\
\text { deviation } \\
\text { (2 sigma) }\end{array}$ \\
\hline G-3 & 0.1043 & 0.7346 & 7.03 & 16.06 & $4.66 \mathrm{E}-03$ & 2.27E-07 & $1.63 E-03$ & $\pm 1.41 \mathrm{E}-03$ & $1.76 \mathrm{E}-07$ & $\pm 6.29 \mathrm{E}-08$ \\
\hline G-5 & 0.0995 & 1.2079 & 10.81 & 16.30 & $3.85 E-03$ & $1.30 \mathrm{E}-07$ & 8.23E-04 & $\pm 2.37 \mathrm{E}-03$ & 7.83E-08 & $\pm 4.47 \mathrm{E}-08$ \\
\hline G-7 & 0.2190 & 1.8392 & 8.34 & 15.21 & 2.27E-03 & $1.96 \mathrm{E}-07$ & $-7.59 E-04$ & $\pm 7.48 \mathrm{E}-04$ & $1.44 \mathrm{E}-07$ & $\pm 8.32 \mathrm{E}-08$ \\
\hline BKG & 0.0274 & 0.1947 & 6.16 & 17.06 & $3.02 \mathrm{E}-03$ & 5.13E-08 & $N A^{c}$ & $\pm 9.59 \mathrm{E}-04$ & NA & $\pm 2.28 \mathrm{E}-08$ \\
\hline BR-1 & 0.2359 & 2.5622 & 9.53 & 15.73 & $5.04 \mathrm{E}-03$ & $4.66 \mathrm{E}-07$ & 2.02E-03 & $\pm 6.95 \mathrm{E}-04$ & 4.15E-07 & $\pm 6.67 \mathrm{E}-08$ \\
\hline R-3 & 1.1014 & 170.50 & 1665.50 & 12.89 & $1.44 \mathrm{E}+00$ & 2.88E-07 & $1.44 \mathrm{E}+\infty 0$ & $\pm 6.29 \mathrm{E}-01$ & $2.36 \mathrm{E}-07$ & $\pm 8.75 \mathrm{E}-08$ \\
\hline R-4 & 0.0748 & 504.25 & 6358.38 & 13.55 & $8.11 E+00$ & 3.17E-07 & $8.11 \mathrm{E}+00$ & $\pm 6.38 \mathrm{E}+00$ & $2.66 \mathrm{E}-07$ & $\pm 1.37 \mathrm{E}-07$ \\
\hline R-5 & 0.2033 & 41.067 & 203.71 & 15.07 & $1.49 \mathrm{E}-01$ & 4.87E-07 & $1.46 \mathrm{E}-01$ & $\pm 6.11 \mathrm{E}-02$ & $4.36 \mathrm{E}-07$ & $\pm 8.50 \mathrm{E}-08$ \\
\hline $\mathrm{Br}-2$ & 0.6166 & 28.700 & 45.33 & 13.53 & 1.12E-01 & $4.99 \mathrm{E}-06$ & $1.09 \mathrm{E}-01$ & $\pm 3.35 \mathrm{E}-02$ & $4.94 \mathrm{E}-06$ & $\pm 7.42 \mathrm{E}-07$ \\
\hline \multicolumn{11}{|c|}{ a. Based on data for all samples shown in Appendix C. } \\
\hline \multicolumn{5}{|c|}{ b. Praseodymium. } & \multirow{2}{*}{\multicolumn{6}{|c|}{$\cdot$}} \\
\hline c. No & plicable. & & & & & & & & & \\
\hline
\end{tabular}


3.02E-03 ppm/ $\mathrm{ft}^{3}$ of air. This background dust concentration allows connecting data for the ambient amount of dust and tracer. In addition, the background gives an average concentration of tracer for establishing the spread of tracer during the various operations. The average concentration for praseodymium on the filter without considering the air flow was $6 \mathrm{ppm}$, which is comparable to the literature of expected soil concentrations in INEL soils.

\subsubsection{Grouting Activities}

During the grouting activities, the tracer spread was at background values within 2-sigma. In addition, the dust loading, on average, was only about a factor of 2 above background values. There were seven sets of dust and tracer concentration data taken during the grouting phases corresponding to time periods where the contents of the cement truck were set grouted into the pit. These testing periods were labeled G-1 through G-7. Several of the data sets were not evaluated for rare earth tracer because of operational difficulties with the samplers or weather changes outside of the large tent (such as wind storms) that invalidated the data. The data were valid for tests G-3, G-5, and G-7. Taken as an average of the three valid tests, the concentration of praseodymium was $3.59 \mathrm{E}-03 \mathrm{ppm} / \mathrm{cf}$, which compares to the background value of $3.02 \mathrm{E}-03 \mathrm{ppm} / \mathrm{ft}^{3}$ with $95 \%$ confidence. However, when examined alone, test G-7 had lower than background concentrations, and test G-3 had higher than background concentrations with G-5 at about background levels. The data log shows that during G-3, there was a large gust of wind at the entrance to the tent that added to the general dust loading and potential tracer spread; however, the measured airborne tracer amounts are at or near background values. During test G-4, there was copious bubbling of sludge up hole 6 when grouting hole 7 as reported earlier; however, the samplers were nonfunctional for that test and praseodymium analysis was not possible. Test G-7, however, had a similar phenomena with the sludge coming to the top of the pit, but for that test, the tracer concentration was lower than background. Overall, evidence of tracer movement in airborne samples was virtually nonexistent during the grouting phase. Airborne tracer was at or below background values within $95 \%$ confidence ( 2 standard deviations).

There was little variation in tracer concentration from sampler to sampler during the grouting phase (also shown in the detailed tables in Appendix C). Table 8 presents the results of analysis of some surface smears and sludge-like material that emanated from hole 6 during injection of hole 7. For the drill stem smears, the praseodymium concentration is at reported backgrounds with values from 3 to $5 \mathrm{ppm}$ nominally; however, the sludge material and other surface materials are much higher than background. For instance, the sludge in hole 6 had a concentration of praseodymium of $221 \mathrm{ppm}$, or 30 to 40 times background. Even with this large source of praseodymium in the tent, the airborne concentration was near background indicating that the sludge was locked in a grouted matrix and was not aerosolizable. Examining the dust loading during the grouting phase and comparing it to the background shows that average background values were 5.13E-8 $\mathrm{g} / \mathrm{L}$ and the average of the three grout tests G-3, G-5, and G-7 was $1.29 \mathrm{E}-7 \mathrm{~g} / \mathrm{L}$. This means that the activity associated with the grouting phase movement of the CASA GRANDE drill, personnel in and out to observe the grouted holes, and changeout of the filters only raised the dust loading by a factor of 4 .

\subsubsection{Retrieval}

Analysis of the dust and tracer movement during the retrieval phase had mixed results depending upon soil dryness and the lack or presence of overburden soils. Reductions in dust spread 
Table 8. Cement-soil type and smear samples for praseodymium by ICP-MS.

\begin{tabular}{|c|c|c|c|}
\hline $\begin{array}{l}\text { Sample } \\
\text { number }\end{array}$ & \multicolumn{2}{|c|}{ Sample description } & $\begin{array}{l}{ }^{141} \mathrm{Pr} . \mathrm{g} / \mathrm{g} \\
(\mathrm{ppm})\end{array}$ \\
\hline 1 & \multicolumn{2}{|c|}{ G-3 surface grout } & 3.68 \\
\hline 2 & \multicolumn{2}{|c|}{ G-3-2 surface grout (2nd) } & 3.76 \\
\hline 3 & \multicolumn{2}{|c|}{ G-4 hole 6-post hole 7} & 221 \\
\hline 4 & \multicolumn{2}{|c|}{ G-6 surface grout 17} & 39.9 \\
\hline 5 & \multicolumn{2}{|l|}{ G-6-18 } & 4.55 \\
\hline 6 & \multicolumn{2}{|c|}{ G-7-23 surface grout } & 38.6 \\
\hline 7 & \multicolumn{2}{|c|}{ G-7-24 surface grout } & 9.39 \\
\hline 8 & \multicolumn{2}{|c|}{ G-7-31 near surface } & 109 \\
\hline 9 & \multicolumn{2}{|l|}{ G-7-37 } & 4.82 \\
\hline 10 & \multicolumn{2}{|c|}{ Smear G-3-1 drill stem } & 5.01 \\
\hline 11 & \multicolumn{2}{|c|}{ Smear G-3-1 drill stem 2} & 3.24 \\
\hline 12 & \multicolumn{2}{|c|}{$\begin{array}{l}\text { Smear G-6 hole } 17 \text { drill } \\
\text { stem }\end{array}$} & 5.50 \\
\hline 13 & \multicolumn{2}{|c|}{ Duplicate G-7-37 } & 4.84 \\
\hline 14 & \multicolumn{2}{|c|}{ Matrix spike G-3-2 } & 10.7 \\
\hline 15 & \multicolumn{2}{|c|}{ Matrix spike 2 G-3-2 } & 12.1 \\
\hline \multicolumn{4}{|c|}{ Precision for Duplicates } \\
\hline \multicolumn{3}{|c|}{$\%$ Relative Percent Difference $=\quad 0.35 \%$} & \\
\hline \multicolumn{4}{|c|}{ Recovery of Matrix Spikes } \\
\hline \multicolumn{2}{|c|}{ Sample $1=$} & $106.1 \%$ & \\
\hline \multicolumn{2}{|c|}{ Sample $2=$} & $130.3 \%$ & \\
\hline
\end{tabular}

using the grouting technique compared to simply digging in soil varied between 36 and $91 \%$ depending on overburden orientation. For the tracer spread, there was a factor of 1.35 to 4,000 increase in measured tracer over the background value depending upon the lack or presence of overburden soils.

Two retrieval actions occurred as described in a preceding section: one with the overburden included (R-3, R-4) and one without overburden R-5. The retrieval was divided into two different actions because the overburden soils represented a considerable source of dust spread. It was thought that there would be an enhanced contamination control to perform the retrieval of the 
monolith with the overburden removed separately. Baseline retrieval actions in soil only were established separately for R-5 and R-3-R-4. This was accomplished because there was a major change in overburden configuration and soil dryness with the small tent (R-5) compared to the large tent (R-2 and R-4), and considerable tracer had been uncovered during retrievals $R-3$ and $R-4$ under the large tent. Table 9 summarizes airborne dust measurements, and Table 10 gives tracer spread data for runs R-3-R-4 and R-5. The discussion of the data on these tables is organized as to dust concentration data and tracer spread data.

4.5.3.1 Dust Concentration. The reduction in dust for the retrieval of the grouted pit compared to the baseline retrieval of soil only was higher for the data obtained under the small tent than for the large tent. The reduction in dust under the large tent was $43 \%$ for test $\mathrm{R}-3$ and $36 \%$ for test R-4. This compares unfavorably to values obtained during previous demonstrations where a $70 \%$ reduction in dust using water sprays, dust suppressants, and fixants ${ }^{8}$ was achieved. However, when comparing the baseline retrieval 2 data and run R-5 (under the small tent), there was a 91\% reduction in dust spread. Table 9 summarizes the dust concentration data during retrieval and shows the reduction in dust spread when comparing the baselines for the small and large tent retrieval runs. Examination of the dust concentration for retrievals R-3, R-4, and R-5 on Table 9 shows general drying of the pit and surrounding soils that occurred in the course of the demonstration. The data taken under the large tent had lower dust concentrations with the overburden included (runs R-3 and R-4) than for run R-5, which was performed under the small tent. This occurred even though the monolith and surrounding soil had dried considerably under direct sunlight during the 2-week period between performing the runs R-3 and R-4 compared to R-5.

For the data cited in Reference 8 (performed in the summer of 1993 using a small remote backhoe on an ungrouted pit), the samplers were turned off when the fork lift entered the weathershield or tent to remove the debris. For the FY-94 innovative grout demonstration, considerable visible dust was observed when the fork lift entered the tent to remove the 13 boxes of debris during the retrieval operation and this vehicle traffic was a major source of dust generation. Conditions at the INEL during the subject demonstration were characterized as an extremely dry summer with virtually no significant rainfall in the month before performing the demonstration. This contrasts to the conditions associated with Reference 8 in which the weather was characterized as the wettest summer on record with inch quantities of rain falling on the pit area before erecting the tent.

During the subject demonstration, the dust concentration for the small tent case represents a much drier digging scenario than the large tent case. For the large tent case, the top layer of overburden had protected the regions surrounding the monolith and the monolith itself from direct sunlight and therefore evaporation. Once the tent was destroyed by the July 21 storm, the top over burden and all surrounding areas continued to dry out. Additionally, the overburden was removed 3 days before the small tent data (baseline retrieval 2 and R-5) were taken. The top surface of the monolith, side burdens, and debris in the access pit were considerably drier (compares Figures 36 and 37 before performing run R-5 and baseline retrieval 2. Figure 47 gives a schematic for the retrieval performed under the small tent. Even with the drier soil, the reduction is dust spread when comparing the baseline retrieval to the retrieval of the grouted pit was higher. 
Table 9. Summary of dust concentration during retrieval.

\begin{tabular}{llcc}
\hline \multicolumn{1}{c}{ Test } & \multicolumn{1}{c}{ Configuration } & $\begin{array}{c}\text { Dust concentration } \\
(\mathrm{g} / \mathrm{L})\end{array}$ & $\begin{array}{c}\text { Dust reduction } \\
{[1-\mathrm{R} / \mathrm{BR}]^{*} 100 \%}\end{array}$ \\
\hline Baseline retrieval 1 & Large tent (moist) & $4.15 \mathrm{E}-7$ & - \\
R-3 & Large tent (moist) & $2.36 \mathrm{E}-7$ & 46 \\
R-4 & Large tent (moist) & $2.65 \mathrm{E}-7$ & 36 \\
Baseline retrieval 2 & Small tent (dry) & $4.94 \mathrm{E}-6$ & - \\
R-5 & Small tent (dry) & $4.36 \mathrm{E}-7$ & 91 \\
1993 demonstration $^{8}$ & $\begin{array}{l}\text { No contamination } \\
\text { control unit }\end{array}$ & $4.14 \mathrm{E}-7$ & - \\
& (baseline) & & 60 \\
1993 demonstration $^{8}$ & With contamination & $1.65 \mathrm{E}-7$ & \\
& control unit & & \\
\hline
\end{tabular}

Table 10. Summary of tracer spread during retrieval.

\begin{tabular}{|c|c|c|c|}
\hline Test & Configuration & $\begin{array}{l}\text { Tracer concentration } \\
\mathrm{ppm} / \mathrm{ft}^{3} \text {-air }\end{array}$ & $\begin{array}{c}\text { Ratio of tracer concentration } \\
\text { during retrieval and baseline } \\
\text { retrieval } \\
\text { (R/BR) }\end{array}$ \\
\hline $\begin{array}{l}\text { Baseline retrieval } 1 \\
\text { large tent (moist) }\end{array}$ & Large tent (moist) & 0.00201 & - \\
\hline R-3 & Large tent (moist) & 1.44 & $7.16^{\mathrm{b}}$ \\
\hline $\mathrm{R}-4$ & Large tent (moist) & 8.11 & $4034^{b}$ \\
\hline R-5 & Small tent & 0.146 & $1.35^{\mathrm{c}}$ \\
\hline Baseline retrieval 2 & Small tent & 0.108 & - \\
\hline \multicolumn{4}{|c|}{ a. Data corrected for background $\left(0.00302 \mathrm{ppm} / \mathrm{ft}^{3}\right.$-air $)$. } \\
\hline \multicolumn{4}{|c|}{ b. Used baseline retrieval 1 for ratio. } \\
\hline
\end{tabular}




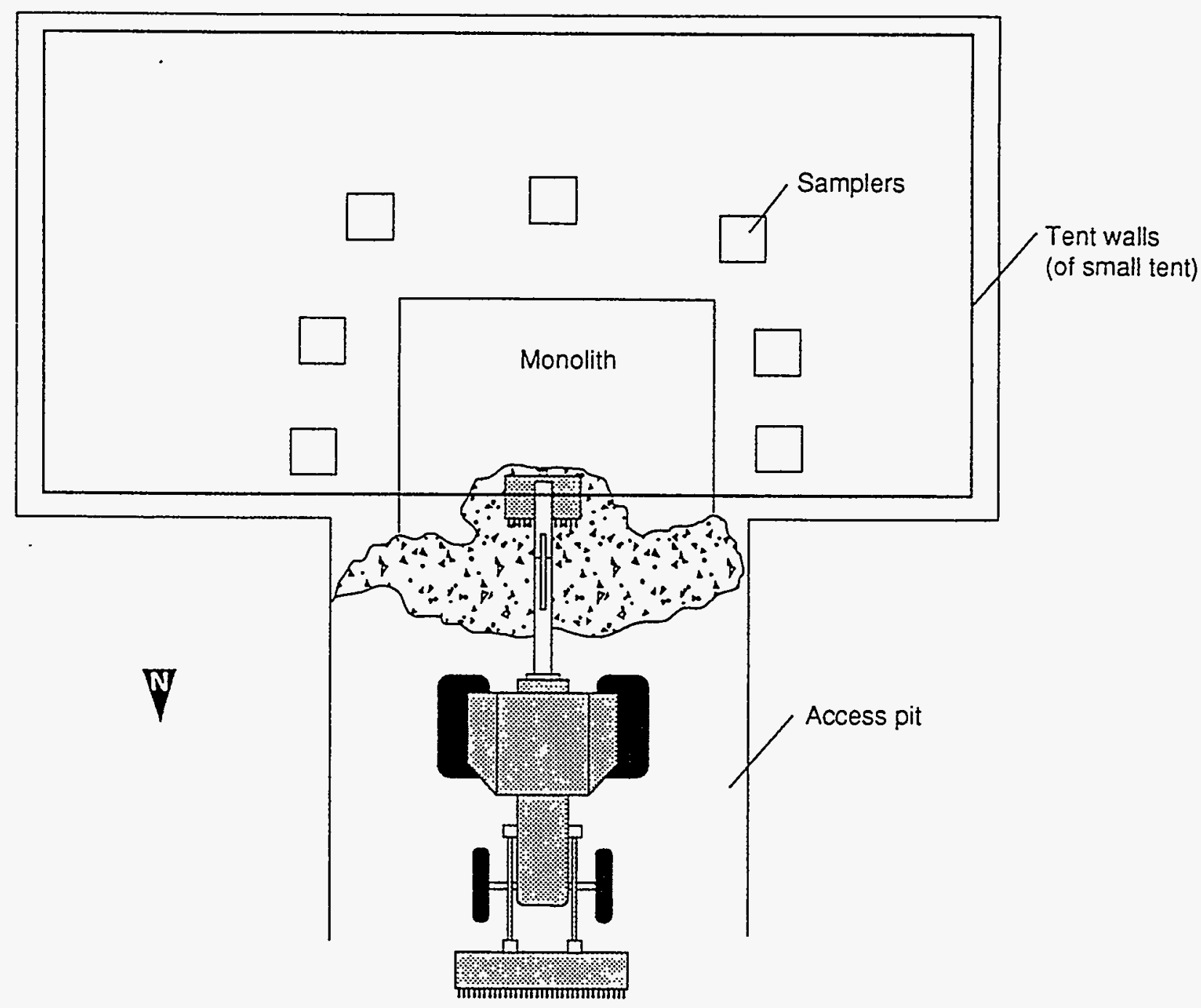

$\times 940438$

Figure 47. Orientation of "small tent" for final retrieval (R-5).

4.5.3.2 Tracer Spread. Tracer spread during retrieval activities involving simultaneous overburden removal was extensive; however, when the overburden was removed before retrieval, the spread of tracer was negligible. Table 10 compares the tracer concentration, background retrievals, and retrieval runs R-3, R-4, R-5. For R-3, the average tracer concentration was $1.44 \mathrm{ppm} / \mathrm{cf}$, and for $R-4$, the tracer concentration was $8.11 \mathrm{ppm} / \mathrm{cf}$. These values are 716 and 4,034 times the tracer concentration during baseline retrieval 1 indicating a large spread of tracer to the air filters. When the overburden was removed before retrieval, there was a drastic reduction in tracer spread compared to the baseline retrieval as shown on Table 10. The overburden was removed for the run R-5 and the tracer spread was negligible ( a factor of 1.35 times the baseline retrieval 2). The large tracer spread observed for R-3 and R-4 is due to the overburden soils falling into the pit containing flakes of soilcrete, soilcrete encrusted drums, and torn cardboard containers with computer paper. While the drums containing computer paper were generally encased in soilcrete, upon retrieval the backhoe operation tore the drums into several pieces and the cohesiveness of the grout to the paper was incomplete thus releasing the computer paper. There was visible praseodymium oxide powder on the paper for this case as shown in Figure 35. The overburden soil from further operations would fall 
through approximately $10 \mathrm{ft}$ to the bottom of the access pit and strike the computer paper, which was dry and unaffected by the grouting operation. The impact caused a displacement of air and drier soil/tracer mix was entrained upward in the resulting upward air flow and tracer was collected on the filters. Interestingly enough, computer paper also came out of the digface unaffected during the Cryogenic Retrieval Demonstration; ${ }^{5}$ however, during that demonstration, there was only 1/40 the amount of rare earth tracer in each container and the spread to samplers was not above background. This large reduction in tracer spread between R-3, R-4, and R-5 occurred even though the general moisture content of the pit had been greatly reduced by the drying from the sun. Another contributing factor to a much less tracer spread for the R-5 retrieval compared to the R-3 and R-4 retrievals was that a different digging technique was used. For R-5, the backhoe operator used slow deliberate movements and slowly peeled material off the monolithic block. For runs R-4 and R-5, a different operator used a violent pounding action with the end of the bucket. In addition, when dumping the waste into the waste transfer boxes for R-3 and R-4, multiple times the backhoe bucket struck the box when swinging from the pit and actually missed the dump causing debris to fall to the floor around the box. When digging, the same operator would allow the waste to accumulate in the access pit where overburden soil could fall on the waste and entrain soil and tracer upwards toward the samplers surrounding the monolith. The operator in the R-5 run; however, would clean the access pit out after only several bites on the digface resulting in less entrainment of tracer and soil. The operators only instructions were to remove the monolith, and their techniques represented different styles of digging. 


\section{LESSONS LEARNED}

The following itemized lessons were learned based on the various phases of the demonstration whether grouting, demolition grout, or retrieval.

\subsection{Grouting}

1. When grouting a pit, an alternating pattern of grouting should be used. The alternating pattern would involve spacing the grout holes in such a manner that in any one day no adjacent hole that is within 24 in. of each other would be grouted. This would ensure no ejection of grout or material from adjacent holes.

2. With a 4 to 5 -ft overburden on the pit, a spoils pit around the drill stem of up to $2 \mathrm{ft}$ deep and $2 \mathrm{ft}$ diameter could be made without the potential for blowout. This would preclude the need for run-off channels and a large spoils collection pit.

3. When applying grout, any indication of soilcrete returns up the drill stem containing waste material should result in an accelerated withdrawal rate until the waste material stops emanating from the drill hole.

4. When applying grout, the entire top surface of the pit should be treated with at least two coats of calcium lignosulfanate dust suppressant to reduce dust spread during operations.

5. A technique for early detection of a plugged injector should be developed.

6. Portland cement trucks should be cleaned of all sand before loading Portland to avoid pump and valve problems.

7. Portland cement should be mixed at the site of operation to avoid the potential of hydration on the long trip to the site.

8. When grouting the first hole, there may be a tendency to place multiple yards of grout in that hole (filling easily accessible voids in the bottom of the pit. This is desirable, but care must be given to not "float" the waste out of the pit by observing the surface of the pit for expansion. This phenomenon was not observed in the subject demonstration but has the potential to occur if grout is pumped into the pit unchecked.

9. If a large spoils pit is used, the spoils should be allowed to cure open air and additional spoils allowed to layer on top rather than placing soil on top of the spoils after completion of a grouting campaign. In this manner, waste will be minimized.

\subsection{Demolition Grout}

1. A longer period of time should be allowed to "cure" the pit before applying the BRISTAR demolition grout. This period of time may take up to 1 month before the large axial temperature gradient in the pit is reduced. 
2. Using bottom contact temperature measurements with a mercury bulb thermometer is not a good indication of the monolith temperature and the digital readout "hanging" thermocouple should be used in the spiral wrapped tubes.

3. A cost trade-off study or actual demonstration of the rock splitter concept should be made to provide the dust free demolition of waste.

\subsection{Retrieval}

1. Moisture control in the soils and soilcrete waste mix throughout the retrieval area is the key to contaminant control and tracer control. After 2 weeks in the sun, the dust loading for the baseline retrieval test (BR-2) was an order of magnitude higher than for the case under the large tent (BR-1).

2. A larger excavator system with a Balderson thumb attachment would have resulted in a less dusty retrieval operation. This excavator system should be operated abovegrade and the waste lifted in a backhoe motion. By using a large (235 CAT class) excavator, large boxes of grouted metal could have more easily been removed from the monolith block. In general, a larger excavator could remove larger intact portions of soilcrete causing resulting in less contaminated spread.

3. A large excavator could also have been utilized from belowgrade in a front shovel orientation. This would minimize the amount of debris falling into the pit causing tracer spread in entrained air flow.

4. The use of misting spray, fixants, and dust suppressants would have greatly reduced the spread of dust and tracer during the demonstration.

5. Fork lift traffic was a main source of visual dust spread during all of the retrievals under the large tent (R-1, R-2, R-3, and R-4). Any traffic under a weather shield or containment structure should be confined to prepared floors or "landing mats" to avoid this unnecessary dust spread. Surfaces on or near the pit should be sprayed with dust suppressant such as calcium lignosulfanate.

6. Dumping the waste into a box without the benefit of a funnel caused a great potential for tracer spread during R-1-R-4, as multiple times the backhoe material missed the center of the box when dumping and fell around the box.

7. The region in front of the tent became extremely dusty (i.e., "ankle deep") during the demonstration. This dust could enter the tent from the north during turbulent wind conditions associated with thunder showers. This area and all vehicle traffic areas around the tent should be treated with calcium lignosulfanate to avoid dust spread into and out of the tent. 


\subsection{General}

1. The tent specification should be more specific and should include 4-ft tie down anchors, lengthened side walls should be provided to avoid air flow under the tent, and nominal wind speed during erection should be expected to be $30 \mathrm{mph}$ with gusts to $45 \mathrm{mph}$.

2. Wind speeds to $85 \mathrm{mph}$ should be considered when procuring the tent.

3. Manometers should have been read every 10 minutes and logged to obtain a better average air monitor flow rate. Perhaps use of a data logger would be desirable for this operation especially if the overall operation is remote.

4. Better lighting in the tent would have improved the video and still photography performed in the tent. 


\section{FULL-SCALE APPLICATION}

To apply this technology to full-scale operations would require little change to the procedures used in the grouting phase; however, two outstanding questions remain relating to demolition grouting and retrieval of the monolith. The problem areas were stabilizing the axial temperature gradient in the monolith following grouting for application of the demolition grout and using the proper remotely controlled equipment to retrieve the waste. The following specific comments apply to the major areas of the technology including grouting, demolition grout, and retrieval.

\subsection{Grouting}

During the subject demonstration, there was no spread of tracer above background giving confiderice that the grouting activity could be accomplished in a hot environment without spread of transuranic contaminants. This confidence is especially high since the amount of tracer used in each container represents an unrealistically high amount of plutonium in each container. The subject demonstration used $200 \mathrm{~g}$ in each drum or box, which compares to the maximum gram quantities expected in each container in the INEL buried transuranic waste. The only outstanding issue that has not been addressed by the demonstration is the potential for explosion during the drilling of the grout holes. There is a remote possibility (not substantiated in the historical records) that there may be explosives or compressed gas cylinders in the pits and trenches. The consequences of the drill stem causing an explosion in such a scenario are unknown and should be investigated both analytically and experimentally. In any case, the drilling operation is completely suitable for remote operation as the control panel for the drilling rig is already $15 \mathrm{ft}$ away from the drill stem and removing the controls to a remote location is a minor engineering problem.

\subsection{Demolition Grout}

The demolition grout phase did not produce the fracturing that was expected due to improper use of the product. The product was introduced into the spiral wrapped tubes using ice water $\left(39^{\circ} \mathrm{F}\right)$, which is postulated to have reduced the temperature of the grout to a value where it would not expand. This unknown in the performance of demolition grout makes the evaluation incomplete. However, A-CORE, a concrete demolition company in Idaho Falls, Idaho, recommend the BRISTAR product if the temperature is correct for the product. Another idea from A-CORE is to use a rock splitter instead of the demolition grout as a cheaper alternative. This devise would go down the spiral wrapped tubes and hydraulically expand and split the monolith. This idea should be investigated.

\subsection{Retrieval}

The retrieval phase showed that a small standard backhoe could remove the monolith even in the unfractured condition. This operation could be greatly improved by using a large 235-CAT class excavator or larger. It would have facilitated the removal of the grouted box with metal. Although it would be recommended that a large remote excavator would be sufficient for full pit retrieval from either abovegrade or belowgrade, it would be difficult to retrieve the monolith in a hot spot scenario from a gantry crane due to the large torques developed. One possible method would be to use an "orange peel" grapple that drives points into the waste and lifts the waste vertically above the monolith with the gantry crane. An alternative idea and probably the most practical for either full 
pit retrieval or hot spot retrieval is to use the Mobile Retrieval Facility as proposed by Pacific Northwest Laboratories [contact: Gary Carter (509)-372-0670]. This facility is a mobile containment building that moves over the grouted pit and digs from a bridge crane superstructure.

\subsection{Cost Estimates}

The cost estimate for this technology is incomplete; however, a first order engineering estimate is summarized below assuming full pit retrieval and hot spot retrieval. These costs only reflect the costs of grouting, fracturing, and retrieval. Costs associated with buildings and conveyance equipment, packaging, assay, monitoring, contamination control, and disposal would be separately estimated based on risk assessment.

\subsubsection{Full Pit Retrieval (1-acre site)}

The estimate for full pit retrieval on a 1-acre site is

Grouting $-24,000$ holes at $\$ 250$ per hole $=\$ 6.0 \mathrm{M}$

Materials (Portland) $-24,000 \mathrm{yd}^{3}$ at $\$ 100 / \mathrm{yd}^{3}=\$ 2.4 \mathrm{M}$

Fracturing (BRISTAR) - 24,000 holes at $\$ 1,100$ per hole $=\$ 2.4 \mathrm{M}$

Retrieval (operations) $-3 /$ person crew at $200 \mathrm{yd}^{3}$ per day $=255$ labor-days

at $\$ 500$ per labor-day $=\$ 0.127 \mathrm{M}$

Retrieval (excavator-remote) - $\$ 1.5 \mathrm{M}$

Total: \$12.4M

\subsubsection{Hot Spot Retrieval}

This estimate is based on using the excavator in the full pit retrieval operation, grouting beyond the hot spot, and removing the interior hot spot to the grouted monolith. It assumes that the hot spot is $40 \times 60 \times 10 \mathrm{ft}$ deep and that the grouting would extend $10 \mathrm{ft}$ beyond the hot spot. It also assumes that there is only one hot spot to be dealt with:

Grouting $-1,968$ holes at $\$ 250$ per hole $=\$ 492 \mathrm{~K}$

Materials (Portland) - $\$ 648 \mathrm{~K}$

Fracturing - \$648K

Retrieval - same rates as full pit - $200 \mathrm{yd}$ /day on a $40 \times 60$ portion of the $50 \times 70$ grouted area $\$ 7 \mathrm{~K}$

Retrieval (remote excavator) - $\$ 1500 \mathrm{~K}$

Total: \$3295K

These costs could be doubled or tripled when considering the infrastructure (management), containment rather than weather shields, health physics support, and sampling required to perform the operation. 


\subsubsection{Alternative Hot Spot Retrieval}

This option compares favorably with the standard estimate of hot spot retrieval if the standard estimate is doubled for containment.

Grouting/fracturing same as above - \$2M

Retrieval using the Mobile Retrieval Facility from Pacific Northwest Laboratories

Facility - \$5M

Total: $\$ 7 \mathrm{M}$

This estimate involves building the mobile retrieval facility designed by Pacific Northwest Laboratories (contact: Gary Carter (509) 372-0670) and using this facility as the hot spot retrieval alternative with a jet grouted pit. 


\section{CONCLUSIONS AND RECOMMENDATIONS}

As an overall retrieval technology the idea of innovative grout/retrieval has potential application in buried waste sites where dust control is related to contamination control. The following specific conclusions and recommendations apply to the technology.

\subsection{Conclusions}

1. On an overall basis, a positive proof of concept has been shown for the innovative grout/retrieval technology in hot spot and full-scale retrieval for all major phases of the demonstration.

2. It is concluded that the grouting phase can be accomplished with a simple weather shield and still maintain control over contamination spread. This is based on the measured concentration of dust and rare earth oxide tracer spread during the grouting operation. The airborne tracer spread was measured at background values although waste material in the form of a slurry was present in spoils pits around the drill stem. The simulated contaminants (rare earth tracers) in the "ejected" material was locked up in a slurry mix and did not spread to surrounding regions. It is recommended, however, that the issue of explosion from striking buried pressurized bottles of gas would require a special safety analysis and cost/risk benefit analysis to determine whether the operation of drilling would require remote control. Remote control is possible with the CASA GRANDE drilling system.

3. It is concluded that the jet grouting technique created a monolithic block of waste/soil/Portland cement. Although there were small pockets of soil within the block, there were no continuous regions of soil that would be conducive to water migration through the block. There was no evidence of shadows using the nominal 24-in. hole spacing, and all waste material had been encapsulated with the soilcrete mix. Additionally, there was no volume increase in the pit from the jet grouting activity. There was a mass increase as $24 \mathrm{yd}^{3}$ of Portland cement was injected into the pit accessing about $60 \%$ voids.

4. It is concluded that the BRISTAR demolition grout causes extensive fracturing of the monolith if the temperature of the monolith is uniform and the correct product is applied.

5. For excavations involving side or "digface" retrieval, it is concluded that retrieval of the grouted monolith be accomplished only following overburden removal and before retrieving the monolithic block. Overburden tends to fall into the access pit and cause entrained air to carry contaminants throughout the retrieval area. Comparison of tracer spread with and without overburden removal shows a factor of 4,000 times background of air samplers with overburden and a factor of 1.35 times background without overburden. Application of misting systems for additional contamination control would eliminate any tracer or dust spread.

6. It is concluded that this technique would be ideally suited to retrieving regions of contaminated soil in a dust free manner. The tracer spread that was observed during the 
retrieval phase was caused primarily by grouted debris that "fell apart" during the excavation and dumping phase. A good example of this is the computer paper that did not mix with the jet grouting material. Instead, the computer paper was encased in the grout, which disintegrated upon retrieval.

7. It is concluded that for heterogeneous waste retrieval some water misting would benefit the inherent contamination control features of the grouted pit. This misting would help preclude the spread of tracers observed when the computer paper and cloth was removed from the monolith. By using both misting and the grout systems, the desired $98 \%$ removal of dust might be possible.

\subsection{Recommendations}

1. It is recommended that retrieval of the grouted monolith in the belowgrade (digface) mode utilize a large-scale remote excavator with dexterous Balderson thumb and a companion shear for removing metal debris. This same excavator could be used in the top down (backhoe) mode. For a hot spot retrieval application, it is recommended that an area larger than the "hot spot" be grouted to form a solid monolithic block followed by overburden removal and top-down large excavator retrieval. It is further recommended that this technique be tested in a cold test pit before "hot" application.

2. It is recommended that the temperature of the grouted monolith equilibrate with the surrounding soil before applying the demolition grout. Axial temperature gradients in the monolith make picking a grout type difficult. An alternative idea that requires demonstration is the use of a "rock splitter," which is a hydraulically operated expanding metal device that is inserted into the thin-walled spiral wrapped tubes.

3. It is recommended that a spoils pit be placed around the drill stem about $2 \mathrm{ft}$ deep and $2 \mathrm{ft}$ in diameter to collect spoils as small gallon quantities of soilcrete mix are ejected. An overburden of $4 \mathrm{ft}$ would be sufficient to accomplish grouting using this technique. 


\section{REFERENCES}

1. K. B. McKinley, "Initial Drum Retrieval Final Report," EG\&G Idaho, Inc., TREE-1286, August 1978.

2. J. B. Bishoff, "Early Waste Retrieval Final Report," TREE-1321, August, 1979.

3. G. G. Loomis and J. O. Low, Annual Technology Assessment and Progress Report for the Buried Transuranic Waste Studies Program at the INEL (1987), EG\&G Idaho, Inc., EGG-2525, January 1988.

4. G. G. Loomis and J. O. Low, "In-Situ Grouting for Improved Confinement of Buried TRU Waste at the INEL" Proceedings from SPECTRUM '88, Pasco Washington, September 11-15, 1988.

5. D. J. Valentich, et.al., Final Report for the Cryogenic Retrieval Demonstration, EG\&G Idaho, Inc., EGG-WTD-10397, September 1992.

6. P. G. Shaw, D. N. Thompson, and G. G. Loomis, Innovative Grouting/Retrieval Demonstration Test Plan, EG\&G Idaho, Inc., EGG-WTD-11350, June 1994.

7. L.C. Meyer et. al., La-Oxides as Tracers for PuO2 to Simulate Contaminated Aerosol Behavior, EG\&G Idaho, Inc., EGG-WTD-11161, April 1994.

8. D. N. Thompson, Evaluation of the Contamination Control Unit During Simulated Transuranic Waste Retrieval, EG\&G Idaho, Inc., EGG-WTD-10973, November 1993. 


\section{Appendix A}

\section{BRISTAR Grout Catalog}


A-2 


\section{Appendix A}

\section{BRISTAR Grout Catalog}

This appendix contains several pertinent features of the BRISTAR demolition grout and the effects of temperature on the various products. 


$$
\text { A-4 }
$$




\section{THE RIGHT GRADE, THE RIGHIT RESULTS}

A Iways start by matching the temperature of the material to be cracked with the temperature range of BRISTAR \& SUPER BRISTAR 2000. Also, match the temperature of the water with the grade of BRISTAR \& SUPER BRISTAR 2000 you are mixing.

\begin{tabular}{lccc} 
Item & Grade & $\begin{array}{c}\text { Temperature Of } \\
\text { The Material }\end{array}$ & $\begin{array}{c}\text { Temperature of } \\
\text { The Water }\end{array}$ \\
\hline SUPER BRISTAR 2000 & $\mathrm{H}$ & $77^{\circ}-95^{\circ} \mathrm{F}$ & below $77^{\circ} \mathrm{F}$ \\
\hline SUPER BRISTAR 2000 & $\mathrm{M}$ & $59^{\circ}-86^{\circ} \mathrm{F}$ & below $68^{\circ} \mathrm{F}$ \\
\hline SUPER BRISTAR 2000 & $\mathrm{L}$ & $41^{\circ}-59^{\circ} \mathrm{F}$ & below $59^{\circ} \mathrm{F}$ \\
\hline BRISTAR & 100 & $69^{\circ}-95^{\circ} \mathrm{F}$ & below $59^{\circ} \mathrm{F}$ \\
\hline BRISTAR & 150 & $50^{\circ}-68^{\circ} \mathrm{F}$ & below $59^{\circ} \mathrm{F}$ \\
\hline BRISTAR & 200 & $32^{\circ}-59^{\circ} \mathrm{F}$ & below $50^{\circ} \mathrm{F}$ \\
\hline
\end{tabular}

HOW TO

\begin{tabular}{l|c|c|c|c|c|c}
\hline & $\begin{array}{l}\text { Mixing } \\
\text { Water }\end{array}$ & $\begin{array}{c}\text { Mixing } \\
\text { Time }\end{array}$ & \multicolumn{1}{c|}{$\begin{array}{c}\text { How to } \\
\text { Mix }\end{array}$} & $\begin{array}{l}\text { Pouring } \\
\text { Time }\end{array}$ & \multicolumn{1}{c|}{$\begin{array}{c}\text { How to } \\
\text { Pour }\end{array}$} & $\begin{array}{c}\text { Cracking } \\
\text { Time }\end{array}$ \\
\hline $\begin{array}{l}\text { SUPER } \\
\text { BRISTAR }\end{array}$ & 1 liter & $20 \mathrm{sec}$. & $\begin{array}{l}\text { Add cool, clean water to a clean } \\
\text { Shallow pan. Mix in 1 bag of } \\
\text { SUPER BRISTAR 2000. Mix 1 } \\
\text { bag at a time. }\end{array}$ & $\begin{array}{l}\text { Within } \\
\text { 2 minutes }\end{array}$ & $\begin{array}{l}\text { Mixture is stiff. Move a rod up/ } \\
\text { down lightly while pouring and } \\
\text { remove gradually. Fill hole to } \\
\text { the brim. }\end{array}$ & $\begin{array}{c}40 \text { minutes } \\
-3 \text { hours }\end{array}$ \\
\hline BRISTAR & 1.5 liters & $\begin{array}{l}2-3 \\
\text { minutes }\end{array}$ & $\begin{array}{l}\text { Add cool, clean water to a } \\
\text { clean bucket. Mix in 1 bag of } \\
\text { BRISTAR. Several bags can be } \\
\text { mixed at a time. }\end{array}$ & $\begin{array}{l}\text { Within } \\
5 \text { minutes }\end{array}$ & $\begin{array}{l}\text { The slurry is easy to pour. Fill } \\
\text { hole to the brim. }\end{array}$ & $\begin{array}{c}10-20 \\
\text { hours }\end{array}$ \\
\hline
\end{tabular}

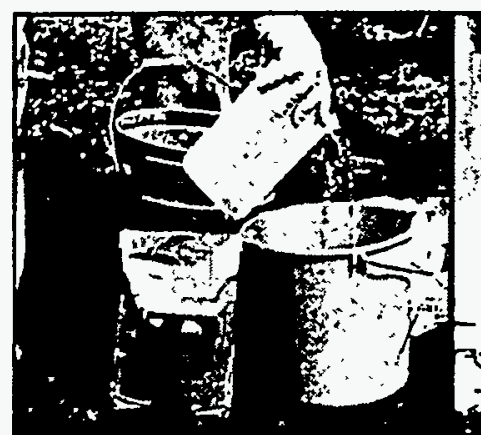

Pour pre-measured water into container.

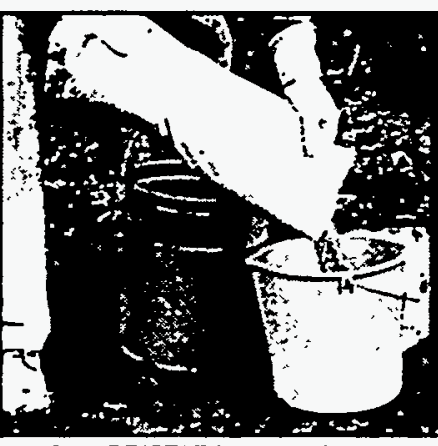

Pour BRISTAR into container.

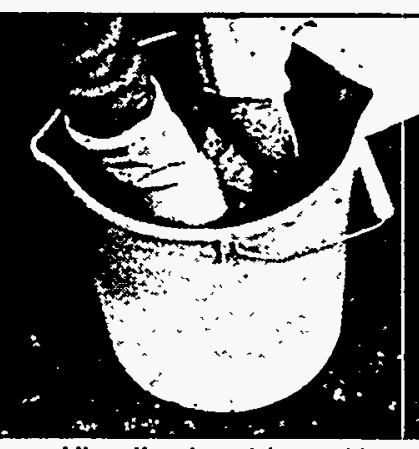

Mix uniformly and thoroughly.

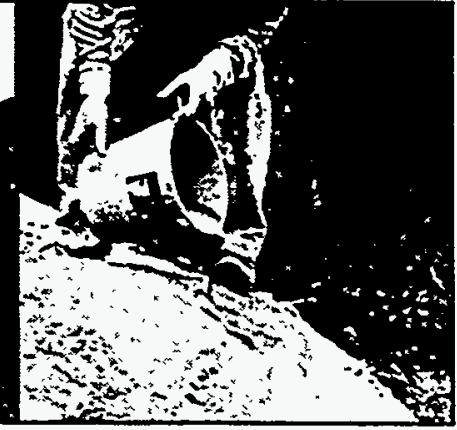

Pour into pre-drilled hole. HOW MUCH

D esigning hole patterns is an art we practice everyday. We will be happy to design yours. And once you've got a hole pattem, it's simple to figure out how much BRISTAR you need. The formula: LB/FT $\times$ Number of Holes $\times$ Depth of Holes $\div 44$ (lbs.).

\begin{tabular}{|c|c|c|c|c|c|c|}
\hline Hole Diameter & & $11 / 2^{n}$ & $15 / 8^{\prime \prime}$ & $13 / 4^{\prime \prime}$ & $17 / 8 "$ & $2^{n}$ \\
\hline SUPER & $(\mathrm{lb} / \mathrm{t})$ & no & 1.8 & 2 & 2.2 & no \\
\hline BRISTAR 2000 & (ft/bag) & no & 6.1 & 5.4 & 4.9 & no \\
\hline & $(\mathrm{lb} / \mathrm{ft})$ & 1.3 & 1.5 & 1.8 & 2. & 2.4 \\
\hline DHISIAN & (tt/bag) & 8.5 & 7.2 & 6.2 & 5.5 & 4.5 \\
\hline
\end{tabular}

Note: The chart shows how many drilled feet one $11 \mathrm{lb}$. bag of BRISTAR yields. There are four $11 \mathrm{lb}$. bags per case. You may get $3 \%$ to $6 \%$ less due to field conditions like spilling and actual hole size. 


\section{WHAT IS BRISTAR?}

BRISTAR is a soundless and safe demolition agent which is quite different from ordinary demolition agents such as explosives and dangerous materials. It dnes not cause any flyrock, noise. ground vibration. gas. dust or any other environmental pollution when used properly.

As requirements for demolishing rock and reinforced concrete in construction increase in tight quarters, the use of explosives and explosive agents is becoming more restricted as far as safety and environmental pollution problems are concerned. BRISTAR is the solution.

When BRISTAR is mixed with an appropriate quantity of waster and poured into cylindrical holes drilled in rock or concrete, it hardens and expands. BRISTAR cracks the matter to be demolished which then can be easily removed with a pick breaker, pneumatic breaker, excavator, etc.

There are currently 4 grades of BRISTAR on the market designed for various temperature ranges (shown in Fig. 1) of material to be cracked. Since a chemical reaction of BRISTAR depends on temperature, use the proper type of BRISTAR listed in Table 1.

Table I. BRISTAR designed for various range of temperature

\begin{tabular}{|c|c|c|}
\hline \multicolumn{2}{|c|}{ TEMPERATURE RANGES } \\
\hline Product & $\begin{array}{c}\text { Material Temp. } \\
\text { Range }\end{array}$ & $\begin{array}{c}\text { Mixing Water } \\
\text { Temp. }\end{array}$ \\
Bristar 100 & 69 to 95 F & $59^{\circ}$ \\
Bristar 150 & 50 to 68 F & $59^{\circ}$ \\
Bristar 200 & 32 to 59 F & $50^{\circ}$ \\
Bristar 300 & 23 to 41 F & $41^{\circ}$ \\
& & \\
\hline
\end{tabular}

B-100, and B-200 used in this brochure indicate BRISTAR 100, 150, 200, and 300 , respectively.

\section{ADVANTAGES OF BRISTAR}

I. BRISTAR IS A SAFE SUBSTANCE.

BRISTAR is not controlled by any legal regulation such as explosives and explosvie agents, etc. Qualified persons are not required for handling. Demolition can be easily and safely performed anywhere.

II. BRISTAR IS A SOUNDLESS CRACKNNG AGENT.

Unlike the existing methods of demolition, BRISTAR does not make any noise, vibration, flyrock, dust or gas. Rocks and reinforced concrete may be demolished safely without environmental pollution. Furthermore, BRISTAR'S expansive stress continues even after crack initiation, the crack opening distance becomes wider as time passes.

III. BRISTAR HANDLES EASILY.

No lid (or cap) is necessary after BRISTAR is poured into a hole of rock or reinforced concrete, nor is tamping required as with explosives. BRISTAR exerts jts strength in a short time. Due to BRISTAR'S strong adhesion and frictional resistance to inner surface of the hole, spurs due to heat-generation (blown-out shot) do not occur when used within the parameters as noted in the conditions. The expansive stress along the hole depth is almost constant except for that near the entrance of the hole. Generally the expansive stress loss from the hole entrance has litule effect on the demolition work when hole depth is long.
IV. BRISTAR HAS AN EXPANSIVE STRESS OF MORE THAN 6000

$t / \mathrm{m}^{2}$ (fig. $2,3,4$ )

Generally, the compressive fracture stress of rocks is 1000 to $2000 \mathrm{~kg} / \mathrm{cm}^{2}$ and that of concrete 1.50 to $500 \mathrm{~kg} / \mathrm{cm}^{2}$. However, the tensile fracture stress is very small. i.e., it ranges from $401070 \mathrm{~kg} / \mathrm{cm}^{2}$ in concrete, respectively. Since demolition by using BRISTAR is based on a fracture due to a tensile stress, all kinds of rocks and concrete can be cracked and broken by using BRISTAR when appropriate holes are properly drilled.

\section{PROPERTIES OF BRISTAR}

I. CHEMICAL COMPONENTS OF BRISTAR

BRISTAR is a powder consisting of an inorganic compound made mainly of a special kind of silicate and an organic compound. BRISTAR does not contain any harmful components.

II. SOME EFFECTS ON THE EXPANSIVE STRESS OF BRISTAR

1) The expansive stress increases more than $6.000 \mathrm{t} / \mathrm{m}^{2}$. (Fig. 1, 3, 4)

2) The larger the hole diameter is, the greater the expansive stress becomes. (Fig. 2)

3) There is little change in the expansive stress when the water ratio is in the neighbortood of approximately $30 \%$. However, the stress is decreased as the water ratio is increased or decreased.
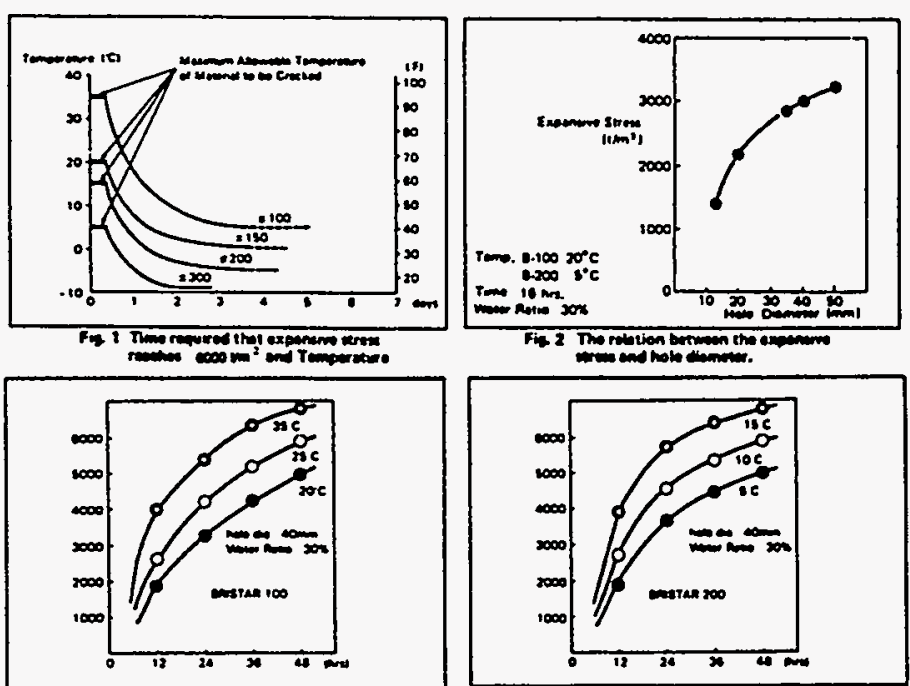

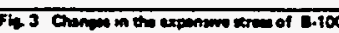
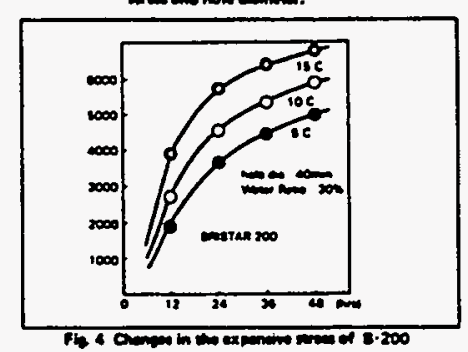

\section{FRACTURE MECHANISM}

After BRISTAR is poured into holes drilled in rocks or concrete, the expansive stress gradually increases with time, and reaches to more than $6000 \mathrm{Um}^{2}$ at room temperature after 24 hours. As the BRISTAR generates its expansive stress, the material to be cracked undergoes a process of (1) crack initiation, (2) crack propagation, (3) the increase of crack width. Therefore, this fracture mechanism is distinguished from a breakage by blasting.

The mechanism by the expansive stress of BRISTAR is shown in Fig. S. Cracks initiate from an inner surface of the hole, being caused by tensile stress at a right angle with the compressive stress which occurs by the expansive stress of BRISTAR. The expansive stress of BRISTAR continues even after the appearance of cracks, the cracks propagate and also new cracks initiate during the 
process, Usually, for a single hole, $2-4$ cracks initiate and propagate. When a free surface exists, the crack, as shown in Fig. 6, is pushed apart mainly by the shear stress, and a secondary crack also arises from the bottom of the hole running toward the free surface.

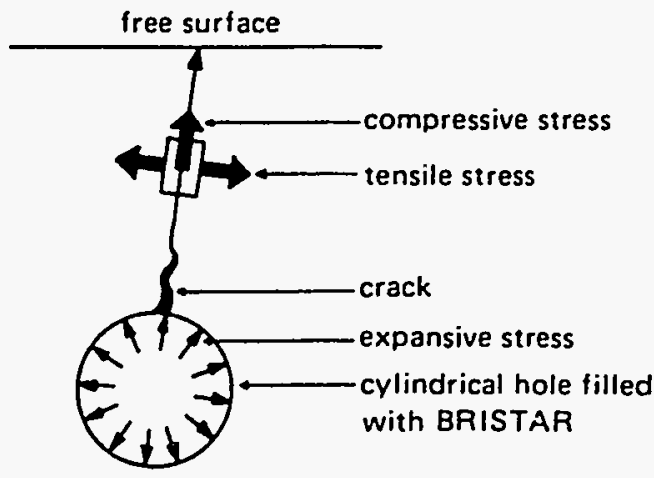

Fig. 5 Fracture mechanism by the expansive stress of BRISTAR

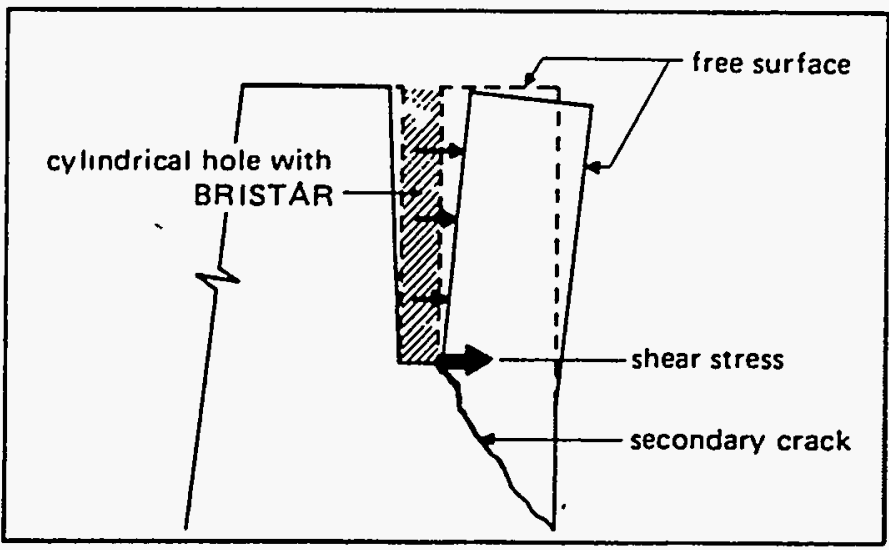

Fig. 6 Sectional-view of the crack formation in the material with two free surfaces

When multiple numbers of holes are filled with BRISTAR, that are properly adjacent to each other, the cracks from the hole propagate to connect with the neighboring holes, as shown in Fig. 7.

It is therefore possible to determine the directions of the cracks as planned by appropriately arranging the hole spacing and its depth and its inclination.

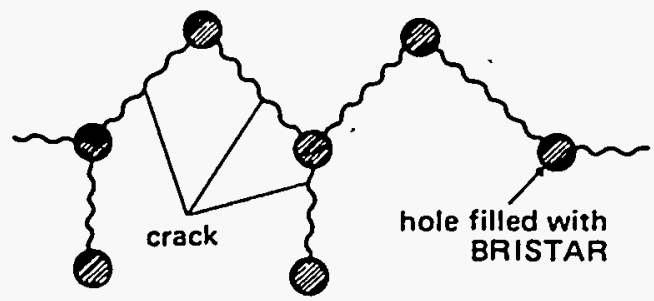

Fig. 7 Crack propagation

Establishment of free surface

In the case of trenching, shafting or turneling, if all boles are drilled vertically and filled with BRISTAR, the crack width can not increase but horizontal cracks initiate. Therefore, in order to obtain two free surfaces, inclinated holes or pre-splitting must be required. (Refer to APPENDIX)

\section{TEST BREAK AND DRILLING}

BRISTAR'S effectiveness, therefore, depends on the placement of the holes. The drilling must be done in relation to the job to be performed.

\subsection{Test design and breaking}

The design for breaking should be done according to the properties of rocks, joint. volume to be removed, secondary breaking, and work period, etc. Table IIl should be taken into account for the design.

Prior to the execution of test break, reference should be made to APPENDIX to assist in break design.

To determine which combination of hole size and spacing is most desirable, drill several holes of different diameter at different burden and spacing, check each of the break conditions and then decide hole diameler, depth. burden and spacing.

Table III Type of Breaking by BRISTAR

\begin{tabular}{|l|l|}
\hline \multicolumn{1}{|c|}{ Type } & \multicolumn{1}{c|}{ Secondary breaking } \\
\hline Fragmentation & $\begin{array}{l}\text { Hammer. Power shovel } \\
\text { Hand breaker, Power shovel. Hydraulic } \\
\text { breaker formation } \\
\text { Combination of mechanical breaker or } \\
\text { dynamite }\end{array}$ \\
\hline
\end{tabular}

\subsection{Drilling}

Drilling
machine:
II. Drilling
direction:

Use electrical drill, rock drill or crawler drill.

It is preferable to drill holes vertically, but in cases of a wall or pillar of reinforced concrete where vertical drilling is hard, an inclined hole may be drilled. Since a greater effect is achieved with a deeper hole, in case of a thin material, consideration should be given so as to get a long hole depth by drilling it obliquely if necessary. Horizontal holes can be applied the same idea of spacing as with vertical holes.

III. Hole Dia- The breaking plan of Table IV can serve as a meter and guidance in making a decision. In general, the hole preferable hole diameter is from $401050 \mathrm{~mm}$ spacing: $\quad(1 / 2 \times 2 \times 2 ")$

Table IV. Material and proper hole spacing

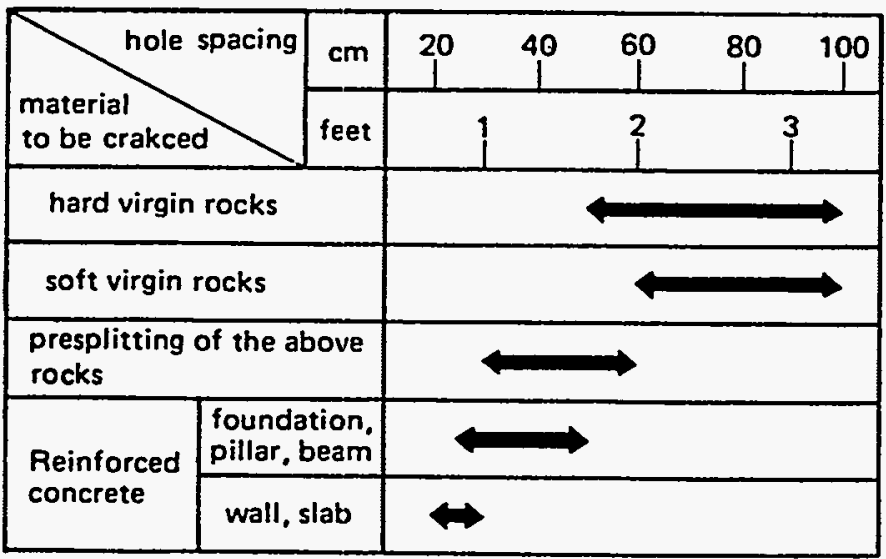


IV. Hole depth:

This varies with the shape of the material to be cracked or the break plan. Refer to APPENDIX as a guide line.

It should be noted that BRISTAR mixed with water can easily be applied by hand, when the hole depth is up to approximately 10 meters. When the depth is less than 3 times the diameter of the hole, less cracking will occur, the breaking effect is lessened and the time required for demolition is increased.

\section{- 5.3 Use of thin steel pipe}

In the case of a temporary concrete structure (to be demolished), place thin steel pipes (the thickness: $0.8 \mathrm{~mm}\left(1 / 32^{\prime \prime}\right)$ i.e. a sheath pipe for P.S. concrete) as holes before placing concrete instead of drilling. Whenever the structure needs to be cracked, fill BRISTAR in the pipes. There is no change in breaking effect by the use of pipe.

\section{MIXING AND FILLING}

6.1 Mixing of BRISTAR

I. Mixing Equipment:

Mix one bag ( $5 \mathrm{~kg}, 11 \mathrm{lb}$ ) of BRISTAR with water at a time by hand or preferably with a mechanical mixer. Prepare the following equipments.

(1) Container: For one bag of BRISTAR - a metal bucket or clean can of 10-20 liters capacity.

(2) Mixer: For instance, hand-mixer.

(3) Water meter: Breaker or measuring cylinder.

(4) Protector: Rubber gloves, safety goggles.

II. Mixing Method

Pour approximately 1.5 liter (0.4 U.S. gallon) of water into container. Add one bag of BRISTAR gradually and mix well until it has a good nuidity.

When a viscosity of the mixture of BRISTAR and water is too high to pour into the hole, add a little water to get a good fluidity. Do not exceed $34 \%$ of water ratio (1.7 liter; 0.45 U.S. gallon per $5 \mathrm{~kg}$ : 11 lb. of BRISTAR). The mixing time by hand-mixer is about 2.3 minutes (it is recommended that mechanical mixer be used on large volume jobs). When mixing by hands, wear rubber gloves.

III. Mixing Water

Refer to chart found on page one. Use clean water.

IV. Standard Quantity

The quantity of BRISTAR to be used for cracking differs with the hole spaces and diameters. In Table $V$, the relation between the quantity of BRISTAR used and the hole diameters is indicated for the hole of $1 \mathrm{~m}$ depth, where BRISTAR was mixed at a water ratio of $30 \%$.

Table V. Quantity of BRISTAR used per hole depth and the hole diameters.

\begin{tabular}{|l|l|c|c|c|c|c|c|c|c|}
\hline Hole Diameter & $(\mathrm{mm})$ & 36 & 38 & 40 & 42 & 44 & 46 & 48 & 50 \\
\hline BRISTAR & $(\mathrm{kg} / \mathrm{m})$ & 1.7 & 1.9 & 2.1 & 2.3 & 2.5 & 2.8 & 3.0 & 3.2 \\
\hline Hole Diameter & $(\mathrm{inch})$ & $1 \% / 8$ & $11 / 2$ & $1 \%$ & $1 \%$ & $1 \%$ & 2 \\
\hline BRISTAR & $(\mathrm{Lb} / \mathrm{yd})$ & 3.1 & 3.7 & 4.4 & 5.1 & 5.8 & 6.7 \\
\hline
\end{tabular}

6.2 Filling of the hole with BRISTAR

1. BRISTAR should be poured into holes within 10 minutes after mixing with water. BRISTAR may set up within 10 minutes loosing its fluid properties and becoming difficult to poor. Once its fluidity is gone, it should not be diluted by re-mixing with water, as the strength is greatly reduced.

II. BRISTAR is best placed using a bucket with pour spout, coking gun or grouting pump, especially for a horizontal hole. Try to drill horizontal holes with some slope to help in filling.

III. BRISTAR must be poured into a hole to the brim.

IV. For a horizontal hole, the hole can be easily plugged with BRISTAR as it reaches a clay like consistancy as it starts setting up. A slight slope makes their use much easier.

The average quantity of BRISTAR used per $1 \mathrm{~m}^{3}$ is $5 \mathrm{~kg}$ for the material to be broken when working at in virgin rock $(8,4 \mathrm{lb} / \mathrm{yd})$. For fragmentation and reinforced concrete, an amount of 2 to 4 times of that is required. Design the hole diameter and the spacing by also referring to Table IV or APPENDIX.

6.3 Use of polyethylene sack in hole

I. If there is water in the hole, place polyethylene thin sack equal to the hole diameter into the hole, inser a wooden rod into the bag and then fill BRISTAR into the sack. (See Fig. 8) The BRISTAR in the sack will displace the water in the hole. There is no change in the breaking effect by the use of this kind of sack.

II. When there are many joints or large voids in the material to be cracked or when BRISTAR somewhat leaks from the hole, use the sack.

III. When much water of the sluny is absorbed to the material to be cracked (for instance, a dry concrete), use the sack or spray water into the hole. In cold temperature, avoid the water sprayed freezing in the hole.

IV. When the material to be cracked is in water, use the sack indicated in Fig. 8. Try to use the bucket or the pump when filling into the pipe, remove it up, and then tie the sack to avoid BRISTAR filled diluting. If there is no flow of water around an entrance of the hole, BRISTAR may directly be poured into the hole using the pump so on. It should gently displace the water in the hole.

6.4 After Treatment

I. Tamping with mortar or sand is not required at all after the filling of BRISTAR. It is also not necessary to put on any restrictive cap. Just leave as it is and wait until crack initiates. Covering the filled hole with a plastic cover is desirable to avoid dilution of BRISTAR from extemal water source until cracking starts.

II. Spraying the surface with water after the cracks initiate tends to increase the width of cracks and speed the cracking process.

\section{TIME REQUIRED FOR CRACK FORMATION}

The time required for crack formation in material at $20^{\circ} \mathrm{C}\left(68^{\circ} \mathrm{F}\right)$ is about $10-20$ hours. The lower the temperature the longer crack formation takes. The crack width for rock continues to increase with time and can become $10-30 \mathrm{~mm}(3 / \mathrm{k}$ - $\mid 1 / 8 ")$ after several days, depending on free surfaces available. It is best to wait until the BRISTAR has worked to full depth before removing rock as premature removal at the first sign of a crack can hamper the leverage effect of BRISTAR. 


\section{CONTAINER AND STORAGE}

BRISTAR is packed in 4 anti-moisture bags of $5 \mathrm{~kg}$ (11 lb.) each and then placed in a water proofed carton with a total weight of approximately $20 \mathrm{~kg} \mathrm{(44}$ lb.).

1. Although BRISTAR is packed in anti-mositure paper bags, long storage may cause deterioration of its working ingredients. Therefore, store in a dry place and use it as soon as possible.

II. When storing, do not place the bags of BRISTAR directly on floor, put them on a pallet and keep in a dry warehouse etc. BRISTAR, stored in this manner, can be effectively used for about 1 year.

III. BRISTAR should be unpacked before use.

IV. When storing the portion of BRISTAR remaining after use, push the air out of the bag, then seal with gum tape and use as soon as possible. However, as it may get exposed to moisture there is risk of BRISTAR losing its effectiveness once the bag has been opened.

V. If you receive broken bags of BRISTAR, they may not work due to chance of moisture absorption.

\section{CAUTION}

1. Do not use BRISTAR for other purposes besides the cracking of rocks or concrete as instructed in this brochure.

II. Rinse with water, any portion of the skin that comes in contact with BRISTAR.

III. When mixing and filling BRISTAR in holes, wear rubber gloves and safety goggles.

IV. Do not pour and leave BRISTAR in bottle or can to avoid shattering of the can or bottle.

V. Do not look directly into any holes for at least 6 hours after pouring. BRISTAR may splatter or blow out of the hole due to heat generation when temperature of material to be broken is over temperatures in chart found on page one.

VI. Do not use hot water. Refer to chan found on page one.

\section{PRECAUTION}

In details, refer to CAUTION on Sec. 10 before using BRISTAR.

- Do not use BRISTAR for other purposes besides the cracking of material.

- Do not pour and leave BRISTAR in bottle or can.

- Do not look directly into any holes for at least 6 hours after filling.

- Use the proper type of BRISTAR listed in Table 1 (P.1).

- Do not use hot water.

- Wear rubber gloves and safety goggles when mixing and filling.

- Rinse with water when any portion of the skin comes in contact with BRISTAR. 


\section{Appendix B}

\section{Results of Field Coring of In situ Grouted Samples}


B-2 


\section{Appendix B}

\section{Results of Field Coring of In situ Grouted Samples}

This appendix contains the results of laboratory analysis of the compressive strength, hydraulic conductivity, and bulk density for Portland cement, soilcrete from the innovative grout/retrieval demonstration, and INEL soil. Portland cement was chosen as an inexpensive grout, in terms of material cost, and has the longest history of applications. Strength is determined by the water to Portland ratio as well as the percentage soil. The strength can be increased by the use of polymer. The polymer gives fluidity for pumping with less water, giving a denser Portland concrete and increasing the soil to Portland ratio. A polymer plasticizer additive was used in the laboratory and increased compressive strength by $30 \%$ but was not injected with the Portland concrete because premature hardening might occur.

At Westinghouse Hanford Company Laboratories, three 30-lb batches of soilcrete were prepared in a heavy duty laboratory mixer. The mixture was Portland cement and water in a 1-to- 1 weight ratio with 33,50 , and 67 wt\% soil and molded soilcrete cylinders $10 \times 20 \mathrm{~cm}(4 \times 8$ in.). Compressive strength testing was performed using American Society for Testing and Materials (ASTM)-39.

Idaho National Engineering Laboratory (INEL) personnel cored one of the 10 to 20 -lb soilcrete samples (cemented waste and soil) that were retrieved following the in situ grouting demonstration with a 1/2-in. carbide saw on a drill press. From about eight cores, four samples were sanded to an average $3.5 \times 1 \mathrm{~cm}(1.4 \times 0.4 \mathrm{in}$.) regular cylindrical shape and submitted for compressive strength analysis. INEL personnel performed the compressive strength testing.

A summary of the laboratory and field coring data (from the FY-94 demonstration) is given in Tables B-1 and B-2. Compressive strengths were at least 20 times the Nuclear Regulatory Commission's 50 PSI limit on Portland formulations even after the short curing time of 14 days. The results of strength versus soil loading are graphed on Figure B-1 with the strength from the field sample inserted. The soilcrete formulation that sufficiently fills all available voids assuming 35 to $40 \%$ porosity did give sufficient strength (>500 psi) to the soil. 
Table B-1. Physical characteristics of Portland cement, Radioactive Waste Management Complex soil, and in situ generated soilcrete.

\begin{tabular}{|c|c|c|c|c|}
\hline Property & Units & Soilcrete & Soil & Portland \\
\hline Bulk density & $\mathrm{g} / \mathrm{cc}$ & $1.38 \pm 0.02$ & $1.66 \pm 0.25$ & 1.51 \\
\hline Specific gravity & $\mathrm{g} / \mathrm{cc}$ & $\mathbf{N A}$ & 2.86 & 3.15 \\
\hline Estimated porosity & percent & 25 & 39 & 0.5 \\
\hline Vertical hydraulic conduct & $\begin{array}{l}\mathrm{cm} / \mathrm{s} \\
\text { (estimated) }\end{array}$ & $10^{-6}-10^{-8}$ & $10^{-3}-10^{-6}$ & $10^{-7}-10^{-10}$ \\
\hline Compressive strength & psi & $1215 \pm 128$ & 690 & 4000 \\
\hline Soil content & $w t \%$ & 39 & 100 & $<1$ \\
\hline Moisture content & wt \% & 7 & 11 & 2 \\
\hline Clay minerals & wt \% & 22 & 47 & 2 \\
\hline Quartz as $\mathrm{SiO}_{2}$ & wt \% & 9 & 24 & 4 \\
\hline Calcite as $\mathrm{CaCO}_{3}$ & wt \% & 20 & 1 & 50 \\
\hline
\end{tabular}

Table B-2. Comparison of laboratory prepared and field in-situ generated soilcrete laboratory.

\begin{tabular}{|c|c|c|c|c|}
\hline \multirow[b]{2}{*}{ Property } & \multicolumn{3}{|c|}{$\begin{array}{l}\text { Soil content } \\
\text { (wt\%) }\end{array}$} & \multirow{2}{*}{$\begin{array}{c}\text { Field soil } \\
\text { content } \\
\text { (wt\%) }\end{array}$} \\
\hline & 33.3 & 50 & 60.7 & \\
\hline Bulb density ( $g / c c)$ & 1.6 & 1.3 & 1.3 & $1.38 \pm 0.02$ \\
\hline Compression strength (psi) & $1240 \pm 40$ & $1170 \pm 40$ & $890 \pm 10$ & $1220 \pm 130$ \\
\hline
\end{tabular}




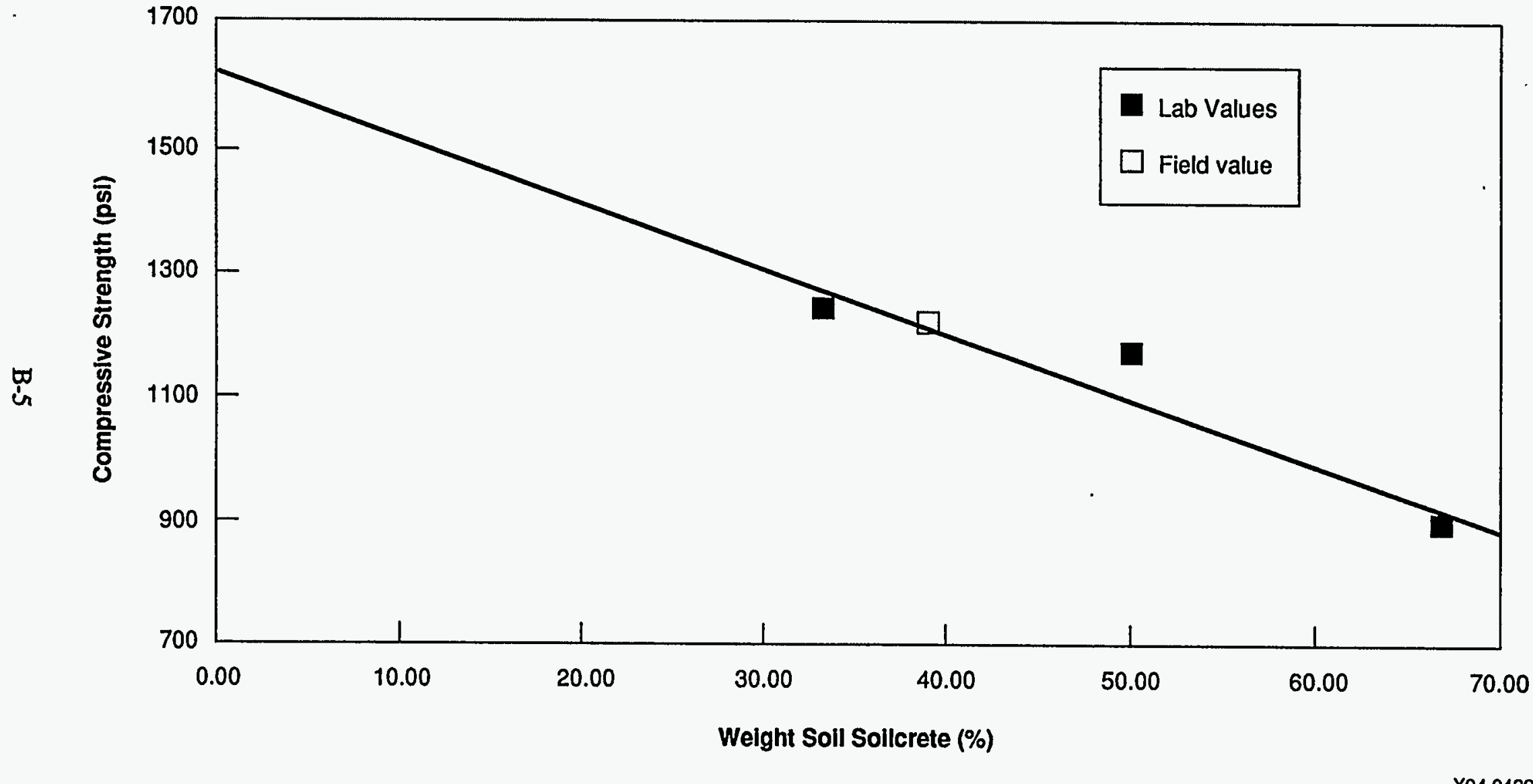

Figure B-1. Strength of INEL soilcrete. 


\section{Appendix C}

\section{Data from Air Monitoring}

C-1 
C-2 


\section{Appendix C}

\section{Data from Air Monitoring}

This appendix contains the data for the various air monitor strategically located around the grouting or retrieval activities. Figure C-1 summarizes the location of the samplers relative to the pit. 


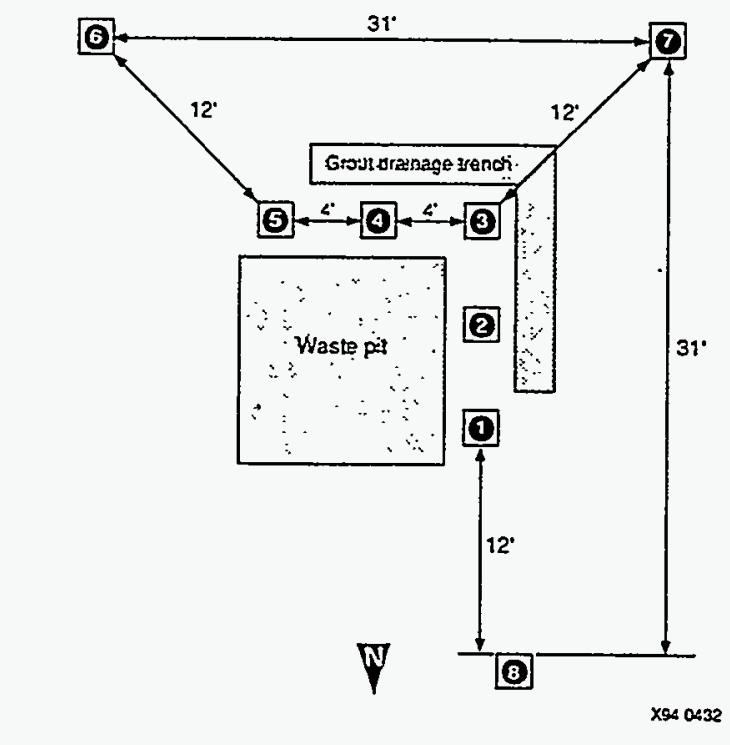

High volume air sampler arrangement for grout injection test, G1 - G7 and background test.

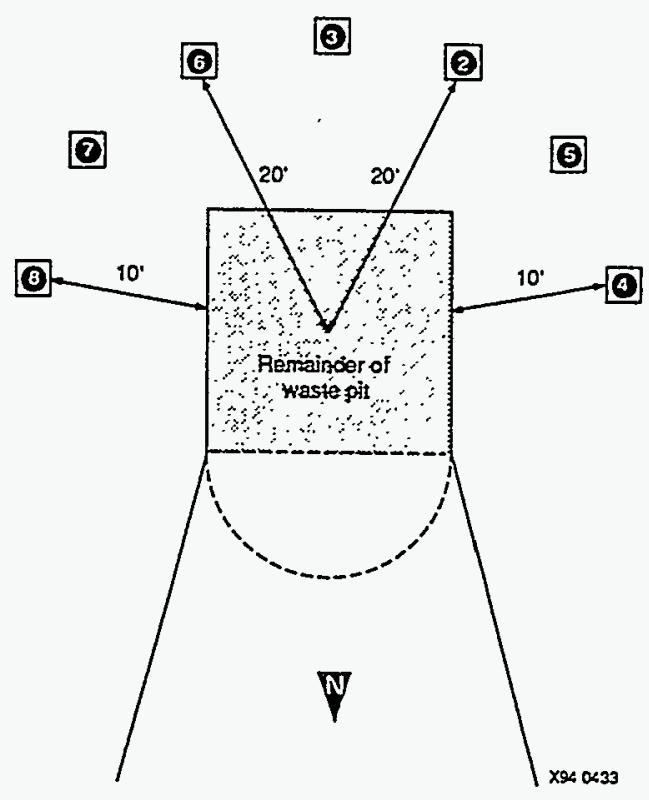

High volume air sampler arrangement for retrieval tests, $R 5$ and baseline retrieval test BR2

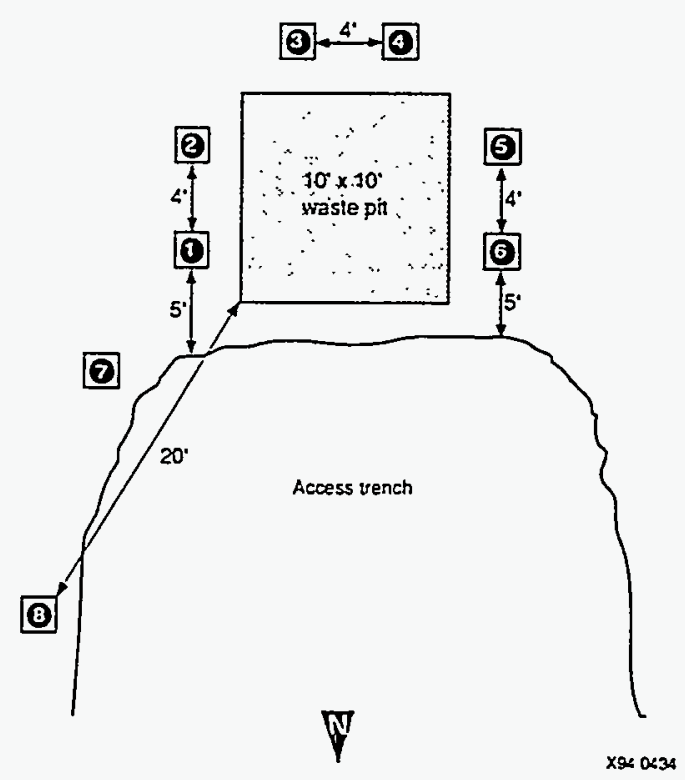

High volume air sampler arrangement lor retrieval tests, R1-R4

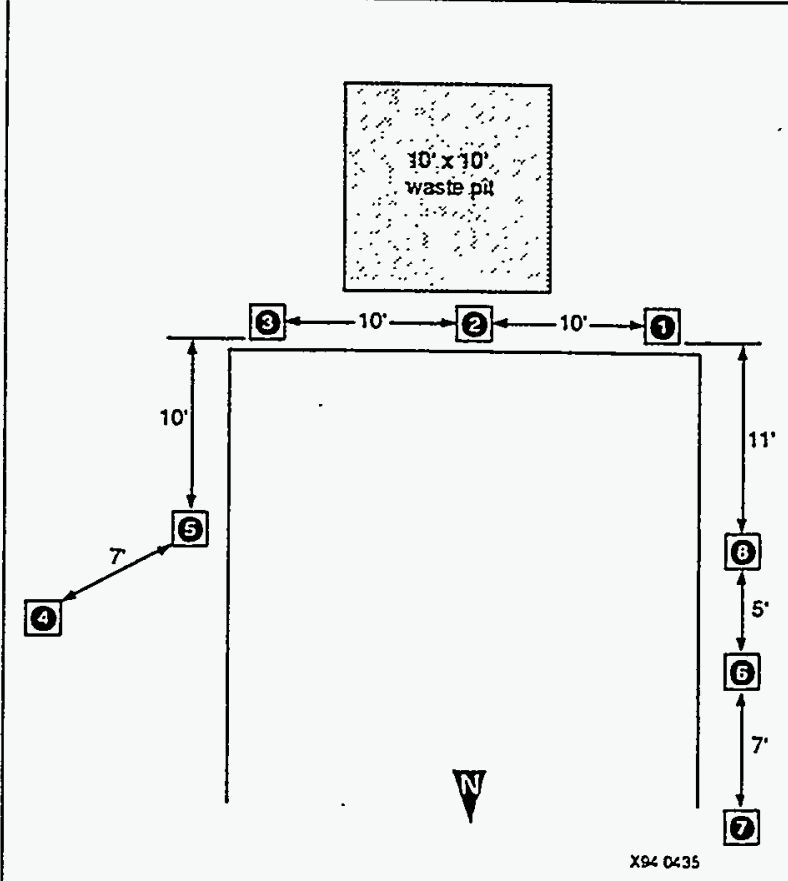

High volume air sampler arrangement for baseline retrieval test, BR1

$\times 940444$

Figure C-1. Location of samplers relative to the pit for grouting $(G)$ and retrieval (R). 
INNOVATIVE GROUT INJECTION AND RETRIEVAL

Test G1

TEMPERATURE: $\quad 88 \mathrm{~F}$
SAMPLING TIME:
$28 \mathrm{~min}$

BAROMETRIC PRESS: $842 \mathrm{mb}$

\begin{tabular}{|c|c|}
\hline Hi vol & Filter mass \\
\hline 1 & 0.0737 \\
\hline 2 & 0.0711 \\
\hline 3 & 0.0590 \\
\hline 4 & 0.0666 \\
\hline 5 & 0.0513 \\
\hline 6 & 0.0363 \\
\hline 7 & 0.0648 \\
\hline 8 & 0.0831 \\
\hline & \\
\hline AVG & 0.0632 \\
\hline
\end{tabular}

DATA INVALIDATED DUE TO GROUT INJECTION PROBLEMÁS:

a) only one hole was injected which created a partial floor under the pit,

b) injector pump had priming problems because the grout was starting to set up too fast, and

c) a valve plugged up the stinger and WHC had to take the system apart. 
Test G2

TEMPERATURE: $\quad 56 \mathrm{~F}$

SAMPLING TIME: $\quad 78 \mathrm{~min}$

BAROMETRIC PRESS: $843 \mathrm{mb}$

\begin{tabular}{|c|c|}
\hline Hi vol & $\begin{array}{c}\text { Net mass of dust } \\
\text { on filter }\end{array}$ \\
\hline 1 & 0.0525 \\
\hline 2 & 0.0508 \\
\hline 3 & 0.0503 \\
\hline 4 & 0.0668 \\
\hline 5 & 0.0541 \\
\hline 6 & 0.0544 \\
\hline 7 & 0.0561 \\
\hline 8 & 0.0509 \\
\hline & \\
\hline AVG & 0.0545 \\
\hline
\end{tabular}

DATA INVALIDATED DUE TO GROUT INJECTION PROBLEMS:

a)

the first hole continued to be injected which added to the partial floor under the pit started in G-1. 
TEMPERATURE: $\quad 78 \mathrm{~F}$

SAMPLING TIME: $\quad 94 \mathrm{~min}$

BAROMETRIC PRESS: $841 \mathrm{mb}$

\begin{tabular}{|c|c|c|c|c|c|c|c|c|c|c|}
\hline Hi vol & $\begin{array}{l}\text { Net mass of } \\
\text { dust on } \\
\text { fitters } \\
\text { (g) }\end{array}$ & $\begin{array}{c}\text { Net } \mu \mathrm{g} \mathrm{Pr} \\
\text { (total-avg blank) }\end{array}$ & $\begin{array}{l}\mu \mathrm{g} / \mathrm{g} \mathrm{Pr} \\
\text { in dust }\end{array}$ & $\begin{array}{l}\text { Fow rate } \\
\text { (CFM) }\end{array}$ & $\begin{array}{c}\text { Tracer } \\
\text { concentration } \\
\text { ( } \mu \mathrm{g} / \mathrm{g} \mathrm{Pr} / \mathrm{CF} \text {-air) }\end{array}$ & $\begin{array}{c}\text { Dust } \\
\text { concentration } \\
\text { (g/L-air) }\end{array}$ & $\begin{array}{c}\text { Tracer } \\
\text { concentration } \\
\text { background } \\
\text { corrected }\end{array}$ & $\begin{array}{l}\text { STD DEV } \\
\text { (2 sigma) }\end{array}$ & $\begin{array}{c}\text { Dust } \\
\text { concentration } \\
\text { (g/L-air) } \\
\text { background } \\
\text { corrected }\end{array}$ & $\begin{array}{c}\text { STD DEV } \\
\text { (2 sigma) }\end{array}$ \\
\hline 1 & 0.1229 & 0.7913 & 6.44 & 16.3 & $4.20 \mathrm{E}-03$ & 2.63E-07 & $1.18 \mathrm{E}-03$ & & 2.12E- -07 & \\
\hline 2 & 0.1146 & 0.7378 & 6.44 & 16.4 & $4.18 \mathrm{E}-03$ & $2.44 \mathrm{E}-07$ & $1.15 \mathrm{E}-03$ & & 1.93E- -07 & \\
\hline 3 & 0.0968 & 0.6207 & 6.41 & 14.5 & $4.70 \mathrm{E}-03$ & 2.33E-07 & $1.68 \mathrm{E}-03$ & & $1.82 \mathrm{E}-07$ & \\
\hline 4 & 0.1191 & 0.8621 & 7.24 & 15.6 & $4.94 \mathrm{E}-03$ & $2.66 \mathrm{E}-07$ & $1.91 \mathrm{E}-03$ & & 2.15E-07 & \\
\hline 5 & 0.1005 & 0.6916 & 6.88 & 15.0 & $4.88 \mathrm{E}-03$ & 2.34E-07 & $1.85 \mathrm{E}-03$ & & 1.83E- -07 & \\
\hline 6 & 0.0817 & 0.5629 & 6.89 & 16.7 & $4.39 \mathrm{E}-03$ & $1.71 \mathrm{E}-07$ & $1.36 \mathrm{E}-03$ & & $1.19 \mathrm{E}-07$ & \\
\hline 7 & 0.0924 & 0.5554 & 6.01 & 17.1 & $3.74 E-03$ & $1.89 \mathrm{E}-07$ & $7.14 \mathrm{E}-04$ & & 1.37E-07 & \\
\hline 8 & 0.1065 & 1.0547 & 9.90 & 16.9 & $6.23 \mathrm{E}-03$ & $2.20 \mathrm{E}-07$ & $3.21 \mathrm{E}-03$ & & $1.69 \mathrm{E}-07$ & \\
\hline AVG & 0.1043 & 0.7346 & 7.03 & 16.06 & $4.66 \mathrm{E}-03$ & 2.27E-07 & $1.63 \mathrm{E}-03$ & $\pm 1.14 \mathrm{E}-03$ & $1.76 \mathrm{E}-07$ & $\pm 6.29 \mathrm{E}-08$ \\
\hline
\end{tabular}

NOTE: Five holes were drilled and grouted during the G-3 test. 
TEMPERATURE:

SAMPLING TIME:

$84 \mathrm{~F}$

BAROMETRIC PRESS: $838 \mathrm{mb}$

\begin{tabular}{|c|c|}
\hline Hi vol & $\begin{array}{c}\text { Net filter mass } \\
\text { (grams) }\end{array}$ \\
\hline 1 & 0.0605 \\
\hline 2 & 0.0580 \\
\hline 3 & 0.0725 \\
\hline 4 & 0.0878 \\
\hline 5 & 0.0519 \\
\hline 6 & 0.0620 \\
\hline 7 & 0.0746 \\
\hline 8 & 0.0791 \\
\hline & \\
\hline AVG & 0.0683 \\
\hline
\end{tabular}

NOTE: $\quad$ Four holes were drilled and grouted during this test.

\section{DATA INVALIDATED DUE TO GROUT INJECTION PROBLEMS:}

b)

breakers on power strips connected to Hi Vol samplers tripped during test, HEPA system was not on full time during this test,

drill stem had a hydraulic leak during testing and had to be fixed. 
TEMPERATURE: $\quad 55 \mathrm{~F}$

SAMPLING TIME: $177 \mathrm{~min}$

BAROMETRIC PRESS: $843 \mathrm{mb}$

\begin{tabular}{|c|c|c|c|c|c|c|c|c|}
\hline Hi vol & $\begin{array}{l}\text { Net mass of dust } \\
\text { on filter } \\
\text { (g) }\end{array}$ & $\begin{array}{c}\text { Net } \mu \mathrm{g} \text { Pr } \\
\text { (total-avg blank) }\end{array}$ & $\begin{array}{l}\mu \mathrm{g} / \mathrm{g} \mathrm{Pr} \\
\text { in dust }\end{array}$ & $\begin{array}{l}\text { Flow rate } \\
\text { (CFM) }\end{array}$ & $\begin{array}{c}\text { Tracer } \\
\text { concentration } \\
(\mu \mathrm{g} / \mathrm{g} \mathrm{Pr} / \mathrm{CF} \text {-air) }\end{array}$ & $\begin{array}{c}\text { Dust } \\
\text { concentration } \\
\text { (g/L-air) }\end{array}$ & $\begin{array}{c}\text { Tracer } \\
\text { concentration } \\
\text { ( } \mu \text { g/g } \mathrm{Pr} / \mathrm{CF} \text {-air) } \\
\text { background } \\
\text { corrected }\end{array}$ & $\begin{array}{l}\text { STD DEV } \\
\text { (2 sigma) }\end{array}$ \\
\hline 1 & 0.0782 & No data & No data & & & & & \\
\hline 2 & 0.0811 & No data & No data & & & & & \\
\hline 3 & 0.1120 & 1.6622 & 14.84 & 13.5 & $6.21 \mathrm{E}-03$ & $1.54 \mathrm{E}-07$ & 3.19E-03 & \\
\hline 4 & 0.1309 & 1.1481 & 8.77 & 15.2 & $3.26 \mathrm{E}-03$ & $1.60 \mathrm{E}-07$ & 2.35E04 & \\
\hline 5 & 0.0759 & No data & No data & & & & & \\
\hline 6 & 0.1018 & 0.9710 & 9.54 & 17.3 & $3.12 \mathrm{E}-03$ & $1.09 \mathrm{E}-07$ & $9.09 \mathrm{E}-05$ & \\
\hline 7 & 0.1125 & 1.2123 & 10.78 & 18.0 & 3.38E-03 & $1.16 \mathrm{E}-07$ & 3.59E-04 & \\
\hline 8 & 0.1034 & 1.0459 & 10.12 & 17.5 & $3.27 \mathrm{E}-03$ & $1.10 \mathrm{E}-07$ & 2.42E-04 & \\
\hline AVG & 0.0995 & 1.21 & 10.81 & 16.30 & $3.85 \mathrm{E}-03$ & $1.30 \mathrm{E}-07$ & $8.23 \mathrm{E}-04$ & $\pm 2.37 \mathrm{D} .93$ \\
\hline
\end{tabular}

NOTE: Due to a power interruption, data was not reported for HV-1, HV-2, and HV-5 (accurate flow rates could not be calculated). Seven holes were drilled and grouted during this test. 
TEMPERATURE: $\quad 80 \mathrm{f}$

SAMPLING TIME: $220 \mathrm{~min}$

BAROMETRIC PRESS: $842 \mathrm{mB}$

\begin{tabular}{||c|c|}
\hline \hline Hi vol & $\begin{array}{c}\text { Net filter mass } \\
\text { (grams) }\end{array}$ \\
\hline 1 & 0.2332 \\
\hline 2 & 0.2296 \\
\hline 3 & 0.1706 \\
\hline 4 & 0.2218 \\
\hline 5 & 0.1929 \\
\hline \multirow{0}{0}{} & 0.1796 \\
\hline 6 & 0.1456 \\
\hline 7 & 0.1687 \\
\hline 8 & \\
\hline & 0.1928 \\
\hline AVG & \\
\hline
\end{tabular}

\section{DATA INVALIDATED DUE TO GROUT INJECTION PROBLEMS:}

a) breakers on power strips connected to Hi Vol samplers tripped during test,

b) Hi Vol filters were left on the samplers overnight - WHC unknowingly disrupted considerable dust the next day while cleaning up the pit surface when preparing for the G-7 test. Analysis of the filters from the G-6 test had to be aborted. 
TEMPERATURE: $\quad 86 \mathrm{~F}$

SAMPLING TIME: $245 \mathrm{~min}$

BAROMETRIC PRESS: $841 \mathrm{mB}$

\begin{tabular}{|c|c|c|c|c|c|c|c|c|c|c|}
\hline Hi vol & $\begin{array}{l}\text { Net mass of } \\
\text { dust on } \\
\text { filter } \\
\text { (g) }\end{array}$ & $\begin{array}{c}\text { Net } \mu \mathrm{g} \mathrm{Pr} \\
\text { (total-avg blank) }\end{array}$ & $\begin{array}{l}\mu \mathrm{g} / \mathrm{g} \mathrm{Pr} \\
\text { in dust }\end{array}$ & $\begin{array}{l}\text { Flow rate } \\
\text { (CFM) }\end{array}$ & $\begin{array}{c}\text { Tracer } \\
\text { concentration } \\
\text { ( } \mu \mathrm{g} / \mathrm{g} \mathrm{Pr} / \mathrm{CF} \text {-air) }\end{array}$ & $\begin{array}{c}\text { Dust } \\
\text { concentration } \\
\text { (g/L-air) }\end{array}$ & $\begin{array}{c}\text { Tracer } \\
\text { concentration } \\
\text { ( } \mu \mathrm{g} / \mathrm{g} \mathrm{Pr/CF-air)} \\
\text { background } \\
\text { corrected }\end{array}$ & $\begin{array}{l}\text { STD DEV } \\
\text { (2 sigma) }\end{array}$ & $\begin{array}{c}\text { Dust } \\
\text { concentration } \\
\text { (g/L-air) } \\
\text { background } \\
\text { corrected }\end{array}$ & $\begin{array}{l}\text { STD DEV } \\
\text { (2 sigma) }\end{array}$ \\
\hline 1 & 0.2477 & 1.8780 & 7.58 & 13.7 & $2.26 \mathrm{E}-03$ & 2.43E-07 & $-7.61 \mathrm{E}-04$ & & $1.91 \mathrm{E}-07$ & \\
\hline 2 & 0.2194 & 1.7201 & 7.84 & 15.5 & 2.07E-03 & $1.90 \mathrm{E}-07$ & $-9.55 \mathrm{E}-04$ & & $1.39 \mathrm{E}-07$ & \\
\hline 4 & 0.2820 & 2.6404 & 9.36 & 15.9 & 241E-03 & 2.38E-07 & $6.17 \mathrm{E}-04$ & & $1.87 \mathrm{E}-07$ & \\
\hline 5 & 0.2364 & 20080 & 8.49 & 14.2 & 2.44E-03 & 2.22E- -07 & $5.89 \mathrm{E}-04$ & & 1.71E-07 & \\
\hline 6 & 0.2387 & 2.0838 & 8.73 & 14.6 & $2.43 \mathrm{E}-03$ & $2.18 \mathrm{E}-07$ & $5.91 \mathrm{E}-04$ & & 1.67E-07 & \\
\hline 7 & 0.1645 & 1.2694 & 7.72 & 17.8 & $1.77 \mathrm{E}-03$ & $1.24 \mathrm{E}-07$ & $1.26 \mathrm{E}-03$ & & 7.23E-08 & \\
\hline
\end{tabular}

NOTE: Twenty holes were drilled and grouted in this test. 
Test BACKGROUND

TEMPERATURE: $\quad 68 \mathrm{~F}$

SAMPLING TIME: $\quad 120 \mathrm{~min}$

BAROMETRIC PRESS: $841 \mathrm{mb}$

\begin{tabular}{|c|c|c|c|c|c|c||}
\hline Hi vol & $\begin{array}{c}\text { Net mass of } \\
\text { dust on filter } \\
(\mathrm{g})\end{array}$ & $\begin{array}{c}\text { Net } \mu \mathrm{g} \text { Pr } \\
\text { (total-avg blank) }\end{array}$ & $\begin{array}{c}\mu \mathrm{g} / \mathrm{g} \text { Pr } \\
\text { in dust }\end{array}$ & $\begin{array}{c}\text { Flow rate } \\
(\mathrm{CFM})\end{array}$ & $\begin{array}{c}\text { Tracer } \\
\text { concentration } \\
(\mu \mathrm{g} / \mathrm{g} \text { Pr/CF-air) })\end{array}$ & $\begin{array}{c}\text { Dust } \\
\text { concentration } \\
(\mathrm{g} / \mathrm{L}-\text { air })\end{array}$ \\
\hline 1 & 0.0281 & 0.1975 & 7.03 & 18.5 & $3.18 \mathrm{E}-03$ & $4.16 \mathrm{E}-08$ \\
\hline 2 & 0.0284 & 0.1402 & 4.94 & 17.3 & $2.38 \mathrm{E}-03$ & $4.48 \mathrm{E}-08$ \\
\hline 3 & 0.0379 & 0.2463 & 6.50 & 15.4 & $3.52 \mathrm{E}-03$ & $6.74 \mathrm{E}-08$ \\
\hline $\mathbf{S}$ & 0.0262 & No data & No data & No data & No data & No data \\
\hline 5 & 0.0221 & No data & No data & No data & No data & No data \\
\hline 6 & 0.0219 & No data & No data & No data & No data & No data \\
\hline 7 & 0.0263 & No data & No data & No data & No data & No data \\
\hline 8 & 0.0285 & No data & No data & No data & No data & No data \\
\hline & & & & & & \\
\hline AVG & 0.0274 & 0.19 & 6.16 & 17.05 & $3.02 \mathrm{E}-03$ & $5.13 \mathrm{E}-08$ \\
\hline
\end{tabular}

NOTE: Data was not analyzed for Pr tracer where indicated. 
TEMPERATURE: $\quad 72 \mathrm{~F}$

SAMPLING TIME: $120 \mathrm{~min}$

BAROMETRIC PRESS: $841 \mathrm{mb}$

\begin{tabular}{|c|c|c|c|c|c|c|c|c|c|c|}
\hline Hi vol & $\begin{array}{l}\text { Net mass of } \\
\text { dust on } \\
\text { filter } \\
\text { (g) }\end{array}$ & $\begin{array}{c}\text { Net } \mu \mathrm{g} P r \\
\text { (total-avg } \\
\text { blank) }\end{array}$ & $\begin{array}{l}\mu \mathrm{g} / \mathrm{g} \mathrm{Pr} \\
\text { in dust }\end{array}$ & $\begin{array}{c}\text { Flow rate } \\
\text { (CFM) }\end{array}$ & $\begin{array}{c}\text { Tracer } \\
\text { concentration } \\
\text { ( } \mu \mathrm{g} / \mathrm{g} \mathrm{Pr} / \mathrm{CF} \text {-air) }\end{array}$ & $\begin{array}{c}\text { Dust } \\
\text { concentration } \\
\text { (g/L-air) }\end{array}$ & $\begin{array}{c}\text { Tracer } \\
\text { concentration } \\
(\mu \mathrm{g} / \mathrm{g} \mathrm{Pr} / \mathrm{CF} \text {-air) } \\
\text { background } \\
\text { corrected }\end{array}$ & $\begin{array}{l}\text { STD DEV } \\
\text { (2 sigma) }\end{array}$ & $\begin{array}{c}\text { Dust } \\
\text { concentration } \\
\text { (g/L-air) } \\
\text { background } \\
\text { corrected }\end{array}$ & $\begin{array}{c}\text { STD DEV } \\
\text { (2 sigma) }\end{array}$ \\
\hline 1 & 0.2607 & 2.8059 & 10.76 & 16.3 & $5.50 \mathrm{E}-03$ & 4.37E-07 & $2.48 \mathrm{E}-03$ & & $3.86 \mathrm{E}-07$ & \\
\hline 2 & 0.3078 & 2.8211 & 9.17 & 16.4 & $4.66 \mathrm{E}-03$ & 5.13E-07 & $1.63 \mathrm{E}-03$ & & 4.62E-07 & \\
\hline 3 & 0.2381 & 2.0597 & 8.65 & 14.5 & 4.97E-03 & $4.49 \mathrm{E}-07$ & $1.95 \mathrm{E}-03$ & & $3.98 \mathrm{E}-07$ & \\
\hline 4 & 0.1982 & No data & No data & No data & No data & No data & No data & & No data & \\
\hline 5 & 0.2040 & No data & No data & No data & No data & No data & No data & & No data & \\
\hline 6 & 0.2093 & No data & No data & No data & No data & No data & No data & & No data & \\
\hline 7 & 0.2325 & No data & No data & No data & No data & No data & No data & & No data & \\
\hline 8 & 0.2362 & No data & No data & No data & No data & No data & No data & & No data & \\
\hline AVG & 0.2359 & 2.5622 & 9.5267 & 15.7333 & $5.04 \mathrm{E}-03$ & $5.04 \mathrm{E}-03$ & $2.02 E-03$ & $\pm 6.95 \mathrm{E}-04$ & $4.15 \mathrm{E}-07$ & $\pm 6.67 \mathrm{E}-\mathrm{n} 8$ \\
\hline
\end{tabular}

NOTE: $\quad$ Data was not analyzed for Pr tracer where indicated. 
Test R1

TEMPERATURE: $\quad 84 \mathrm{~F}$

SAMPLING TIME: $\quad 49 \mathrm{~min}$

BAROMETRIC PRESS: $841 \mathrm{mb}$

\begin{tabular}{|c|c|}
\hline Hi vol & $\begin{array}{c}\text { Net filter mass } \\
\text { (grams) }\end{array}$ \\
\hline 1 & 0.0472 \\
\hline 2 & 0.0497 \\
\hline 3 & 0.0365 \\
\hline 4 & 0.0407 \\
\hline 5 & 0.0423 \\
\hline 5 & 0.0594 \\
\hline 7 & 0.0463 \\
\hline 8 & 0.0583 \\
\hline 5 & \\
\hline AVG & 0.0476 \\
\hline
\end{tabular}

Data was not anatyzed because grouted pit was not yet exposed and no grout or waste was removed (only soil was removed). 
TEMPERATURE: $\quad 84 \mathrm{~F}$

SAMPLING TIME: $9 \mathrm{~min}$

BAROMETRIC PRESS: $841 \mathrm{mb}$

\begin{tabular}{|c|c|}
\hline Hi vol & $\begin{array}{l}\text { Net filter mass } \\
\text { (grams) }\end{array}$ \\
\hline 1 & 0.0659 \\
\hline 2 & 0.0583 \\
\hline 3 & 0.0441 \\
\hline 4 & 0.0382 \\
\hline 5 & 0.0308 \\
\hline 6 & 0.0400 \\
\hline 7 & 0.0466 \\
\hline 8 & 0.0688 \\
\hline AVG & 0.0491 \\
\hline
\end{tabular}

This test was aborted due to high winds and a large dust storm entering the tent - retricval operations were aborted. 
TEMPERATURE: $\quad 78 \mathrm{~F}$

SAMPLING TIME: $\quad 90 \mathrm{~min}$

BAROMETRIC PRESS: $841 \mathrm{mb}$

\begin{tabular}{|c|c|c|c|c|c|c|c|c|c|c|}
\hline Hi vol & $\begin{array}{l}\text { Net mass of } \\
\text { dust on } \\
\text { filter } \\
\text { (g) }\end{array}$ & $\begin{array}{l}\text { Net } \mu \mathrm{g} \mathrm{Pr} \\
\text { (total-avg } \\
\text { blank) }\end{array}$ & $\begin{array}{l}\mu \mathrm{g} / \mathrm{g} \mathrm{Pr} \\
\text { in dust }\end{array}$ & $\begin{array}{l}\text { Flow rate } \\
\text { (CFM) }\end{array}$ & $\begin{array}{c}\text { Tracer } \\
\text { concentration } \\
\text { ( } \mu \mathrm{g} / \mathrm{g} \mathrm{Pr} / \mathrm{CF}- \\
\text { air })\end{array}$ & $\begin{array}{c}\text { Dust } \\
\text { concentration } \\
\text { (g/L-air) }\end{array}$ & $\begin{array}{c}\text { Tracer } \\
\text { concentration } \\
\text { ( } \mu \mathrm{g} / \mathrm{g} \mathrm{Pr} / \mathrm{CF} \text {-air) } \\
\text { background } \\
\text { corrected }\end{array}$ & $\begin{array}{l}\text { STD DEV } \\
\text { (2 sigma) }\end{array}$ & $\begin{array}{c}\text { Dust } \\
\text { concentration } \\
\text { (g/L-air) } \\
\text { background } \\
\text { corrected }\end{array}$ & $\begin{array}{c}\text { STD DEV } \\
\text { (2 sigma) }\end{array}$ \\
\hline 1 & 0.1074 & 234 & 2176 & 11.7 & $2.07 \mathrm{E}+00$ & 3.35E-07 & $2.07 \mathrm{E}+00$ & & $2.84 \mathrm{E}-07$ & \\
\hline 2 & 0.1056 & 213 & 2012 & 13.9 & $1.61 E+00$ & 2.77E-07 & $1.61 \mathrm{E}+00$ & & $2.26 \mathrm{E}-07$ & \\
\hline 3 & 0,0843 & 127 & 1503 & 12.0 & $1.39 E+00$ & $2.56 \mathrm{E}-07$ & $1.39 \mathrm{E}+00$ & & 2.04E-07 & \\
\hline 4 & 0.0886 & 145 & 1637 & 13.8 & $1.32 \mathrm{E}+00$ & 2.34E-07 & $1.32 \mathrm{E}+\infty 0$ & & $1.83 \mathrm{E}-07$ & \\
\hline 5 & 0.0879 & 117 & 1334 & 12.3 & $1.20 \mathrm{E}+00$ & $2.60 \mathrm{E}-07$ & $1.20 \mathrm{E}+\infty 0$ & & $2.09 \mathrm{E}-07$ & \\
\hline 6 & 0.1306 & 240 & 1835 & 12.7 & $1.61 \mathrm{E}+00$ & $3.75 \mathrm{E}-07$ & $1.60 \mathrm{E}+\infty 0$ & & $3.24 \mathrm{E}-07$ & \\
\hline 7 & 0.0964 & 164 & 1701 & 13.3 & $1.43 E+00$ & $2.65 \mathrm{E}-07$ & $1.42 \mathrm{E}+\infty 0$ & & 2.14E-07 & \\
\hline 8 & 0.1102 & 124 & 1126 & 13.5 & $9.29 \mathrm{E}-01$ & $2.98 \mathrm{E}-07$ & $9.26 \mathrm{E}-01$ & & 2.47E-07 & \\
\hline AVG & 0.1014 & 170.5 & 1665.5 & 12.89 & $1.44 \mathrm{E}+00$ & $2.88 \mathrm{E}-07$ & $1.44 \mathrm{E}+00$ & $\pm 6.29 \mathrm{E}-01$ & $2.36 \mathrm{E}-07$ & $\pm 8.75 \mathrm{E}-08$ \\
\hline
\end{tabular}


TEMPERATURE: $\quad 86 \mathrm{~F}$

SAMPLING TIME: $\quad 57 \mathrm{~min}$

BAROMETRIC PRESS: $841 \mathrm{mb}$

\begin{tabular}{|c|c|c|c|c|c|c|c|c|c|c|}
\hline Hi vol & $\begin{array}{l}\text { Net mass of } \\
\text { dust on filter } \\
\text { (g) }\end{array}$ & $\begin{array}{c}\text { Net } \mu \mathrm{g} \mathrm{Pr} \\
\text { (total-avg blank) }\end{array}$ & $\begin{array}{c}\mu \mathrm{g} / \mathrm{g} \mathrm{Pr} \text { in } \\
\text { dust }\end{array}$ & $\begin{array}{l}\text { Flow rate } \\
\text { (CFM) }\end{array}$ & $\begin{array}{c}\text { Tracer } \\
\text { concentration } \\
\text { ( } \mu \mathrm{g} / \mathrm{g} \mathrm{Pr} / \mathrm{CF} \text {-air) }\end{array}$ & $\begin{array}{c}\text { Dust } \\
\text { concentration } \\
\text { (g/L-air) }\end{array}$ & $\begin{array}{c}\text { Tracer } \\
\text { concentration } \\
\text { ( } \mu \mathrm{g} / \mathrm{g} \mathrm{Pr} / \mathrm{CF} \text {-air) } \\
\text { background } \\
\text { corrected }\end{array}$ & $\begin{array}{l}\text { STD DEV } \\
\text { (2 sigma) }\end{array}$ & $\begin{array}{c}\text { Dust } \\
\text { concentration } \\
\text { (g/L-air) } \\
\text { background } \\
\text { corrected }\end{array}$ & $\begin{array}{c}\text { STD DEV } \\
\text { (2 sigma) }\end{array}$ \\
\hline 1 & 0.0869 & 979 & 11263 & 14.3 & $1.38 \mathrm{E}+01$ & 3.51E-07 & $1.38 \mathrm{E}+01$ & & $2.99 \mathrm{E}-07$ & \\
\hline 2 & 0.0826 & 880 & 10651 & 15.0 & $1.25 \mathrm{E}+01$ & 3.17E-07 & $1.25 \mathrm{E}+01$ & & 2.66E-07 & \\
\hline 3 & 0.0573 & 224 & 3908 & 12.0 & $5.74 \mathrm{E}+00$ & $2.76 \mathrm{E}-07$ & $5.73 E+00$ & & 2.25E-07 & \\
\hline 4 & 0.0566 & 194 & 3432 & 13.7 & $4.39 \mathrm{E}+00$ & 2.37E-07 & $4.38 \mathrm{E}+00$ & & $1.86 \mathrm{E}-07$ & \\
\hline 5 & 0.0532 & 274 & 5145 & 12.5 & $7.23 \mathrm{E}+\infty 0$ & 2.45E-07 & $7.23 \mathrm{E}+00$ & & $1.94 \mathrm{E}-07$ & \\
\hline 6 & 0.0771 & 375 & 4866 & 13.4 & $6.36 \mathrm{E}+00$ & 3.31E-07 & $6.36 \mathrm{E}+00$ & & 2.79E-07 & \\
\hline 7 & 0.0767 & 363 & 4736 & 14.3 & $5.83 \mathrm{E}+\infty 0$ & 3.10E-07 & $5.82 \mathrm{E}+00$ & & $2.58 \mathrm{E}-07$ & \\
\hline 8 & 0.1083 & 745 & 6874 & 13.3 & $9.05 \mathrm{E}+00$ & $4.68 \mathrm{E}-07$ & $9.05 \mathrm{E}+00$ & & 4.17E-07 & \\
\hline AVG & 0.0748 & 504.3 & 6359.4 & 13.55 & $8.11 E+00$ & $3.17 \mathrm{E}-07$ & $8.11 E \div 00$ & $\pm 6.38 \mathrm{E}+00$ & $2.66 \mathrm{E}-07$ & $\doteq 1.37 \mathrm{E}-07$ \\
\hline
\end{tabular}


Test R5

TEMPERATURE: $\quad 78 \mathrm{~F}$

SAMPLING TIME: $\quad 91 \mathrm{~min}$

BAROMETRIC PRESS: $841 \mathrm{mb}$

\begin{tabular}{|c|c|c|c|c|c|c|c|c|c|c|}
\hline Hi vol & $\begin{array}{l}\text { Net mass of } \\
\text { dust on filter } \\
(g)\end{array}$ & $\begin{array}{c}\text { Net } \mu \mathrm{g} \mathrm{Pr} \\
\text { (total-avg blank) }\end{array}$ & $\begin{array}{l}\mu \mathrm{g} / \mathrm{g} \mathrm{Pr} \text { in } \\
\text { dust }\end{array}$ & $\begin{array}{l}\text { Flow rate } \\
\text { (CFM) }\end{array}$ & $\begin{array}{c}\text { Tracer } \\
\text { concentration } \\
(\mu \mathrm{g} / \mathrm{g} \operatorname{Pr} / \mathrm{CF}-\text { air })\end{array}$ & $\begin{array}{c}\text { Dust } \\
\text { concentration } \\
\text { (g/L-air) }\end{array}$ & $\begin{array}{c}\text { Tracer } \\
\text { concentration } \\
\text { ( } \mu \mathrm{g} / \mathrm{g} \mathrm{Pr} / \mathrm{CF} \text {-air) } \\
\text { background } \\
\text { corrected }\end{array}$ & $\begin{array}{l}\text { STD DEV } \\
\text { (2 sigma) }\end{array}$ & $\begin{array}{c}\text { Dust } \\
\text { concentration } \\
\text { (g/L-air) } \\
\text { background } \\
\text { corrected }\end{array}$ & $\begin{array}{c}\text { STD DEV } \\
\text { (2 sigma) }\end{array}$ \\
\hline 1 & & & & & & & & & & \\
\hline 2 & 0.2324 & 31.0307 & 133.5 & 15.1 & $9.70 \mathrm{E}-02$ & $5.54 \mathrm{E}-07$ & $9.40 \mathrm{E}-02$ & & 5.03E- -07 & \\
\hline 3 & 0.1892 & 38.4507 & 203.2 & 14.0 & 1.59E-01 & 4.87E-07 & $1.56 \mathrm{E}-01$ & & $4.35 \mathrm{E}-07$ & \\
\hline 4 & 0.2096 & 35.4082 & 168.9 & 16.5 & 1.13E-01 & 4.59E-07 & $1.10 \mathrm{E}-01$ & & 4.07E-07 & \\
\hline 5 & 0.1886 & 35.9607 & 190.7 & 14.5 & $1.44 \mathrm{E}-01$ & 4.68E-07 & 1.41E-01 & & $4.16 \mathrm{E}-07$ & \\
\hline 6 & 0.2174 & 53.3082 & 245.2 & 15.3 & $1.76 \mathrm{E}-01$ & 5.13E-07 & 1.73E-01 & & 4.62E-07 & \\
\hline 7 & 0.2058 & 48.2207 & 234.3 & 14.3 & $1.80 \mathrm{E}-01$ & $5.18 \mathrm{E}-07$ & $1.77 \mathrm{E}-01$ & & $4.66 \mathrm{E}-07$ & \\
\hline 8 & 0.1802 & 45.0907 & 250.2 & 15.7 & $1.75 \mathrm{E}-01$ & $4.14 \mathrm{E}-07$ & $1.72 \mathrm{E}-01$ & & 3.63E-07 & \\
\hline AVG & 0.2033 & 41.0671 & 203.71 & 15.07 & 1.49E-01 & 4.87E-07 & $1.46 \mathrm{E}-01$ & $\pm 6.11 \mathrm{E}-02$ & $4.36 \mathrm{E}-07$ & $\pm 8.50 \mathrm{E}-08$ \\
\hline
\end{tabular}


Test BASELINE RETRIEVAL \#2 (BR2)

TEMPERATURE:

SAMPLING TIME

$84 \mathrm{~F}$

BAROMETRIC PRESS: $841 \mathrm{mb}$

\begin{tabular}{|c|c|c|c|c|c|c|c|c|c|c|}
\hline Hi vol & $\begin{array}{c}\text { Net mass of } \\
\text { dust on filter } \\
\text { (g) }\end{array}$ & $\begin{array}{c}\text { Net } \underset{\text { g Pr }}{\text { (total-avg blank) }}\end{array}$ & $\begin{array}{l}\text { g/g Pr in } \\
\text { dust }\end{array}$ & $\begin{array}{l}\text { Fow rate } \\
\text { (CFM) }\end{array}$ & $\begin{array}{c}\text { Tracer } \\
\text { concentration } \\
\text { ( } \mathrm{g} / \mathrm{B} \text { Pr/CF-air })\end{array}$ & $\begin{array}{c}\text { Dust } \\
\text { concentration } \\
\text { (g/L-air) }\end{array}$ & $\begin{array}{c}\text { Tracer } \\
\text { concentration } \\
\text { ( g/g Pr/CF-air) } \\
\text { background } \\
\text { corrected }\end{array}$ & $\begin{array}{l}\text { STD DEV } \\
\text { (2 sigma) }\end{array}$ & $\begin{array}{l}\text { Dust } \\
\text { concentration } \\
\text { (g/L-air) } \\
\text { background } \\
\text { corrected }\end{array}$ & $\begin{array}{c}\text { STD DEV } \\
\text { (2 sigma) }\end{array}$ \\
\hline 1 & & & & & & & & & & \\
\hline 2 & & & & & & & & & & \\
\hline 3 & 0.5793 & 24.9707 & 37.0 & 13.2 & $9.36 \mathrm{E}-02$ & $4.81 \mathrm{E}-06$ & $9.06 \mathrm{E}-02$ & & 4.76E-06 & \\
\hline 4 & 0.6740 & 31.1682 & 53.8 & 13.4 & 1.34E-01 & $5.50 \mathrm{E}-06$ & $1.31 \mathrm{E}-01$ & & $5.45 \mathrm{E}-06$ & \\
\hline 5 & & & & & & & & & & \\
\hline & & & & & & & & & & \\
\hline & & & & & & & & & & \\
\hline 8 & 0.5964 & 29.9607 & 45.2 & 14.0 & $1.07 \mathrm{E}-01$ & 4.65E-06 & $1.04 \mathrm{E}-01$ & & $4.60 \mathrm{E}-06$ & \\
\hline AVG & 0.6166 & 28.6999 & 45.33 & 13.53 & $1.12 \mathrm{E}-01$ & $4.99 \mathrm{E}-06$ & $1.09 \mathrm{E}-01$ & $\pm 3.35 \mathrm{E}-02$ & $4.94 \mathrm{E}-06$ & $\pm 7.42 \mathrm{E}-07$ \\
\hline
\end{tabular}


DATA SUMMARY

(based on the averages of the data)

\begin{tabular}{|c|c|c|c|c|c|c|c|c|c|c|}
\hline Test ID & $\begin{array}{c}\text { Net mass of } \\
\text { dust on filter } \\
\text { (g) }\end{array}$ & $\begin{array}{c}\mathrm{Net} \\
\text { (total-avg blank) }\end{array}$ & $\begin{array}{r}\text { g/g Pr } \\
\text { in dust }\end{array}$ & $\begin{array}{l}\text { Flow rate } \\
\text { (CFM) }\end{array}$ & $\begin{array}{c}\text { Tracer } \\
\text { concentration } \\
\text { ( } \mathrm{g} / \mathrm{B} \mathrm{Pr} / \mathrm{CF} \text {-air })\end{array}$ & $\begin{array}{c}\text { Dust } \\
\text { concentration } \\
\text { (g/L-air) }\end{array}$ & $\begin{array}{c}\text { Tracer } \\
\text { concentration } \\
\text { ( } \mathrm{g} / \mathrm{g} \text { Pr/CF-air) } \\
\text { background } \\
\text { corrected }\end{array}$ & $\begin{array}{c}\text { STD DEV } \\
\text { (2 sigma) }\end{array}$ & $\begin{array}{c}\text { Dust } \\
\text { concentration } \\
\text { (g/L-air) } \\
\text { background } \\
\text { corrected }\end{array}$ & $\begin{array}{l}\text { STD DEV } \\
\text { (2 sigma) }\end{array}$ \\
\hline G-3 & 0.1043 & 0.7346 & 7.03 & 16.06 & $4.66 \mathrm{E}-03$ & 2.27E-07 & $1.63 \mathrm{E}-03$ & $\pm 1.41 \mathrm{E}-03$ & $1.76 \mathrm{E}-07$ & $\pm 6.29 \mathrm{E}-08$ \\
\hline G-5 & 0.0995 & 1.2079 & 10.81 & 16.30 & $3.85 \mathrm{E}-03$ & $1.30 \mathrm{E}-07$ & $8.23 \mathrm{E}-04$ & $\pm 2.37 \mathrm{E}-03$ & 7.83E-08 & $\pm 4.47 \mathrm{E}-08$ \\
\hline G.7 & 0.2190 & 1.8392 & 8.34 & 15.21 & $2.27 \mathrm{E}-03$ & $1.96 \mathrm{E}-07$ & $-7.59 \mathrm{E}-04$ & $\pm 7.49 \mathrm{E}-04$ & $1.44 \mathrm{E}-07$ & $\pm 8.32 \mathrm{E}-08$ \\
\hline BKG & 0.0274 & 0.1947 & 6.16 & 17.05 & $3.02 E-03$ & $5.13 \mathrm{E}-08$ & NA & & NA & \\
\hline BR-1 & 0.2359 & 2.5622 & 9.53 & 15.73 & $5.04 \mathrm{E}-03$ & $4.66 \mathrm{E}-07$ & 2.02E-03 & $\pm 6.95 \mathrm{E}-04$ & 4.15E-07 & $\pm 6.67 \mathrm{E}-08$ \\
\hline R-3 & 0.1014 & 170.50 & 1665.50 & 12.89 & $1.44 \mathrm{E}+00$ & 2.88E-07 & $1.44 \mathrm{E}+\infty 0$ & $\pm 6.29 \mathrm{E}-01$ & $2.36 \mathrm{E}-07$ & $\pm 8.75 \mathrm{E}-08$ \\
\hline$R-4$ & 0.0748 & 504.25 & 6359.38 & 13.55 & $8.11 E+00$ & 3.17E-07 & $8.11 E+00$ & $\pm 6.38 \mathrm{E}+00$ & $2.66 \mathrm{E}-07$ & $\pm 1.37 \mathrm{E}-07$ \\
\hline R-5 & 0.2033 & 41.067 & 203.71 & 15.07 & $1.49 \mathrm{E}-01$ & $4.87 \mathrm{E} 07$ & $1.46 \mathrm{E}-01$ & $\pm 6.11 \mathrm{E}-02$ & $4.36 \mathrm{E}-07$ & $\pm 8.50 \mathrm{E}-08$ \\
\hline BR-2 & 0.6166 & 28.700 & 45.33 & 13.53 & $1.12 \mathrm{E}-01$ & $4.99 \mathrm{E}-06$ & $1.09 \mathrm{E}-01$ & $\pm 3.35 \mathrm{E}-02$ & $4.94 \mathrm{E}-06$ & $\pm 7.42 \mathrm{E}-07$ \\
\hline
\end{tabular}

